\title{
Transient Receptor Potential channels (version 2019.4) in the IUPHAR/BPS Guide to Pharmacology Database
}

\author{
Nathaniel T. Blair ${ }^{1}$, Ingrid Carvacho ${ }^{1}$, Dipayan Chaudhuri ${ }^{1}$, David E. Clapham ${ }^{1}$, Paul DeCaen ${ }^{1}$, Markus Delling ${ }^{2}$, \\ Julia F. Doerner ${ }^{1}$, Lu Fan ${ }^{3}$, Kotdaji Ha², Sven E. Jordt³, David Julius ${ }^{4}$, Kristopher T Kahle', Boyi Liư ${ }^{3}$, David \\ McKemy $^{5}$, Bernd Nilius ${ }^{6}$, Elena Oancea ${ }^{7}$, Grzegorz Owsianik ${ }^{6}$, Antonio Riccio ${ }^{1}$, Rajan Sah ${ }^{8}$, Stephanie C. \\ Stotz $^{1}$, Jinbin Tian ${ }^{9}$, Dan Tong ${ }^{1}$, Charlotte Van den Eynde ${ }^{10}$, Joris Vriens ${ }^{10}$, Long-Jun Wu ${ }^{11}$, Haoxing Xu ${ }^{12}$, Lixia \\ Yue $^{13}$, Xiaoli Zhang ${ }^{12}$ and Michael X. Zhu ${ }^{9}$ \\ 1. Harvard Medical School, USA \\ 2. UCSF School of Medicine, USA \\ 3. Yale University, USA \\ 4. University of California San Francisco, USA \\ 5. University of Southern California, USA \\ 6. Katholieke Universiteit Leuven, Belgium \\ 7. Brown University, USA \\ 8. University of lowa, USA \\ 9. The University of Texas Health Science Center at Houston, USA \\ 10. KU Leuven, Belgium \\ 11. Rutgers University, USA \\ 12. University of Michigan, USA \\ 13. University of Connecticut School of Medicine, USA
}

\begin{abstract}
The TRP superfamily of channels (nomenclature as agreed by NC-IUPHAR [145, 915]), whose founder member is the Drosophila Trp channel, exists in mammals as six families; TRPC, TRPM, TRPV, TRPA, TRPP and TRPML based on amino acid homologies. TRP subunits contain six putative transmembrane domains and assemble as homo- or hetero-tetramers to form cation selective channels with diverse modes of activation and varied permeation properties (reviewed by [630]). Established, or potential, physiological functions of the individual members of the TRP families are discussed in detail in the recommended reviews and in a number of books [344, 589, 979, 216]. The established, or potential, involvement of TRP channels in disease is reviewed in $[384,588]$ and [591], together with a special edition of Biochemica et Biophysica Acta on the subject [588]. Additional disease related reviews, for pain [542], stroke [967], sensation and inflammation [843], itch [109], and airway disease [261, 896], are available. The pharmacology of most TRP channels has been advanced in recent years. Broad spectrum agents are listed in the tables along with more selective, or recently recognised, ligands that are flagged by the inclusion of a primary reference. See Rubaiy (2019) for a review of pharmacological tools for TRPC1/C4/C5 channels [692]. Most TRP channels are regulated by phosphoinostides such as $P$ tIns $(4,5) P_{2}$ although the effects reported are often complex, occasionally contradictory, and likely to be dependent upon experimental conditions, such as intracellular ATP levels (reviewed by [862, 592, 689]). Such regulation is generally not included in the tables. When thermosensitivity is mentioned, it refers specifically to a high Q10 of
\end{abstract}


gating, often in the range of 10-30, but does not necessarily imply that the channel's function is to act as a 'hot' or 'cold' sensor. In general, the search for TRP activators has led to many claims for temperature sensing, mechanosensation, and lipid sensing. All proteins are of course sensitive to energies of binding, mechanical force, and temperature, but the issue is whether the proposed input is within a physiologically relevant range resulting in a response.

TRPA (ankyrin) family

TRPA1 is the sole mammalian member of this group (reviewed by R46]). TRPA1 activation of sensory neurons contribute to nociception [356, 763, 516]. Pungent chemicals such as mustard oil (AITC), allicin, and cinnamaldehyde activate TRPA 1 by modification of free thiol groups of cysteine side chains, especially those located in its amino terminus [491, 47, 311, 493]. Alkenals with $\alpha, \beta$-unsaturated bonds, such as propenal (acrolein), butenal (crotylaldehyde), and 2-pentenal can react with free thiols via Michael addition and can activate TRPA1. However, potency appears to weaken as carbon chain length increases [21, 47]. Covalent modification leads to sustained activation of TRPA1. Chemicals including carvacrol, menthol, and local anesthetics reversibly activate TRPA 1 by non-covalent binding [364, 438, 923, 922]. TRPA 1 is not mechanosensitive under physiological conditions, but can be activated by cold temperatures [365, 175]. The electron cryo-EM structure of TRPA1 [639] indicates that it is a 6-TM homotetramer. Each subunit of the channel contains two short 'pore helices' pointing into the ion selectivity filter, which is big enough to allow permeation of partially hydrated $\mathrm{Ca}^{2+}$ ions.

TRPC (canonical) family

Members of the TRPC subfamily (reviewed by $239,673,14,4,79,382,638,55]$ ) fall into the subgroups outlined below. TRPC2 is a pseudogene in humans. It is generally accepted that all TRPC channels are activated downstream of $\mathrm{G}_{\mathrm{q} / 11}$-coupled receptors, or receptor tyrosine kinases (reviewed by $\left.661,814,915\right]$ ). A comprehensive listing of G-protein coupled receptors that activate TRPC channels is given in [4]. Heterooligomeric complexes of TRPC channels and their association with proteins to form signalling complexes are detailed in [14] and [383]. TRPC channels have frequently been proposed to act as store-operated channels (SOCs) (or compenents of mulimeric complexes that form SOCs), activated by depletion of intracellular calcium stores (reviewed by $[640,14,665,703,954,132,626,51,133]$ ). However, the weight of the evidence is that they are not directly gated by conventional store-operated mechanisms, as established for Stim-gated Orai channels. TRPC channels are not mechanically gated in physiologically relevant ranges of force. All members of the TRPC family are blocked by 2-APB and SKF96365 [295, 294]. Activation of TRPC channels by lipids is discussed by [55]. Important progress has been recently made in TRPC pharmacology [692, 529, 372, 87]. TRPC channels regulate a variety of physiological functions and are implicated in many human diseases [248, $56,759,879]$.

\section{TRPC1/C4/C5 subgroup}

TRPC1 alone may not form a functional ion channel [191]. TRPC4/C5 may be distinguished from other TRP channels by their potentiation by micromolar concentrations of La ${ }^{3+}$. TRPC2 is a pseudogene in humans, but in other mammals appears to be an ion channel localized to microvilli of the vomeronasal organ. It is required for normal sexual behavior in response to pheromones in mice. It may also function in the main olfactory epithelia in mice $[951,625,624,952,462,988,947]$.

\section{TRPC3/C6/C7 subgroup}

All members are activated by diacylglycerol independent of protein kinase C stimulation [295].

TRPM (melastatin) family

Members of the TRPM subfamily (reviewed by $230,294,640,978]$ ) fall into the five subgroups outlined below. 


\section{TRPM1/M3 subgroup}

In darkness, glutamate released by the photoreceptors and ON-bipolar cells binds to the metabotropic glutamate receptor 6 , leading to activation of Go. This results in the closure of TRPM1. When the photoreceptors are stimulated by light, glutamate release is reduced, and TRPM1 channels are more active, resulting in cell membrane depolarization. Human TRPM1 mutations are associated with congenital stationary night blindness (CSNB), whose patients lack rod function. TRPM1 is also found melanocytes. Isoforms of TRPM1 may present in melanocytes, melanoma, brain, and retina. In melanoma cells, TRPM1 is prevalent in highly dynamic intracellular vesicular structures [341, 609]. TRPM3 (reviewed by [615]) exists as multiple splice variants which differ significantly in their biophysical properties. TRPM3 is expressed in somatosensory neurons and may be important in development of heat hyperalgesia during inflammation (see review [803]). TRPM3 is frequently coexpressed with TRPA1 and TRPV1 in these neurons. TRPM3 is expressed in pancreatic beta cells as well as brain, pituitary gland, eye, kidney, and adipose tissue $[614,802]$. TRPM3 may contribute to the detection of noxious heat [870].

\section{TRPM2}

TRPM2 is activated under conditions of oxidative stress (respiratory burst of phagocytic cells) and ischemic conditions. However, the direct activators are $\operatorname{ADPR}(\mathrm{P})$ and calcium. As for many ion channels, $\mathrm{PIP}_{2}$ must also be present (reviewed by [935]). Numerous splice variants of TRPM2 exist which differ in their activation mechanisms [200]. The C-terminal domain contains a TRP motif, a coiled-coil region, and an enzymatic NUDT9 homologous domain. TRPM2 appears not to be activated by NAD, NAAD, or NAADP, but is directly activated by ADPRP (adenosine-5'-O-disphosphoribose phosphate) [827]. TRPM2 is involved in warmth sensation [24], and contributes to neurological diseases [61]. Recent study shows that 2'-deoxy-ADPR is an endogenous TRPM2 superagonist [231].

\section{TRPM4/5 subgroup}

TRPM4 and TRPM5 have the distinction within all TRP channels of being impermeable to $\mathrm{Ca}^{+}$[915]. A splice variant of TRPM4 (i.e.TRPM4b) and TRPM5 are molecular candidates for endogenous calcium-activated cation (CAN) channels [278]. TRPM4 is active in the late phase of repolarization of the cardiac ventricular action potential. TRPM4 deletion or knockout enhances beta adrenergic-mediated inotropy [507]. Mutations are associated with conduction defects [347, 507, 753]. TRPM4 has been shown to be an important regulator of $\mathrm{Ca}^{2+}$ entry in to mast cells [847] and dendritic cell migration [39]. TRPM5 in taste receptor cells of the tongue appears essential for the transduction of sweet, amino acid and bitter stimuli [460] TRPM5 contributes to the slow afterdepolarization of layer 5 neurons in mouse prefrontal cortex [439]. Both TRPM4 and TRPM5 are required transduction of taste stimuli [206].

\section{TRPM6/7 subgroup}

TRPM6 and 7 combine channel and enzymatic activities ('chanzymes'). These channels have the unusual property of permeation by divalent $\left(\mathrm{Ca}^{2+}, \mathrm{Mg}^{2+}, \mathrm{Zn}^{2+}\right)$ and monovalent cations, high single channel conductances, but overall extremely small inward conductance when expressed to the plasma membrane. They are inhibited by internal $\mathrm{Mg}^{2+}$ at $\sim 0.6 \mathrm{mM}$, around the free level of $\mathrm{Mg}^{2+}$ in cells. Whether they contribute to $\mathrm{Mg}^{2+}$ homeostasis is a contentious issue. When either gene is deleted in mice, the result is embryonic lethality. The C-terminal kinase region is cleaved under unknown stimuli, and the kinase phosphorylates nuclear histones. TRPM7 is responsible for oxidant- induced $\mathrm{Zn}^{2+}$ release from intracellular vesicles [3] and contributes to intestinal mineral absorption essential for postnatal survival [532].

\section{TRPM8}

Is a channel activated by cooling and pharmacological agents evoking a 'cool' sensation and participates in the thermosensation of cold temperatures $[50,147,186]$ reviewed by $[864,481,391,556]$.

TRPML (mucolipin) family 
The TRPML family $[676,964,670,926,156]$ consists of three mammalian members (TRPML1-3). TRPML channels are probably restricted to intracellular vesicles and mutations in the gene (MCOLN1) encoding TRPML1 (mucolipin-1) cause the neurodegenerative disorder mucolipidosis type IV (MLIV) in man. TRPML1 is a cation selective ion channel that is important for sorting/transport of endosomes in the late endocytotic pathway and specifically, fission from late endosome-lysosome hybrid vesicles and lysosomal exocytosis [704]. TRPML2 and TRPML3 show increased channel activity in low extracellular sodium and are activated by similar small molecules [270]. A naturally occurring gain of function mutation in TRPML3 (.e. A419P) results in the varitint waddler (Va) mouse phenotype (reviewed by [676, 593]).

TRPP (polycystin) family

The TRPP family (reviewed by [179, 177, 252, 905, 320]) or PKD2 family is comprised of PKD2 (PC2), PKD2L1 (PC2L1), PKD2L2 (PC2L2), which have been renamed TRPP1, TRPP2 and TRPP3, respectively [915]. It should also be noted that the nomenclature of PC2 was TRPP2 in old literature. However, PC2 has been uniformed to be called TRPP2 [293]. PKD2 family channels are clearly distinct from the PKD1 family, whose function is unknown. PKD1 and PKD2 form a hetero-oligomeric complex with a 1:3 ratio. [775]. Although still being sorted out, TRPP family members appear to be 6TM spanning nonselective cation channels.

TRPV (vanilloid) family

Members of the TRPV family (reviewed by [849]) can broadly be divided into the non-selective cation channels, TRPV1-4 and the more calcium selective channels TRPV5 and TRPV6.

\section{TRPV1-V4 subfamily}

TRPV1 is involved in the development of thermal hyperalgesia following inflammation and may contribute to the detection of noxius heat (reviewed by $[660,756,786])$. Numerous splice variants of TRPV1 have been described, some of which modulate the activity of TRPV1, or act in a dominant negative manner when coexpressed with TRPV1 [722]. The pharmacology of TRPV1 channels is discussed in detail in 280] and [868]. TRPV2 is probably not a thermosensor in man [635], but has recently been implicated in innate immunity [469]. TRPV3 and TRPV4 are both thermosensitive. There are claims that TRPV4 is also mechanosensitive, but this has not been established to be within a physiological range in a native environment [106, 454].

\section{TRPV5/V6 subfamily}

TRPV5 and TRPV6 are highly expressed in placenta, bone, and kidney. Under physiological conditions, TRPV5 and TRPV 6 are calcium selective channels involved in the absorption and reabsorption of calcium across intestinal and kidney tubule epithelia (reviewed by [901, 168, 558, 227]).

\section{Contents}

This is a citation summary for Transient Receptor Potential channels in the Guide to Pharmacology database (GtoPdb). It exists purely as an adjunct to the database to facilitate the recognition of citations to and from the database by citation analyzers. Readers will almost certainly want to visit the relevant sections of the database which are given here under database links.

GtoPdb is an expert-driven guide to pharmacological targets and the substances that act on them. GtoPdb is a reference work which is most usefully represented as an on-line database. As in any publication this work should be appropriately cited, and the papers it cites should also be recognized. This document provides a citation for the relevant parts of the database, and also provides a reference list for the research cited by those parts.

Please note that the database version for the citations given in GtoPdb are to the most recent preceding version in which the family or its subfamilies and targets were substantially changed. The links below are to the current version. If you need to consult the cited version, rather than the most recent version, please contact the GtoPdb 
curators.

\section{Database links}

Transient Receptor Potential channels

http://www.guidetopharmacology.org/GRAC/FamilyDisplayForward?familyld=78

Introduction to Transient Receptor Potential channels

http://www.guidetopharmacology.org/GRAC/FamilylntroductionForward?familyld=78

Channels and Subunits

TRPA1

http://www.guidetopharmacology.org/GRAC/ObjectDisplayForward?objectld=485

TRPC1

http://www.guidetopharmacology.org/GRAC/ObjectDisplayForward?objectld=486

TRPC2

http://www.guidetopharmacology.org/GRAC/ObjectDisplayForward?objectld=487

TRPC3

http://www.guidetopharmacology.org/GRAC/ObjectDisplayForward?objectld=488 TRPC4

http://www.guidetopharmacology.org/GRAC/ObjectDisplayForward?objectld=489 TRPC5

http://www.guidetopharmacology.org/GRAC/ObjectDisplayForward?objectld=490 TRPC6

http://www.guidetopharmacology.org/GRAC/ObjectDisplayForward?objectld=491 TRPC7

http://www.guidetopharmacology.org/GRAC/ObjectDisplayForward?objectld=492 TRPM1

http://www.guidetopharmacology.org/GRAC/ObjectDisplayForward?objectld=493 TRPM2

http://www.guidetopharmacology.org/GRAC/ObjectDisplayForward?objectld=494 TRPM3

http://www.guidetopharmacology.org/GRAC/ObjectDisplayForward?objectld=495 TRPM4

http://www.guidetopharmacology.org/GRAC/ObjectDisplayForward?objectld=496 TRPM5

http://www.guidetopharmacology.org/GRAC/ObjectDisplayForward?objectld=497 TRPM6

http://www.guidetopharmacology.org/GRAC/ObjectDisplayForward?objectld=498 TRPM7

http://www.guidetopharmacology.org/GRAC/ObjectDisplayForward?objectld=499 TRPM8

http://www.guidetopharmacology.org/GRAC/ObjectDisplayForward?objectld=500

TRPML1

http://www.guidetopharmacology.org/GRAC/ObjectDisplayForward?objectld=501 TRPML2

http://www.guidetopharmacology.org/GRAC/ObjectDisplayForward?objectld=502 TRPML3

http://www.guidetopharmacology.org/GRAC/ObjectDisplayForward?objectld=503 TRPP1

http://www.guidetopharmacology.org/GRAC/ObjectDisplayForward?objectld=504 TRPP2

http://www.guidetopharmacology.org/GRAC/ObjectDisplayForward?objectld=505 


\section{TRPP3}

http://www.guidetopharmacology.org/GRAC/ObjectDisplayForward?objectld=506 TRPV1

http://www.guidetopharmacology.org/GRAC/ObjectDisplayForward?objectld=507 TRPV2

http://www.guidetopharmacology.org/GRAC/ObjectDisplayForward?objectld=508 TRPV3

http://www.guidetopharmacology.org/GRAC/ObjectDisplayForward?objectld=509 TRPV4

http://www.guidetopharmacology.org/GRAC/ObjectDisplayForward?objectld=510 TRPV5

http://www.guidetopharmacology.org/GRAC/ObjectDisplayForward?objectld=511 TRPV6

http://www.guidetopharmacology.org/GRAC/ObjectDisplayForward?objectld=512

\section{References}

1. Aarts M, lihara K, Wei WL, Xiong ZG, Arundine M, Cerwinski W, MacDonald JF and Tymianski M. (2003) A key role for TRPM7 channels in anoxic neuronal death. Cell 115: 863-77 [PMID:14697204]

2. Aarts MM and Tymianski M. (2005) TRPMs and neuronal cell death.Pflugers Arch. 451: 243-9 [PMID:16044308]

3. Abiria SA, Krapivinsky G, Sah R, Santa-Cruz AG, Chaudhuri D, Zhang J, Adstamongkonkul P, DeCaen $\mathrm{PG}$ and Clapham DE. (2017) TRPM7 senses oxidative stress to release $\mathrm{Zn}^{2+}$ from unique intracellular vesicles. Proc. Natl. Acad. Sci. U.S.A. 114: E6079-E6088 [PMID:28696294]

4. Abramowitz $\mathrm{J}$ and Birnbaumer L. (2009) Physiology and pathophysiology of canonical transient receptor potential channels. FASEB J. 23: 297-328 [PMID:18940894]

5. Adebiyi A, Zhao G, Narayanan D, Thomas-Gatewood CM, Bannister JP and Jaggar JH. (2010) Isoformselective physical coupling of TRPC3 channels to IP3 receptors in smooth muscle cells regulates arterial contractility. Circ. Res. 106: 1603-12 [PMID:20378853]

6. Ahmed MK, Takumida M, Ishibashi T, Hamamoto T and Hirakawa K. (2009) Expression of transient receptor potential vanilloid (TRPV) families 1, 2, 3 and 4 in the mouse olfactory epithelium. Rhinology 47: 242-7 [PMID:19839244]

7. Akbulut Y, Gaunt HJ, Muraki K, Ludlow MJ, Amer MS, Bruns A, Vasudev NS, Radtke L, Willot M and Hahn $S$ et al.. (2015) (-)-Englerin A is a potent and selective activator of TRPC4 and TRPC5 calcium channels. Angew. Chem. Int. Ed. Engl.54: 3787-91 [PMID:25707820]

8. Akopian AN, Ruparel NB, Patwardhan A and Hargreaves KM. (2008) Cannabinoids desensitize capsaicin and mustard oil responses in sensory neurons via TRPA1 activation. J. Neurosci. 28: 1064-75 [PMID:18234885]

9. Alessandri-Haber N, Dina OA, Joseph EK, Reichling D and Levine JD. (2006) A transient receptor potential vanilloid 4-dependent mechanism of hyperalgesia is engaged by concerted action of inflammatory mediators. J. Neurosci. 26: 3864-74 [PMID:16597741]

10. Alessandri-Haber N, Yeh JJ, Boyd AE, Parada CA, Chen X, Reichling DB and Levine JD. (2003) Hypotonicity induces TRPV4-mediated nociception in rat. Neuron 39: 497-511 [PMID:12895423]

11. Alfonso S, Benito O, Alicia S, Angélica Z, Patricia G, Diana K, Vaca L and Luis V. (2008) Regulation of the cellular localization and function of human transient receptor potential channel 1 by other members of the TRPC family. Cell Calcium 43: 375-87 [PMID:17850866]

12. Almeida MC, Hew-Butler T, Soriano RN, Rao S, Wang W, Wang J, Tamayo N, Oliveira DL, Nucci TB and Aryal P et al.. (2012) Pharmacological blockade of the cold receptor TRPM8 attenuates autonomic and behavioral cold defenses and decreases deep body temperature. J. Neurosci. 32: 2086-99 [PMID:22323721]

13. Alvarez DF, King JA, Weber D, Addison E, Liedtke W and Townsley MI. (2006) Transient receptor 
potential vanilloid 4-mediated disruption of the alveolar septal barrier: a novel mechanism of acute lung injury. Circ. Res. 99: 988-95 [PMID:17008604]

14. Ambudkar IS and Ong HL. (2007) Organization and function of TRPC channelosomes.Pflugers Arch. 455: 187-200 [PMID:17486362]

15. Ambudkar IS, Ong HL, Liu X, Bandyopadhyay BC, Bandyopadhyay B and Cheng KT. (2007) TRPC1: the link between functionally distinct store-operated calcium channels. Cell Calcium 42: 213-23 [PMID:17350680]

16. Andersson DA, Chase HW and Bevan S. (2004) TRPM8 activation by menthol, icilin, and cold is differentially modulated by intracellular $\mathrm{pH}$. J. Neurosci. 24: 5364-9 [PMID:15190109]

17. Andersson DA, Gentry C, Alenmyr L, Killander D, Lewis SE, Andersson A, Bucher B, Galzi JL, Sterner O and Bevan $S$ et al.. (2011) TRPA1 mediates spinal antinociception induced by acetaminophen and the cannabinoid $\Delta(9)$-tetrahydrocannabiorcol. Nat Commun 2: 551 [PMID:22109525]

18. Andersson DA, Gentry C, Moss $S$ and Bevan S. (2009) Clioquinol and pyrithione activate TRPA1 by increasing intracellular Zn2+. Proc. Natl. Acad. Sci. U.S.A. 106: 8374-9 [PMID:19416844]

19. Andersson DA, Gentry C, Moss $S$ and Bevan S. (2008) Transient receptor potential A1 is a sensory receptor for multiple products of oxidative stress. J. Neurosci. 28: 2485-94 [PMID:18322093]

20. Andrade EL, Forner S, Bento AF, Leite DF, Dias MA, Leal PC, Koepp J and Calixto JB. (2011) TRPA1 receptor modulation attenuates bladder overactivity induced by spinal cord injury. Am. J. Physiol. Renal Physiol. 300: F1223-34 [PMID:21367919]

21. Andrè E, Campi B, Materazzi S, Trevisani M, Amadesi S, Massi D, Creminon C, Vaksman N, Nassini R and Civelli $\mathrm{M}$ et al.. (2008) Cigarette smoke-induced neurogenic inflammation is mediated by alpha,betaunsaturated aldehydes and the TRPA1 receptor in rodents. J. Clin. Invest. 118: 2574-82 [PMID:18568077]

22. Andrè E, Gatti R, Trevisani M, Preti D, Baraldi PG, Patacchini R and Geppetti P. (2009) Transient receptor potential ankyrin receptor 1 is a novel target for pro-tussive agents. Br. J. Pharmacol. 158: 1621-8 [PMID:19845671]

23. Aoyagi K, Ohara-Imaizumi M, Nishiwaki C, Nakamichi Y and Nagamatsu S. (2010) Insulin/phosphoinositide 3-kinase pathway accelerates the glucose-induced first-phase insulin secretion through TrpV2 recruitment in pancreatic $\beta$-cells. Biochem. J. 432: 375-86 [PMID:20854263]

24. Appendino G, De Petrocellis L, Trevisani M, Minassi A, Daddario N, Moriello AS, Gazzieri D, Ligresti A, Campi B and Fontana G et al.. (2005) Development of the first ultra-potent "capsaicinoid" agonist at transient receptor potential vanilloid type 1 (TRPV1) channels and its therapeutic potential. J. Pharmacol. Exp. Ther. 312: 561-70 [PMID:15356216]

25. Asakawa M, Yoshioka T, Matsutani T, Hikita I, Suzuki M, Oshima I, Tsukahara K, Arimura A, Horikawa T and Hirasawa T et al.. (2006) Association of a mutation in TRPV3 with defective hair growth in rodents J. Invest. Dermatol. 126: 2664-72 [PMID:16858425]

26. Assas BM, Wakid MH, Zakai HA, Miyan JA and Pennock JL. (2016) Transient receptor potential vanilloid 1 expression and function in splenic dendritic cells: a potential role in immune homeostasis. Immunology 147: 292-304 [PMID:26643862]

27. Audo I, Kohl S, Leroy BP, Munier FL, Guillonneau X, Mohand-Saïd S, Bujakowska K, Nandrot EF, Lorenz $\mathrm{B}$ and Preising $\mathrm{M}$ et al.. (2009) TRPM1 is mutated in patients with autosomal-recessive complete congenital stationary night blindness. Am. J. Hum. Genet. 85: 720-9 [PMID:19896113]

28. Auer-Grumbach M, Olschewski A, Papić L, Kremer H, McEntagart ME, Uhrig S, Fischer C, Fröhlich E, Bálint $Z$ and Tang B et al.. (2010) Alterations in the ankyrin domain of TRPV4 cause congenital distal SMA, scapuloperoneal SMA and HMSN2C. Nat. Genet. 42: 160-4 [PMID:20037588]

29. Balzer M, Lintschinger B and Groschner K. (1999) Evidence for a role of Trp proteins in the oxidative stress-induced membrane conductances of porcine aortic endothelial cells. Cardiovasc. Res. 42: 543-9 [PMID:10533589]

30. Bandell M, Story GM, Hwang SW, Viswanath V, Eid SR, Petrus MJ, Earley TJ and Patapoutian A. (2004) Noxious cold ion channel TRPA1 is activated by pungent compounds and bradykinin. Neuron 41: 849-57 [PMID:15046718] 
31. Bandyopadhyay BC, Swaim WD, Liu X, Redman RS, Patterson RL and Ambudkar IS. (2005) Apical localization of a functional TRPC3/TRPC6-Ca2+-signaling complex in polarized epithelial cells. Role in apical Ca2+ influx. J. Biol. Chem. 280: 12908-16 [PMID:15623527]

32. Bang S, Kim KY, Yoo S, Kim YG and Hwang SW. (2007) Transient receptor potential A1 mediates acetaldehyde-evoked pain sensation. Eur. J. Neurosci. 26: 2516-23 [PMID:17970723]

33. Bang S, Kim KY, Yoo S, Lee SH and Hwang SW. (2007) Transient receptor potential V2 expressed in sensory neurons is activated by probenecid. Neurosci. Lett. 425: 120-5 [PMID:17850966]

34. Bang S, Yoo S, Yang TJ, Cho H and Hwang SW. (2012) 17(R)-resolvin D1 specifically inhibits transient receptor potential ion channel vanilloid 3 leading to peripheral antinociception. Br. J. Pharmacol. 165: 68392 [PMID:21718307]

35. Bang S, Yoo S, Yang TJ, Cho H and Hwang SW. (2011) Isopentenyl pyrophosphate is a novel antinociceptive substance that inhibits TRPV3 and TRPA1 ion channels. Pain 152: 1156-64 [PMID:21353389]

36. Bang S, Yoo S, Yang TJ, Cho H and Hwang SW. (2010) Farnesyl pyrophosphate is a novel painproducing molecule via specific activation of TRPV3. J. Biol. Chem. 285: 19362-71 [PMID:20395302]

37. Bang S, Yoo S, Yang TJ, Cho H, Kim YG and Hwang SW. (2010) Resolvin D1 attenuates activation of sensory transient receptor potential channels leading to multiple anti-nociception. Br. J. Pharmacol. 161: 707-20 [PMID:20880407]

38. Baraldi PG, Preti D, Materazzi S and Geppetti P. (2010) Transient receptor potential ankyrin 1 (TRPA1) channel as emerging target for novel analgesics and anti-inflammatory agents. J. Med. Chem. 53: 5085107 [PMID:20356305]

39. Barbet G, Demion M, Moura IC, Serafini N, Léger T, Vrtovsnik F, Monteiro RC, Guinamard R, Kinet JP and Launay P. (2008) The calcium-activated nonselective cation channel TRPM4 is essential for the migration but not the maturation of dendritic cells. Nat. Immunol. 9: 1148-56 [PMID:18758465]

40. Bargal R, Avidan N, Ben-Asher E, Olender Z, Zeigler M, Frumkin A, Raas-Rothschild A, Glusman G, Lancet $D$ and Bach G. (2000) Identification of the gene causing mucolipidosis type IV. Nat. Genet. 26: 11823 [PMID:10973263]

41. Bargal R and Bach G. (1997) Mucolipidosis type IV: abnormal transport of lipids to lysosomesJ. Inherit. Metab. Dis. 20: 625-32 [PMID:9323557]

42. Bari MR, Akbar S, Eweida M, Kühn FJ, Gustafsson AJ, Lückhoff A and Islam MS. (2009) H2O2-induced $\mathrm{Ca} 2+$ influx and its inhibition by $\mathrm{N}$-(p-amylcinnamoyl) anthranilic acid in the beta-cells: involvement of TRPM2 channels. J. Cell. Mol. Med. 13: 3260-7 [PMID:19382906]

43. Barley NF, Howard A, O'Callaghan D, Legon S and Walters JR. (2001) Epithelial calcium transporter expression in human duodenum. Am. J. Physiol. Gastrointest. Liver Physiol. 280: G285-90 [PMID:11208552]

44. Barnhill JC, Stokes AJ, Koblan-Huberson M, Shimoda LM, Muraguchi A, Adra CN and Turner H. (2004) RGA protein associates with a TRPV ion channel during biosynthesis and trafficking. J. Cell. Biochem. 91: 808-20 [PMID:14991772]

45. Barrière DA, Rieusset J, Chanteranne D, Busserolles J, Chauvin MA, Chapuis L, Salles J, Dubray C and Morio B. (2012) Paclitaxel therapy potentiates cold hyperalgesia in streptozotocin-induced diabetic rats through enhanced mitochondrial reactive oxygen species production and TRPA1 sensitization. Pain 153: 553-61 [PMID:22177224]

46. Barro-Soria R, Stindl J, Müller C, Foeckler R, Todorov V, Castrop H and Strauß O. (2012) Angiotensin-2mediated $\mathrm{Ca} 2+$ signaling in the retinal pigment epithelium: role of angiotensin-receptor-associated-protein and TRPV2 channel. PLoS ONE 7: e49624 [PMID:23185387]

47. Bautista DM, Jordt SE, Nikai T, Tsuruda PR, Read AJ, Poblete J, Yamoah EN, Basbaum AI and Julius D. (2006) TRPA1 mediates the inflammatory actions of environmental irritants and proalgesic agents. Cell 124: 1269-82 [PMID:16564016]

48. Bautista DM, Movahed P, Hinman A, Axelsson HE, Sterner O, Högestätt ED, Julius D, Jordt SE and Zygmunt PM. (2005) Pungent products from garlic activate the sensory ion channel TRPA1. Proc. Natl. 
Acad. Sci. U.S.A. 102: 12248-52 [PMID:16103371]

49. Bautista DM, Pellegrino M and Tsunozaki M. (2013) TRPA1: A gatekeeper for inflammation.Annu. Rev. Physiol. 75: 181-200 [PMID:23020579]

50. Bautista DM, Siemens J, Glazer JM, Tsuruda PR, Basbaum AI, Stucky CL, Jordt SE and Julius D. (2007) The menthol receptor TRPM8 is the principal detector of environmental cold. Nature 448: 204-8 [PMID:17538622]

51. Bavencoffe A, Zhu MX and Tian JB. (2017) New Aspects of the Contribution of ER to SOCE Regulation: TRPC Proteins as a Link Between Plasma Membrane Ion Transport and Intracellular $\mathrm{Ca}^{2+}$ Stores. Adv. Exp. Med. Biol. 993: 239-255 [PMID:28900918]

52. Becerra A, Echeverría C, Varela D, Sarmiento D, Armisén R, Nuñez-Villena F, Montecinos M and Simon F. (2011) Transient receptor potential melastatin 4 inhibition prevents lipopolysaccharide-induced endothelial cell death. Cardiovasc. Res. 91: 677-84 [PMID:21565835]

53. Beck A, Kolisek M, Bagley LA, Fleig A and Penner R. (2006) Nicotinic acid adenine dinucleotide phosphate and cyclic ADP-ribose regulate TRPM2 channels in T lymphocytes. FASEB J. 20: 962-4 [PMID:16585058]

54. Becker EB, Oliver PL, Glitsch MD, Banks GT, Achilli F, Hardy A, Nolan PM, Fisher EM and Davies KE. (2009) A point mutation in TRPC3 causes abnormal Purkinje cell development and cerebellar ataxia in moonwalker mice. Proc. Natl. Acad. Sci. U.S.A. 106: 6706-11 [PMID:19351902]

55. Beech DJ. (2012) Integration of transient receptor potential canonical channels with lipids Acta Physiol (Oxf) 204: 227-37 [PMID:21624095]

56. Beech DJ. (2013) Characteristics of transient receptor potential canonical calcium-permeable channels and their relevance to vascular physiology and disease. Circ. J. 77: 570-9 [PMID:23412755]

57. Behrendt HJ, Germann T, Gillen C, Hatt H and Jostock R. (2004) Characterization of the mouse coldmenthol receptor TRPM8 and vanilloid receptor type-1 VR1 using a fluorometric imaging plate reader (FLIPR) assay. Br. J. Pharmacol. 141: 737-45 [PMID:14757700]

58. Beis D, Schwarting RK and Dietrich A. (2011) Evidence for a supportive role of classical transient receptor potential 6 (TRPC6) in the exploration behavior of mice. Physiol. Behav. 102: 245-50 [PMID:21059368]

59. Bellone RR, Forsyth G, Leeb T, Archer S, Sigurdsson S, Imsland F, Mauceli E, Engensteiner M, Bailey E and Sandmeyer $L$ et al.. (2010) Fine-mapping and mutation analysis of TRPM1: a candidate gene for leopard complex (LP) spotting and congenital stationary night blindness in horses. Brief Functional Genomics 9: 193-207 [PMID:20353955]

60. Bellono NW, Kammel LG, Zimmerman AL and Oancea E. (2013) UV light phototransduction activates transient receptor potential A1 ion channels in human melanocytes. Proc. Natl. Acad. Sci. U.S.A. 110: 2383-8 [PMID:23345429]

61. Belrose JC and Jackson MF. (2018) TRPM2: a candidate therapeutic target for treating neurological diseases. Acta Pharmacol. Sin. 39: 722-732 [PMID:29671419]

62. Belrose JC, Xie YF, Gierszewski LJ, MacDonald JF and Jackson MF. (2012) Loss of glutathione homeostasis associated with neuronal senescence facilitates TRPM2 channel activation in cultured hippocampal pyramidal neurons. Mol Brain 5: 11 [PMID:22487454]

63. Benfenati V, Amiry-Moghaddam M, Caprini M, Mylonakou MN, Rapisarda C, Ottersen OP and Ferroni S. (2007) Expression and functional characterization of transient receptor potential vanilloid-related channel 4 (TRPV4) in rat cortical astrocytes. Neuroscience 148: 876-92 [PMID:17719182]

64. Berbey C, Weiss N, Legrand C and Allard B. (2009) Transient receptor potential canonical type 1 (TRPC1) operates as a sarcoplasmic reticulum calcium leak channel in skeletal muscle. J. Biol. Chem. 284: 3638794 [PMID:19875453]

65. Bertin S, Aoki-Nonaka Y, de Jong PR, Nohara LL, Xu H, Stanwood SR, Srikanth S, Lee J, To K and Abramson $L$ et al.. (2014) The ion channel TRPV1 regulates the activation and proinflammatory properties of CD4+ T cells. Nat. Immunol. 15: 1055-1063 [PMID:25282159]

66. Bertin S, de Jong PR, Jefferies WA and Raz E. (2014) Novel immune function for the TRPV1 channel in T lymphocytes. Channels (Austin) 8: 479-80 [PMID:25530461] 
67. Bessac BF and Jordt SE. (2010) Sensory detection and responses to toxic gases: mechanisms, health effects, and countermeasures. Proc Am Thorac Soc 7: 269-77 [PMID:20601631]

68. Bessac BF, Sivula M, von Hehn CA, Caceres AI, Escalera J and Jordt SE. (2009) Transient receptor potential ankyrin 1 antagonists block the noxious effects of toxic industrial isocyanates and tear gases. FASEB J. 23: 1102-14 [PMID:19036859]

69. Bessac BF, Sivula M, von Hehn CA, Escalera J, Cohn L and Jordt SE. (2008) TRPA1 is a major oxidant sensor in murine airway sensory neurons. J. Clin. Invest. 118: 1899-910 [PMID:18398506]

70. Bezençon C, le Coutre J and Damak S. (2007) Taste-signaling proteins are coexpressed in solitary intestinal epithelial cells. Chem. Senses 32: $41-9$ [PMID:17030556]

71. Bhave G, Hu HJ, Glauner KS, Zhu W, Wang H, Brasier DJ, Oxford GS and Gereau 4th RW. (2003) Protein kinase $\mathrm{C}$ phosphorylation sensitizes but does not activate the capsaicin receptor transient receptor potential vanilloid 1 (TRPV1). Proc. Natl. Acad. Sci. U.S.A. 100: 12480-5 [PMID:14523239]

72. Bhunia AK, Piontek K, Boletta A, Liu L, Qian F, Xu PN, Germino FJ and Germino GG. (2002) PKD1 induces p21(waf1) and regulation of the cell cycle via direct activation of the JAK-STAT signaling pathway in a process requiring PKD2. Cell 109: 157-68 [PMID:12007403]

73. Bianchi B, Smith PA and Abriel H. (2018) The ion channel TRPM4 in murine experimental autoimmune encephalomyelitis and in a model of glutamate-induced neuronal degeneration. Mol Brain 11: 41 [PMID:29996905]

74. Bianchi BR, El Kouhen R, Neelands TR, Lee CH, Gomtsyan A, Raja SN, Vaidyanathan SN, Surber B, McDonald HA and Surowy CS et al.. (2007) [3H]A-778317 [1-((R)-5-tert-butyl-indan-1-yl)-3-isoquinolin-5-ylurea]: a novel, stereoselective, high-affinity antagonist is a useful radioligand for the human transient receptor potential vanilloid-1 (TRPV1) receptor. J. Pharmacol. Exp. Ther. 323: 285-93 [PMID:17660385]

75. Bianco SD, Peng JB, Takanaga H, Suzuki Y, Crescenzi A, Kos CH, Zhuang L, Freeman MR, Gouveia CH and Wu J et al.. (2007) Marked disturbance of calcium homeostasis in mice with targeted disruption of the Trpv6 calcium channel gene. J. Bone Miner. Res. 22: 274-85 [PMID:17129178]

76. Binder A, May D, Baron R, Maier C, Tölle TR, Treede RD, Berthele A, Faltraco F, Flor H and Gierthmühlen $\mathrm{J}$ et al.. (2011) Transient receptor potential channel polymorphisms are associated with the somatosensory function in neuropathic pain patients. PLoS ONE 6: e17387 [PMID:21468319]

77. Birder L, Kullmann FA, Lee H, Barrick S, de Groat W, Kanai A and Caterina M. (2007) Activation of urothelial transient receptor potential vanilloid 4 by 4 alpha-phorbol 12,13-didecanoate contributes to altered bladder reflexes in the rat. J. Pharmacol. Exp. Ther. 323: 227-35 [PMID:17636010]

78. Birder LA, Kanai AJ, de Groat WC, Kiss S, Nealen ML, Burke NE, Dineley KE, Watkins S, Reynolds IJ and Caterina MJ. (2001) Vanilloid receptor expression suggests a sensory role for urinary bladder epithelial cells. Proc. Natl. Acad. Sci. U.S.A. 98: 13396-401 [PMID:11606761]

79. Birnbaumer L. (2009) The TRPC class of ion channels: a critical review of their roles in slow, sustained increases in intracellular $\mathrm{Ca}(2+)$ concentrations. Annu. Rev. Pharmacol. Toxicol. 49: 395-426 [PMID:19281310]

80. Birrell MA, Belvisi MG, Grace M, Sadofsky L, Faruqi S, Hele DJ, Maher SA, Freund-Michel V and Morice AH. (2009) TRPA1 agonists evoke coughing in guinea pig and human volunteers. Am. J. Respir. Crit. Care Med. 180: 1042-7 [PMID:19729665]

81. Blair NT, Kaczmarek JS and Clapham DE. (2009) Intracellular calcium strongly potentiates agonistactivated TRPC5 channels. J. Gen. Physiol. 133: 525-46 [PMID:19398778]

82. Blum CA, Caldwell T, Zheng X, Bakthavatchalam R, Capitosti S, Brielmann H, De Lombaert S, Kershaw MT, Matson D and Krause JE et al.. (2010) Discovery of novel 6,6-heterocycles as transient receptor potential vanilloid (TRPV1) antagonists. J. Med. Chem. 53: 3330-48 [PMID:20307063]

83. Boels K, Glassmeier G, Herrmann D, Riedel IB, Hampe W, Kojima I, Schwarz JR and Schaller HC. (2001) The neuropeptide head activator induces activation and translocation of the growth-factor-regulated $\mathrm{Ca}(2+)$-permeable channel GRC. J. Cell. Sci. 114: 3599-606 [PMID:11707512]

84. Bohlen CJ, Priel A, Zhou S, King D, Siemens J and Julius D. (2010) A bivalent tarantula toxin activates the capsaicin receptor, TRPV1, by targeting the outer pore domain. Cell 141: 834-45 [PMID:20510930] 
85. Boisseau S, Kunert-Keil C, Lucke S and Bouron A. (2009) Heterogeneous distribution of TRPC proteins in the embryonic cortex. Histochem. Cell Biol. 131: 355-63 [PMID:18989690]

86. Bollimuntha S, Ebadi M and Singh BB. (2006) TRPC1 protects human SH-SY5Y cells against salsolinolinduced cytotoxicity by inhibiting apoptosis. Brain Res. 1099: 141-9 [PMID:16765919]

87. Bon RS and Beech DJ. (2013) In pursuit of small molecule chemistry for calcium-permeable non-selective TRPC channels -- mirage or pot of gold? Br. J. Pharmacol. 170: 459-74 [PMID:23763262]

88. Bonet IJ, Fischer L, Parada CA and Tambeli CH. (2013) The role of transient receptor potential A 1 (TRPA1) in the development and maintenance of carrageenan-induced hyperalgesia. Neuropharmacology 65: 206-12 [PMID:23098993]

89. Borbíró I, Lisztes E, Tóth BI, Czifra G, Oláh A, Szöllosi AG, Szentandrássy N, Nánási PP, Péter Z and Paus $R$ et al.. (2011) Activation of transient receptor potential vanilloid-3 inhibits human hair growth $J$. Invest. Dermatol. 131: 1605-14 [PMID:21593771]

90. Boulay G. (2002) $\mathrm{Ca}(2+)$-calmodulin regulates receptor-operated $\mathrm{Ca}(2+)$ entry activity of TRPC6 in HEK293 cells. Cell Calcium 32: 201-7 [PMID:12379180]

91. Boulay G, Zhu X, Peyton M, Jiang M, Hurst R, Stefani E and Birnbaumer L. (1997) Cloning and expression of a novel mammalian homolog of Drosophila transient receptor potential (Trp) involved in calcium entry secondary to activation of receptors coupled by the Gq class of G protein. J. Biol. Chem. 272: 29672-80 [PMID:9368034]

92. Boulay ME and Boulet LP. (2002) Lower airway inflammatory responses to repeated very-low-dose allergen challenge in allergic rhinitis and asthma. Clin. Exp. Allergy 32: 1441-7 [PMID:12372123]

93. Bowen CV, DeBay D, Ewart HS, Gallant P, Gormley S, Ilenchuk TT, Iqbal U, Lutes T, Martina M and Mealing $G$ et al.. (2013) In vivo detection of human TRPV6-rich tumors with anti-cancer peptides derived from soricidin. PLOS ONE 8: e58866 [PMID:23554944]

94. Brann JH, Dennis JC, Morrison EE and Fadool DA. (2002) Type-specific inositol 1,4,5-trisphosphate receptor localization in the vomeronasal organ and its interaction with a transient receptor potential channel, TRPC2. J. Neurochem. 83: 1452-60 [PMID:12472899]

95. Brauchi S, Orio P and Latorre R. (2004) Clues to understanding cold sensation: thermodynamics and electrophysiological analysis of the cold receptor TRPM8. Proc. Natl. Acad. Sci. U.S.A. 101: 15494-9 [PMID:15492228]

96. Brierley SM, Castro J, Harrington AM, Hughes PA, Page AJ, Rychkov GY and Blackshaw LA. (2011) TRPA1 contributes to specific mechanically activated currents and sensory neuron mechanical hypersensitivity. J. Physiol. (Lond.) 589: 3575-93 [PMID:21558163]

97. Brierley SM, Hughes PA, Page AJ, Kwan KY, Martin CM, O'Donnell TA, Cooper NJ, Harrington AM, Adam $B$ and Liebregts T et al.. (2009) The ion channel TRPA1 is required for normal mechanosensation and is modulated by algesic stimuli. Gastroenterology 137: 2084-2095.e3 [PMID:19632231]

98. Brixel LR, Monteilh-Zoller MK, Ingenbrandt CS, Fleig A, Penner R, Enklaar T, Zabel BU and Prawitt D. (2010) TRPM5 regulates glucose-stimulated insulin secretion. Pflugers Arch. 460: 69-76 [PMID:20393858]

99. Broad LM, Mogg AJ, Eberle E, Tolley M, Li DL and Knopp KL. (2016) TRPV3 in Drug Development. Pharmaceuticals (Basel) 9: [PMID:27618069]

100. Brône B, Peeters PJ, Marrannes R, Mercken M, Nuydens R, Meert T and Gijsen HJ. (2008) Tear gasses CN, CR, and CS are potent activators of the human TRPA1 receptor. Toxicol. Appl. Pharmacol. 231: 150-6 [PMID:18501939]

101. Bíró T and Kovács L. (2009) An "ice-cold" TR(i)P to skin biology: the role of TRPA1 in human epidermal keratinocytes. J. Invest. Dermatol. 129: 2096-9 [PMID:19809424]

102. Cabanas H, Muraki K, Eaton N, Balinas C, Staines D and Marshall-Gradisnik S. (2018) Loss of Transient Receptor Potential Melastatin 3 ion channel function in natural killer cells from Chronic Fatigue Syndrome/Myalgic Encephalomyelitis patients. Mol. Med. 24: 44 [PMID:30134818]

103. Caceres Al, Brackmann M, Elia MD, Bessac BF, del Camino D, D'Amours M, Witek JS, Fanger CM, Chong JA and Hayward NJ et al.. (2009) A sensory neuronal ion channel essential for airway inflammation and hyperreactivity in asthma. Proc. Natl. Acad. Sci. U.S.A. 106: 9099-104 [PMID:19458046] 
104. Camacho N, Krakow D, Johnykutty S, Katzman PJ, Pepkowitz S, Vriens J, Nilius B, Boyce BF and Cohn DH. (2010) Dominant TRPV4 mutations in nonlethal and lethal metatropic dysplasia. Am. J. Med. Genet. A 152A: 1169-77 [PMID:20425821]

105. Cao DS, Zhong L, Hsieh TH, Abooj M, Bishnoi M, Hughes L and Premkumar LS. (2012) Expression of transient receptor potential ankyrin 1 (TRPA1) and its role in insulin release from rat pancreatic beta cells. PLOS ONE 7: e38005 [PMID:22701540]

106. Cao E, Liao M, Cheng $Y$ and Julius D. (2013) TRPV1 structures in distinct conformations reveal activation mechanisms. Nature 504: 113-8 [PMID:24305161]

107. Cao Y, Posokhova E and Martemyanov KA. (2011) TRPM1 forms complexes with nyctalopin in vivo and accumulates in postsynaptic compartment of ON-bipolar neurons in mGluR6-dependent manner. J.

Neurosci. 31: 11521-6 [PMID:21832182]

108. Carrasquillo R, Tian D, Krishna S, Pollak MR, Greka A and Schlöndorff J. (2012) SNF8, a member of the ESCRT-II complex, interacts with TRPC6 and enhances its channel activity. BMC Cell Biol. 13: 33 [PMID:23171048]

109. Carstens E, Akiyama T, Wilson SR and Bautista DM. (2014) Role of Transient Receptor Potential Channels in Acute and Chronic Itch Itch: Mechanisms and Treatment [PMID:24830011]

110. Castiglioni AJ, Remis NN, Flores EN and García-Añoveros J. (2011) Expression and vesicular localization of mouse Trpml3 in stria vascularis, hair cells, and vomeronasal and olfactory receptor neurons. J. Comp. Neurol. 519: 1095-114 [PMID:21344404]

111. Castillo B, Pörzgen P, Penner R, Horgen FD and Fleig A. (2010) Development and optimization of a highthroughput bioassay for TRPM7 ion channel inhibitors. J Biomol Screen 15: 498-507 [PMID:20413646]

112. Caterina MJ, Leffler A, Malmberg AB, Martin WJ, Trafton J, Petersen-Zeitz KR, Koltzenburg M, Basbaum Al and Julius D. (2000) Impaired nociception and pain sensation in mice lacking the capsaicin receptor. Science 288: 306-13 [PMID:10764638]

113. Caterina MJ, Rosen TA, Tominaga M, Brake AJ and Julius D. (1999) A capsaicin-receptor homologue with a high threshold for noxious heat. Nature 398: 436-41 [PMID:10201375]

114. Caterina MJ, Schumacher MA, Tominaga M, Rosen TA, Levine JD and Julius D. (1997) The capsaicin receptor: a heat-activated ion channel in the pain pathway. Nature 389: 816-24 [PMID:9349813]

115. Cattaruzza F, Spreadbury I, Miranda-Morales M, Grady EF, Vanner S and Bunnett NW. (2010) Transient receptor potential ankyrin-1 has a major role in mediating visceral pain in mice. Am. J. Physiol. Gastrointest. Liver Physiol. 298: G81-91 [PMID:19875705]

116. Cavanaugh DJ, Chesler AT, Bráz JM, Shah NM, Julius D and Basbaum AI. (2011) Restriction of transient receptor potential vanilloid-1 to the peptidergic subset of primary afferent neurons follows its developmental downregulation in nonpeptidergic neurons. J. Neurosci. 31: 10119-27 [PMID:21752988]

117. Cavanaugh DJ, Chesler AT, Jackson AC, Sigal YM, Yamanaka H, Grant R, O'Donnell D, Nicoll RA, Shah NM and Julius D et al.. (2011) Trpv1 reporter mice reveal highly restricted brain distribution and functional expression in arteriolar smooth muscle cells. J. Neurosci. 31: 5067-77 [PMID:21451044]

118. Ceppa E, Cattaruzza F, Lyo V, Amadesi S, Pelayo JC, Poole DP, Vaksman N, Liedtke W, Cohen DM and Grady EF et al.. (2010) Transient receptor potential ion channels V4 and A1 contribute to pancreatitis pain in mice. Am. J. Physiol. Gastrointest. Liver Physiol. 299: G556-71 [PMID:20539005]

119. Chabardès-Garonne D, Mejéan A, Aude JC, Cheval L, Di Stefano A, Gaillard MC, Imbert-Teboul M, Wittner M, Balian C and Anthouard V et al.. (2003) A panoramic view of gene expression in the human kidney. Proc. Natl. Acad. Sci. U.S.A. 100: 13710-5 [PMID:14595018]

120. Chakraborty S, Berwick ZC, Bartlett PJ, Kumar S, Thomas AP, Sturek M, Tune JD and Obukhov AG. (2011) Bromoenol lactone inhibits voltage-gated Ca2+ and transient receptor potential canonical channels. J. Pharmacol. Exp. Ther. 339: 329-40 [PMID:21795434]

121. Chandra M, Zhou H, Li Q, Muallem S, Hofmann SL and Soyombo AA. (2011) A role for the Ca2+ channel TRPML1 in gastric acid secretion, based on analysis of knockout mice. Gastroenterology 140: 857-67 [PMID:21111738]

122. Chang Q, Hoefs S, van der Kemp AW, Topala CN, Bindels RJ and Hoenderop JG. (2005) The beta- 
glucuronidase klotho hydrolyzes and activates the TRPV5 channel. Science 310: 490-3 [PMID:16239475]

123. Chaudhari SS, Kadam AB, Khairatkar-Joshi N, Mukhopadhyay I, Karnik PV, Raghuram A, Rao SS,

Vaiyapuri TS, Wale DP and Bhosale VM et al.. (2013) Synthesis and pharmacological evaluation of novel $\mathrm{N}$-aryl-3,4-dihydro-1'H-spiro[chromene-2,4'-piperidine]-1'-carboxamides as TRPM8 antagonists. Bioorg.

Med. Chem. 21: 6542-53 [PMID:24055075]

124. Chen CC, Keller M, Hess M, Schiffmann R, Urban N, Wolfgardt A, Schaefer M, Bracher F, Biel M and Wahl-Schott $C$ et al.. (2014) A small molecule restores function to TRPML1 mutant isoforms responsible for mucolipidosis type IV. Nat Commun 5: 4681 [PMID:25119295]

125. Chen CS, Bach G and Pagano RE. (1998) Abnormal transport along the lysosomal pathway in mucolipidosis, type IV disease. Proc. Natl. Acad. Sci. U.S.A. 95: 6373-8 [PMID:9600972]

126. Chen J, Joshi SK, DiDomenico S, Perner RJ, Mikusa JP, Gauvin DM, Segreti JA, Han P, Zhang XF and Niforatos W et al.. (2011) Selective blockade of TRPA1 channel attenuates pathological pain without altering noxious cold sensation or body temperature regulation. Pain 152: 1165-72 [PMID:21402443]

127. Chen M, Dong Y and Simard JM. (2003) Functional coupling between sulfonylurea receptor type 1 and a nonselective cation channel in reactive astrocytes from adult rat brain. J. Neurosci. 23: 8568-77 [PMID:13679426]

128. Chen Q, She J, Zeng W, Guo J, Xu H, Bai XC and Jiang Y. (2017) Structure of mammalian endolysosomal TRPML1 channel in nanodiscs. Nature 550: 415-418 [PMID:29019981]

129. Chen X, Numata T, Li M, Mori Y, Orser BA, Jackson MF, Xiong ZG and MacDonald JF. (2010) The modulation of TRPM7 currents by nafamostat mesilate depends directly upon extracellular concentrations of divalent cations. Mol Brain 3: 38 [PMID:21122141]

130. Chen XZ, Vassilev PM, Basora N, Peng JB, Nomura H, Segal Y, Brown EM, Reeders ST, Hediger MA and Zhou J. (1999) Polycystin-L is a calcium-regulated cation channel permeable to calcium ions. Nature 401 : 383-6 [PMID:10517637]

131. Cheng H, Beck A, Launay P, Gross SA, Stokes AJ, Kinet JP, Fleig A and Penner R. (2007) TRPM4 controls insulin secretion in pancreatic beta-cells. Cell Calcium 41: 51-61 [PMID:16806463]

132. Cheng KT, Ong HL, Liu X and Ambudkar IS. (2011) Contribution of TRPC1 and Orai1 to $\mathrm{Ca}(2+)$ entry activated by store depletion. Adv. Exp. Med. Biol. 704: 435-49 [PMID:21290310]

133. Cheng KT, Ong HL, Liu X and Ambudkar IS. (2013) Contribution and regulation of TRPC channels in store-operated Ca2+ entry. Curr Top Membr 71: 149-79 [PMID:23890115]

134. Cheng X, Jin J, Hu L, Shen D, Dong XP, Samie MA, Knoff J, Eisinger B, Liu ML and Huang SIt al.. (2010) TRP channel regulates EGFR signaling in hair morphogenesis and skin barrier formation. Cell 141: 331-43 [PMID:20403327]

135. Cheng X, Shen D, Samie M and Xu H. (2010) Mucolipins: Intracellular TRPML1-3 channelsFEBS Lett. 584: 2013-21 [PMID:20074572]

136. Chu X, Tong Q, Cheung JY, Wozney J, Conrad K, Mazack V, Zhang W, Stahl R, Barber DL and Miller BA. (2004) Interaction of TRPC2 and TRPC6 in erythropoietin modulation of calcium influx. J. Biol. Chem. 279: 10514-22 [PMID:14699131]

137. Chubanov V, Gudermann T and Schlingmann KP. (2005) Essential role for TRPM6 in epithelial magnesium transport and body magnesium homeostasis. Pflugers Arch. 451: 228-34 [PMID:16075242]

138. Chubanov V, Mederos y Schnitzler M, Meißner M, Schäfer S, Abstiens K, Hofmann T and Gudermann T. (2012) Natural and synthetic modulators of SK (K(ca)2) potassium channels inhibit magnesium-dependent activity of the kinase-coupled cation channel TRPM7. Br. J. Pharmacol. 166: 1357-76 [PMID:22242975]

139. Chubanov V, Waldegger S, Mederos y Schnitzler M, Vitzthum H, Sassen MC, Seyberth HW, Konrad M and Gudermann T. (2004) Disruption of TRPM6/TRPM7 complex formation by a mutation in the TRPM6 gene causes hypomagnesemia with secondary hypocalcemia. Proc. Natl. Acad. Sci. U.S.A. 101: 2894-9 [PMID:14976260]

140. Chung KK, Freestone PS and Lipski J. (2011) Expression and functional properties of TRPM2 channels in dopaminergic neurons of the substantia nigra of the rat. J. Neurophysiol. 106: 2865-75 [PMID:21900507]

141. Chung MK, Güler AD and Caterina MJ. (2005) Biphasic currents evoked by chemical or thermal activation 
of the heat-gated ion channel, TRPV3. J. Biol. Chem. 280: 15928-41 [PMID:15722340]

142. Chung MK, Lee $\mathrm{H}$ and Caterina MJ. (2003) Warm temperatures activate TRPV4 in mouse 308 keratinocytes. J. Biol. Chem. 278: 32037-46 [PMID:12783886]

143. Chung MK, Lee H, Mizuno A, Suzuki M and Caterina MJ. (2004) 2-aminoethoxydiphenyl borate activates and sensitizes the heat-gated ion channel TRPV3. J. Neurosci. 24: 5177-82 [PMID:15175387]

144. Chung YH, Sun Ahn H, Kim D, Hoon Shin D, Su Kim S, Yong Kim K, Bok Lee W and Ik Cha C. (2006) Immunohistochemical study on the distribution of TRPC channels in the rat hippocampus. Brain Res. 1085: 132-7 [PMID:16580647]

145. Clapham DE, Montell C, Schultz G, Julius D and International Union of Pharmacology. (2003) International Union of Pharmacology. XLIII. Compendium of voltage-gated ion channels: transient receptor potential channels. Pharmacol. Rev. 55: 591-6 [PMID:14657417]

146. Clark K, Langeslag M, van Leeuwen B, Ran L, Ryazanov AG, Figdor CG, Moolenaar WH, Jalink K and van Leeuwen FN. (2006) TRPM7, a novel regulator of actomyosin contractility and cell adhesion. EMBO J. 25: 290-301 [PMID:16407977]

147. Colburn RW, Lubin ML, Stone DJ, Wang Y, Lawrence D, D'Andrea MR, Brandt MR, Liu Y, Flores CM and Qin N. (2007) Attenuated cold sensitivity in TRPM8 null mice. Neuron 54: 379-86 [PMID:17481392]

148. Colletti GA, Miedel MT, Quinn J, Andharia N, Weisz OA and Kiselyov K. (2012) Loss of lysosomal ion channel transient receptor potential channel mucolipin-1 (TRPML1) leads to cathepsin B-dependent apoptosis. J. Biol. Chem. 287: 8082-91 [PMID:22262857]

149. Colsoul B, Schraenen A, Lemaire K, Quintens R, Van Lommel L, Segal A, Owsianik G, Talavera K, Voets T and Margolskee RF et al.. (2010) Loss of high-frequency glucose-induced Ca2+ oscillations in pancreatic islets correlates with impaired glucose tolerance in Trpm5-/- mice. Proc. Natl. Acad. Sci. U.S.A. 107: 520813 [PMID:20194741]

150. Compan V, Baroja-Mazo A, López-Castejón G, Gomez Al, Martínez CM, Angosto D, Montero MT, Herranz AS, Bazán E and Reimers D et al.. (2012) Cell volume regulation modulates NLRP3 inflammasome activation. Immunity 37: 487-500 [PMID:22981536]

151. Cordeiro S, Seyler S, Stindl J, Milenkovic VM and Strauss O. (2010) Heat-sensitive TRPV channels in retinal pigment epithelial cells: regulation of VEGF-A secretion. Invest. Ophthalmol. Vis. Sci. 51: 6001-8 [PMID:20539001]

152. Corey DP, García-Añoveros J, Holt JR, Kwan KY, Lin SY, Vollrath MA, Amalfitano A, Cheung EL, Derfler $\mathrm{BH}$ and Duggan A et al.. (2004) TRPA1 is a candidate for the mechanosensitive transduction channel of vertebrate hair cells. Nature 432: 723-30 [PMID:15483558]

153. Correll CC, Phelps PT, Anthes JC, Umland S and Greenfeder S. (2004) Cloning and pharmacological characterization of mouse TRPV1. Neurosci. Lett. 370: 55-60 [PMID:15489017]

154. Cuajungco MP, Grimm C, Oshima K, D'hoedt D, Nilius B, Mensenkamp AR, Bindels RJ, Plomann M and Heller S. (2006) PACSINs bind to the TRPV4 cation channel. PACSIN 3 modulates the subcellular localization of TRPV4. J. Biol. Chem. 281: 18753-62 [PMID:16627472]

155. Cuajungco MP and Samie MA. (2008) The varitint-waddler mouse phenotypes and the TRPML3 ion channel mutation: cause and consequence. Pflugers Arch. 457: 463-73 [PMID:18504603]

156. Cuajungco MP, Silva J, Habibi A and Valadez JA. (2016) The mucolipin-2 (TRPML2) ion channel: a tissuespecific protein crucial to normal cell function. Pflugers Arch. 468: 177-92 [PMID:26336837]

157. Curcio-Morelli C, Charles FA, Micsenyi MC, Cao Y, Venugopal B, Browning MF, Dobrenis K, Cotman SL, Walkley SU and Slaugenhaupt SA. (2010) Macroautophagy is defective in mucolipin-1-deficient mouse neurons. Neurobiol. Dis. 40: 370-7 [PMID:20600908]

158. Curcio-Morelli C, Zhang P, Venugopal B, Charles FA, Browning MF, Cantiello HF and Slaugenhaupt SA. (2010) Functional multimerization of mucolipin channel proteins. J. Cell. Physiol. 222: 328-35 [PMID:19885840]

159. da Costa DS, Meotti FC, Andrade EL, Leal PC, Motta EM and Calixto JB. (2010) The involvement of the transient receptor potential A1 (TRPA1) in the maintenance of mechanical and cold hyperalgesia in persistent inflammation. Pain 148: 431-7 [PMID:20056530] 
160. Dai XQ, Ramji A, Liu Y, Li Q, Karpinski E and Chen XZ. (2007) Inhibition of TRPP3 channel by amiloride and analogs. Mol. Pharmacol. 72: 1576-85 [PMID:17804601]

161. Damak S, Rong M, Yasumatsu K, Kokrashvili Z, Pérez CA, Shigemura N, Yoshida R, Mosinger Jr B, Glendinning JI and Ninomiya $Y$ et al.. (2006) Trpm5 null mice respond to bitter, sweet, and umami compounds. Chem. Senses 31: 253-64 [PMID:16436689]

162. Danso-Abeam D, Zhang J, Dooley J, Staats KA, Van Eyck L, Van Brussel T, Zaman S, Hauben E, Van de Velde M and Morren MA et al.. (2013) Olmsted syndrome: exploration of the immunological phenotype. Orphanet J Rare Dis 8: 79 [PMID:23692804]

163. Dattilo M, Penington NJ and Williams K. (2008) Inhibition of TRPC5 channels by intracellular ATPMol. Pharmacol. 73: 42-9 [PMID:17925457]

164. Davare MA, Fortin DA, Saneyoshi T, Nygaard S, Kaech S, Banker G, Soderling TR and Wayman GA. (2009) Transient receptor potential canonical 5 channels activate $\mathrm{Ca2}+$ /calmodulin kinase Igamma to promote axon formation in hippocampal neurons. J. Neurosci. 29: 9794-808 [PMID:19657032]

165. Davis J, Burr AR, Davis GF, Birnbaumer L and Molkentin JD. (2012) A TRPC6-dependent pathway for myofibroblast transdifferentiation and wound healing in vivo. Dev. Cell 23: 705-15 [PMID:23022034]

166. Davis JB, Gray J, Gunthorpe MJ, Hatcher JP, Davey PT, Overend P, Harries MH, Latcham J, Clapham C and Atkinson $\mathrm{K}$ et al.. (2000) Vanilloid receptor-1 is essential for inflammatory thermal hyperalgesia. Nature 405: 183-7 [PMID:10821274]

167. Davis MI, Hunt JP, Herrgard S, Ciceri P, Wodicka LM, Pallares G, Hocker M, Treiber DK and Zarrinkar PP. (2011) Comprehensive analysis of kinase inhibitor selectivity. Nat. Biotechnol. 29: 1046-51 [PMID:22037378]

168. de Groot T, Bindels RJ and Hoenderop JG. (2008) TRPV5: an ingeniously controlled calcium channel. Kidney Int. 74: 1241-6 [PMID:18596722]

169. de Groot T, Lee K, Langeslag M, Xi Q, Jalink K, Bindels RJ and Hoenderop JG. (2009) Parathyroid hormone activates TRPV5 via PKA-dependent phosphorylation. J. Am. Soc. Nephrol. 20: 1693-704 [PMID:19423690]

170. De March Z, Giampà C, Patassini S, Bernardi G and Fusco FR. (2006) Cellular localization of TRPC5 in the substantia nigra of rat. Neurosci. Lett. 402: 35-9 [PMID:16635549]

171. De Petrocellis L, Orlando P, Moriello AS, Aviello G, Stott C, Izzo AA and Di Marzo V. (2012) Cannabinoid actions at TRPV channels: effects on TRPV3 and TRPV4 and their potential relevance to gastrointestinal inflammation. Acta Physiol (Oxf) 204: 255-66 [PMID:21726418]

172. DeCaen PG, Delling M, Vien TN and Clapham DE. (2013) Direct recording and molecular identification of the calcium channel of primary cilia. Nature 504: 315-8 [PMID:24336289]

173. Deeds J, Cronin F and Duncan LM. (2000) Patterns of melastatin mRNA expression in melanocytic tumors. Hum. Pathol. 31: 1346-56 [PMID:11112208]

174. DeHaven WI, Jones BF, Petranka JG, Smyth JT, Tomita T, Bird GS and Putney Jr JW. (2009) TRPC channels function independently of STIM1 and Orai1. J. Physiol. (Lond.) 587: 2275-98 [PMID:19332491]

175. del Camino D, Murphy S, Heiry M, Barrett LB, Earley TJ, Cook CA, Petrus MJ, Zhao M, D'Amours M and Deering $\mathrm{N}$ et al.. (2010) TRPA1 contributes to cold hypersensitivity.J. Neurosci. 30: 15165-74 [PMID:21068322]

176. Delany NS, Hurle M, Facer P, Alnadaf T, Plumpton C, Kinghorn I, See CG, Costigan M, Anand P and Woolf CJ et al.. (2001) Identification and characterization of a novel human vanilloid receptor-like protein, VRL-2. Physiol. Genomics 4: 165-74 [PMID:11160995]

177. Delmas P. (2005) Polycystins: polymodal receptor/ion-channel cellular sensors.Pflugers Arch. 451: 264-76 [PMID:15889307]

178. Delmas P, Nauli SM, Li X, Coste B, Osorio N, Crest M, Brown DA and Zhou J. (2004) Gating of the polycystin ion channel signaling complex in neurons and kidney cells. FASEB J. 18: 740-2 [PMID:14766803]

179. Delmas P, Padilla F, Osorio N, Coste B, Raoux M and Crest M. (2004) Polycystins, calcium signaling, and human diseases. Biochem. Biophys. Res. Commun. 322: 1374-83 [PMID:15336986] 
180. Deng HX, Klein CJ, Yan J, Shi Y, Wu Y, Fecto F, Yau HJ, Yang Y, Zhai H and Siddique Net al.. (2010) Scapuloperoneal spinal muscular atrophy and CMT2C are allelic disorders caused by alterations in TRPV4. Nat. Genet. 42: 165-9 [PMID:20037587]

181. Deng Z, Paknejad N, Maksaev G, Sala-Rabanal M, Nichols CG, Hite RK and Yuan P. (2018) Cryo-EM and $\mathrm{X}$-ray structures of TRPV4 reveal insight into ion permeation and gating mechanisms. Nat. Struct. Mol. Biol. 25: 252-260 [PMID:29483651]

182. Deol MS. (1954) The anomalies of the labyrinth of the mutants varitint-waddler, shaker-2 and jerker in the mouse. Journal of Genetics 52: 558

183. Desai BN, Krapivinsky G, Navarro B, Krapivinsky L, Carter BC, Febvay S, Delling M, Penumaka A, Ramsey IS and Manasian Y et al.. (2012) Cleavage of TRPM7 releases the kinase domain from the ion channel and regulates its participation in Fas-induced apoptosis. Dev. Cell 22: 1149-62 [PMID:22698280]

184. Devi S, Markandeya Y, Maddodi N, Dhingra A, Vardi N, Balijepalli RC and Setaluri V. (2013) Metabotropic glutamate receptor 6 signaling enhances TRPM1 calcium channel function and increases melanin content in human melanocytes. Pigment Cell Melanoma Res 26: 348-56 [PMID:23452348]

185. Dhaka A, Earley TJ, Watson J and Patapoutian A. (2008) Visualizing cold spots: TRPM8-expressing sensory neurons and their projections. J. Neurosci. 28: 566-75 [PMID:18199758]

186. Dhaka A, Murray AN, Mathur J, Earley TJ, Petrus MJ and Patapoutian A. (2007) TRPM8 is required for cold sensation in mice. Neuron 54: 371-8 [PMID:17481391]

187. Dhaka A, Viswanath $V$ and Patapoutian A. (2006) Trp ion channels and temperature sensation Annu. Rev. Neurosci. 29: 135-61 [PMID:16776582]

188. Dhingra A, Fina ME, Neinstein A, Ramsey DJ, Xu Y, Fishman GA, Alexander KR, Qian H, Peachey NS and Gregg RG et al.. (2011) Autoantibodies in melanoma-associated retinopathy target TRPM1 cation channels of retinal ON bipolar cells. J. Neurosci. 31: 3962-7 [PMID:21411639]

189. Di A, Gao XP, Qian F, Kawamura T, Han J, Hecquet C, Ye RD, Vogel SM and Malik AB. (2012) The redox-sensitive cation channel TRPM2 modulates phagocyte ROS production and inflammation. Nat. Immunol. 13: 29-34 [PMID:22101731]

190. Di Palma F, Belyantseva IA, Kim HJ, Vogt TF, Kachar B and Noben-Trauth K. (2002) Mutations in Mcoln3 associated with deafness and pigmentation defects in varitint-waddler (Va) mice. Proc. Natl. Acad. Sci. U.S.A. 99: 14994-9 [PMID:12403827]

191. Dietrich A, Fahlbusch M and Gudermann T. (2014) Classical Transient Receptor Potential 1 (TRPC1): Channel or Channel Regulator? Cells 3: 939-62 [PMID:25268281]

192. Dietrich A, Kalwa H, Rost BR and Gudermann T. (2005) The diacylgylcerol-sensitive TRPC3/6/7 subfamily of cation channels: functional characterization and physiological relevance. Pflugers Arch. 451: 72-80 [PMID:15971081]

193. Dietrich A, Mederos Y Schnitzler M, Gollasch M, Gross V, Storch U, Dubrovska G, Obst M, Yildirim E, Salanova B and Kalwa $\mathrm{H}$ et al.. (2005) Increased vascular smooth muscle contractility in TRPC6-/- mice. Mol. Cell. Biol. 25: 6980-9 [PMID:16055711]

194. Doerner JF, Hatt $\mathrm{H}$ and Ramsey IS. (2011) Voltage- and temperature-dependent activation of TRPV3 channels is potentiated by receptor-mediated PI(4,5)P2 hydrolysis. J. Gen. Physiol. 137: 271-88 [PMID:21321070]

195. Dong XP, Cheng X, Mills E, Delling M, Wang F, Kurz T and Xu H. (2008) The type IV mucolipidosisassociated protein TRPML1 is an endolysosomal iron release channel. Nature 455: 992-6 [PMID:18794901]

196. Dong XP, Shen D, Wang X, Dawson T, Li X, Zhang Q, Cheng X, Zhang Y, Weisman LS and Delling Met al.. (2010) $\mathrm{PI}(3,5) \mathrm{P}(2)$ controls membrane trafficking by direct activation of mucolipin $\mathrm{Ca}(2+)$ release channels in the endolysosome. Nat Commun 1: 38 [PMID:20802798]

197. Dong XP, Wang X, Shen D, Chen S, Liu M, Wang Y, Mills E, Cheng X, Delling M and Xu H. (2009) Activating mutations of the TRPML1 channel revealed by proline-scanning mutagenesis. J. Biol. Chem. 284: 32040-52 [PMID:19638346]

198. Dorovkov MV and Ryazanov AG. (2004) Phosphorylation of annexin I by TRPM7 channel-kinase.J. Biol. 
Chem. 279: 50643-6 [PMID:15485879]

199. Du J, Xie $\mathrm{J}$ and Yue L. (2009) Modulation of TRPM2 by acidic $\mathrm{pH}$ and the underlying mechanisms for $\mathrm{pH}$ sensitivity. J. Gen. Physiol. 134: 471-88 [PMID:19917732]

200. Du J, Xie J and Yue L. (2009) Intracellular calcium activates TRPM2 and its alternative spliced isoforms. Proc. Natl. Acad. Sci. U.S.A. 106: 7239-44 [PMID:19372375]

201. Du J, Xie J, Zhang Z, Tsujikawa H, Fusco D, Silverman D, Liang B and Yue L. (2010) TRPM7-mediated Ca2+ signals confer fibrogenesis in human atrial fibrillation. Circ. Res. 106: 992-1003 [PMID:20075334]

202. Du S, Araki I, Yoshiyama M, Nomura T and Takeda M. (2007) Transient receptor potential channel A1 involved in sensory transduction of rat urinary bladder through C-fiber pathway. Urology 70: 826-31 [PMID:17991581]

203. Duncan LM, Deeds J, Cronin FE, Donovan M, Sober AJ, Kauffman M and McCarthy JJ. (2001) Melastatin expression and prognosis in cutaneous malignant melanoma. J. Clin. Oncol. 19: 568-76 [PMID:11208852]

204. Duncan LM, Deeds J, Hunter J, Shao J, Holmgren LM, Woolf EA, Tepper RI and Shyjan AW. (1998) Down-regulation of the novel gene melastatin correlates with potential for melanoma metastasis. Cancer Res. 58: 1515-20 [PMID:9537257]

205. Dunn KM, Hill-Eubanks DC, Liedtke WB and Nelson MT. (2013) TRPV4 channels stimulate Ca2+-induced $\mathrm{Ca} 2+$ release in astrocytic endfeet and amplify neurovascular coupling responses. Proc. Natl. Acad. Sci. U.S.A. 110: 6157-62 [PMID:23530219]

206. Dutta Banik D, Martin LE, Freichel M, Torregrossa AM and Medler KF. (2018) TRPM4 and TRPM5 are both required for normal signaling in taste receptor cells. Proc. Natl. Acad. Sci. U.S.A. 115: E772-E781 [PMID:29311301]

207. Earley S, Gonzales AL and Crnich R. (2009) Endothelium-dependent cerebral artery dilation mediated by TRPA1 and Ca2+-Activated K+ channels. Circ. Res. 104: 987-94 [PMID:19299646]

208. Earley S, Pauyo T, Drapp R, Tavares MJ, Liedtke W and Brayden JE. (2009) TRPV4-dependent dilation of peripheral resistance arteries influences arterial pressure. Am. J. Physiol. Heart Circ. Physiol.297: H1096102 [PMID:19617407]

209. Earley S, Waldron BJ and Brayden JE. (2004) Critical role for transient receptor potential channel TRPM4 in myogenic constriction of cerebral arteries. Circ. Res. 95: 922-9 [PMID:15472118]

210. Eberhardt MJ, Filipovic MR, Leffler A, de la Roche J, Kistner K, Fischer MJ, Fleming T, Zimmermann K, Ivanovic-Burmazovic I and Nawroth PP et al.. (2012) Methylglyoxal activates nociceptors through transient receptor potential channel A1 (TRPA1): a possible mechanism of metabolic neuropathies. J. Biol. Chem.

287: 28291-306 [PMID:22740698]

211. Eichelsdoerfer JL, Evans JA, Slaugenhaupt SA and Cuajungco MP. (2010) Zinc dyshomeostasis is linked with the loss of mucolipidosis IV-associated TRPML1 ion channel. J. Biol. Chem. 285: 34304-8 [PMID:20864526]

212. Eid SR, Crown ED, Moore EL, Liang HA, Choong KC, Dima S, Henze DA, Kane SA and Urban MO. (2008) HC-030031, a TRPA1 selective antagonist, attenuates inflammatory- and neuropathy-induced mechanical hypersensitivity. Mol Pain 4: 48 [PMID:18954467]

213. El Karim IA, Linden GJ, Curtis TM, About I, McGahon MK, Irwin CR, Killough SA and Lundy FT. (2011) Human dental pulp fibroblasts express the "cold-sensing" transient receptor potential channels TRPA1 and TRPM8. J Endod 37: 473-8 [PMID:21419293]

214. El Karim IA, Linden GJ, Curtis TM, About I, McGahon MK, Irwin CR and Lundy FT. (2011) Human odontoblasts express functional thermo-sensitive TRP channels: implications for dentin sensitivity. Pain 152: 2211-23 [PMID:21168271]

215. El Kouhen R, Surowy CS, Bianchi BR, Neelands TR, McDonald HA, Niforatos W, Gomtsyan A, Lee CH, Honore P and Sullivan JP et al.. (2005) A-425619 [1-isoquinolin-5-yl-3-(4-trifluoromethyl-benzyl)-urea], a novel and selective transient receptor potential type $\mathrm{V} 1$ receptor antagonist, blocks channel activation by vanilloids, heat, and acid. J. Pharmacol. Exp. Ther. 314: 400-9 [PMID:15837819]

216. Emir TLR. (2017) various In Neurobiology of TRP Channels (2nd Ed.) Edited by Emir TLR: CRC Press/Taylor \& Francis: [PMID:29356469] 
217. Engel MA, Leffler A, Niedermirtl F, Babes A, Zimmermann K, Filipović MR, Izydorczyk I, Eberhardt M, Kichko TI and Mueller-Tribbensee SM et al.. (2011) TRPA1 and substance P mediate colitis in mice. Gastroenterology 141: 1346-58 [PMID:21763243]

218. Enklaar T, Esswein M, Oswald M, Hilbert K, Winterpacht A, Higgins M, Zabel B and Prawitt D. (2000) Mtr1, a novel biallelically expressed gene in the center of the mouse distal chromosome 7 imprinting cluster, is a member of the Trp gene family. Genomics 67: 179-87 [PMID:10903843]

219. Erickson LA, Letts GA, Shah SM, Shackelton JB and Duncan LM. (2009) TRPM1 (Melastatin-1/MLSN1) mRNA expression in Spitz nevi and nodular melanomas. Mod. Pathol. 22: 969-76 [PMID:19396153]

220. Escalera J, von Hehn CA, Bessac BF, Sivula M and Jordt SE. (2008) TRPA1 mediates the noxious effects of natural sesquiterpene deterrents. J. Biol. Chem. 283: 24136-44 [PMID:18550530]

221. Everaerts W, Vriens J, Owsianik G, Appendino G, Voets T, De Ridder D and Nilius B. (2010) Functional characterization of transient receptor potential channels in mouse urothelial cells. Am. J. Physiol. Renal Physiol. 298: F692-701 [PMID:20015940]

222. Everaerts W, Zhen X, Ghosh D, Vriens J, Gevaert T, Gilbert JP, Hayward NJ, McNamara CR, Xue F and Moran MM et al.. (2010) Inhibition of the cation channel TRPV4 improves bladder function in mice and rats with cyclophosphamide-induced cystitis. Proc. Natl. Acad. Sci. U.S.A. 107: 19084-9 [PMID:20956320]

223. Facemire CS, Mohler PJ and Arendshorst WJ. (2004) Expression and relative abundance of short transient receptor potential channels in the rat renal microcirculation. Am. J. Physiol. Renal Physiol. 286: F546-51 [PMID:14678949]

224. Fajardo O, Meseguer V, Belmonte $C$ and Viana F. (2008) TRPA1 channels mediate cold temperature sensing in mammalian vagal sensory neurons: pharmacological and genetic evidence. J. Neurosci. 28: 7863-75 [PMID:18667618]

225. Falardeau JL, Kennedy JC, Acierno Jr JS, Sun M, Stahl S, Goldin E and Slaugenhaupt SA. (2002) Cloning and characterization of the mouse Mcoln1 gene reveals an alternatively spliced transcript not seen in humans. BMC Genomics 3: 3 [PMID:11897010]

226. Fantozzi I, Zhang S, Platoshyn O, Remillard CV, Cowling RT and Yuan JX. (2003) Hypoxia increases AP1 binding activity by enhancing capacitative $\mathrm{Ca2}+$ entry in human pulmonary artery endothelial cells. Am. J. Physiol. Lung Cell Mol. Physiol. 285: L1233-45 [PMID:12909593]

227. Fecher-Trost $C$, Weissgerber $P$ and Wissenbach U. (2014) TRPV6 channels. Handb Exp Pharmacol 222: 359-84 [PMID:24756713]

228. Fernandes ES, Vong CT, Quek S, Cheong J, Awal S, Gentry C, Aubdool AA, Liang L, Bodkin JV and Bevan S et al.. (2013) Superoxide generation and leukocyte accumulation: key elements in the mediation of leukotriene $\mathrm{B}_{4}$-induced itch by transient receptor potential ankyrin 1 and transient receptor potential vanilloid 1. FASEB J. 27: 1664-73 [PMID:23271050]

229. Fernihough J, Gentry C, Bevan S and Winter J. (2005) Regulation of calcitonin gene-related peptide and TRPV1 in a rat model of osteoarthritis. Neurosci. Lett. 388: 75-80 [PMID:16039054]

230. Fleig A and Penner R. (2004) The TRPM ion channel subfamily: molecular, biophysical and functional features. Trends Pharmacol. Sci. 25: 633-9 [PMID:15530641]

231. Fliegert R, Bauche A, Wolf Pérez AM, Watt JM, Rozewitz MD, Winzer R, Janus M, Gu F, Rosche A and Harneit A et al.. (2017) 2'-Deoxyadenosine 5'-diphosphoribose is an endogenous TRPM2 superagonist. Nat. Chem. Biol. 13: 1036-1044 [PMID:28671679]

232. Fois G, Wittekindt O, Zheng X, Felder ET, Miklavc P, Frick M, Dietl P and Felder E. (2012) An ultra fast detection method reveals strain-induced $\mathrm{Ca}(2+)$ entry via TRPV2 in alveolar type II cells. Biomech Model Mechanobiol 11: 959-71 [PMID:22190268]

233. Fonfria E, Marshall IC, Benham CD, Boyfield I, Brown JD, Hill K, Hughes JP, Skaper SD and McNulty S. (2004) TRPM2 channel opening in response to oxidative stress is dependent on activation of poly(ADPribose) polymerase. Br. J. Pharmacol. 143: 186-92 [PMID:15302683]

234. Fonfria E, Marshall IC, Boyfield I, Skaper SD, Hughes JP, Owen DE, Zhang W, Miller BA, Benham CD and McNulty S. (2005) Amyloid beta-peptide(1-42) and hydrogen peroxide-induced toxicity are mediated by TRPM2 in rat primary striatal cultures. J. Neurochem. 95: 715-23 [PMID:16104849] 
235. Fonfria E, Mattei C, Hill K, Brown JT, Randall A, Benham CD, Skaper SD, Campbell CA, Crook B and Murdock PR et al.. (2006) TRPM2 is elevated in the tMCAO stroke model, transcriptionally regulated, and functionally expressed in C13 microglia. J. Recept. Signal Transduct. Res. 26: 179-98 [PMID:16777714]

236. Fonfria E, Murdock PR, Cusdin FS, Benham CD, Kelsell RE and McNulty S. (2006) Tissue distribution profiles of the human TRPM cation channel family. J. Recept. Signal Transduct. Res. 26: 159-78 [PMID:16777713]

237. Frederick J, Buck ME, Matson DJ and Cortright DN. (2007) Increased TRPA1, TRPM8, and TRPV2 expression in dorsal root ganglia by nerve injury. Biochem. Biophys. Res. Commun. 358: 1058-64 [PMID:17517374]

238. Freichel M, Suh SH, Pfeifer A, Schweig U, Trost C, Weissgerber P, Biel M, Philipp S, Freise D and Droogmans $\mathrm{G}$ et al.. (2001) Lack of an endothelial store-operated $\mathrm{Ca2}+$ current impairs agonist-dependent vasorelaxation in TRP4-/- mice. Nat. Cell Biol. 3: 121-7 [PMID:11175743]

239. Freichel M, Vennekens R, Olausson J, Stolz S, Philipp SE, Weissgerber P and Flockerzi V. (2005) Functional role of TRPC proteins in native systems: implications from knockout and knock-down studies. $J$. Physiol. (Lond.) 567: 59-66 [PMID:15975974]

240. Friedlova E, Grycova L, Holakovska B, Silhan J, Janouskova H, Sulc M, Obsilova V, Obsil T and Teisinger J. (2010) The interactions of the C-terminal region of the TRPC6 channel with calmodulin. Neurochem. Int. 56: 363-6 [PMID:19932145]

241. Fujita F, Moriyama T, Higashi T, Shima A and Tominaga M. (2007) Methyl p-hydroxybenzoate causes pain sensation through activation of TRPA1 channels. Br. J. Pharmacol. 151: 153-60 [PMID:17351650]

242. Fujita F, Uchida K, Moriyama T, Shima A, Shibasaki K, Inada H, Sokabe T and Tominaga M. (2008) Intracellular alkalization causes pain sensation through activation of TRPA1 in mice. J. Clin. Invest. 118: 4049-57 [PMID:19033673]

243. Galizia L, Pizzoni A, Fernandez J, Rivarola V, Capurro C and Ford P. (2012) Functional interaction between AQP2 and TRPV4 in renal cells. J. Cell. Biochem. 113: 580-9 [PMID:21938744]

244. Gallagher AR, Cedzich A, Gretz N, Somlo S and Witzgall R. (2000) The polycystic kidney disease protein PKD2 interacts with Hax-1, a protein associated with the actin cytoskeleton. Proc. Natl. Acad. Sci. U.S.A. 97: 4017-22 [PMID:10760273]

245. Garcia ZI, Bruhl A, Gonzales AL and Earley S. (2011) Basal protein kinase C $\delta$ activity is required for membrane localization and activity of TRPM4 channels in cerebral artery smooth muscle cells. Channels (Austin) 5: 210-4 [PMID:21406958]

246. García-Añoveros J and Nagata K. (2007) TRPA1. Handb Exp Pharmacol 347-62 [PMID:17217068]

247. Gasser A, Glassmeier G, Fliegert R, Langhorst MF, Meinke S, Hein D, Krüger S, Weber K, Heiner I and Oppenheimer $\mathrm{N}$ et al.. (2006) Activation of T cell calcium influx by the second messenger ADP-ribose $J$. Biol. Chem. 281: 2489-96 [PMID:16316998]

248. Gaunt HJ, Vasudev NS and Beech DJ. (2016) Transient receptor potential canonical 4 and 5 proteins as targets in cancer therapeutics. Eur. Biophys. J. 45: 611-620 [PMID:27289383]

249. Gavva NR, Tamir R, Qu Y, Klionsky L, Zhang TJ, Immke D, Wang J, Zhu D, Vanderah TW and Porreca F et al.. (2005) AMG 9810 [(E)-3-(4-t-butylphenyl)-N-(2,3-dihydrobenzo[b][1,4] dioxin-6-yl)acrylamide], a novel vanilloid receptor 1 (TRPV1) antagonist with antihyperalgesic properties. J. Pharmacol. Exp. Ther. 313: 474-84 [PMID:15615864]

250. Geppetti P and Trevisani M. (2004) Activation and sensitisation of the vanilloid receptor: role in gastrointestinal inflammation and function. Br. J. Pharmacol. 141: 1313-20 [PMID:15051629]

251. Gevaert T, Vriens J, Segal A, Everaerts W, Roskams T, Talavera K, Owsianik G, Liedtke W, Daelemans D and Dewachter I et al.. (2007) Deletion of the transient receptor potential cation channel TRPV4 impairs murine bladder voiding. J. Clin. Invest. 117: 3453-62 [PMID:17948126]

252. Giamarchi A, Padilla F, Coste B, Raoux M, Crest M, Honoré E and Delmas P. (2006) The versatile nature of the calcium-permeable cation channel TRPP2. EMBO Rep. 7: 787-93 [PMID:16880824]

253. Gibbs JL, Melnyk JL and Basbaum Al. (2011) Differential TRPV1 and TRPV2 channel expression in dental pulp. J. Dent. Res. 90: 765-70 [PMID:21406609] 
254. Gibbs RA, Weinstock GM, Metzker ML, Muzny DM, Sodergren EJ, Scherer S, Scott G, Steffen D, Worley $\mathrm{KC}$ and Burch PE et al.. (2004) Genome sequence of the Brown Norway rat yields insights into mammalian evolution. Nature 428: 493-521 [PMID:15057822]

255. Gilliam JC and Wensel TG. (2011) TRP channel gene expression in the mouse retina.Vision Res. 51: 2440-52 [PMID:22037305]

256. Gkika D, Hsu YJ, van der Kemp AW, Christakos S, Bindels RJ and Hoenderop JG. (2006) Critical role of the epithelial $\mathrm{Ca} 2+$ channel TRPV5 in active Ca2+ reabsorption as revealed by TRPV5/calbindin-D28K knockout mice. J. Am. Soc. Nephrol.17: 3020-7 [PMID:17005931]

257. Gkika D, Mahieu F, Nilius B, Hoenderop JG and Bindels RJ. (2004) 80K-H as a new Ca2+ sensor regulating the activity of the epithelial $\mathrm{Ca} 2+$ channel transient receptor potential cation channel $\mathrm{V} 5$ (TRPV5). J. Biol. Chem. 279: 26351-7 [PMID:15100231]

258. Gomtsyan A, Schmidt RG, Bayburt EK, Gfesser GA, Voight EA, Daanen JF, Schmidt DL, Cowart MD, Liu $\mathrm{H}$ and Altenbach RJ et al.. (2016) Synthesis and Pharmacology of (Pyridin-2-yl)methanol Derivatives as Novel and Selective Transient Receptor Potential Vanilloid 3 Antagonists. J. Med. Chem. 59: 4926-47 [PMID:27077528]

259. Gonzalez-Perrett S, Batelli M, Kim K, Essafi M, Timpanaro G, Moltabetti N, Reisin IL, Arnaout MA and Cantiello HF. (2002) Voltage dependence and pH regulation of human polycystin-2-mediated cation channel activity. J. Biol. Chem. 277: 24959-66 [PMID:11991947]

260. Gottlieb P, Folgering J, Maroto R, Raso A, Wood TG, Kurosky A, Bowman C, Bichet D, Patel A and Sachs F et al.. (2008) Revisiting TRPC1 and TRPC6 mechanosensitivity.Pflugers Arch. 455: 1097-103 [PMID:17957383]

261. Grace MS, Baxter M, Dubuis E, Birrell MA and Belvisi MG. (2014) Transient receptor potential (TRP) channels in the airway: role in airway disease. Br. J. Pharmacol. 171: 2593-607 [PMID:24286227]

262. Gracheva EO, Ingolia NT, Kelly YM, Cordero-Morales JF, Hollopeter G, Chesler AT, Sánchez EE, Perez JC, Weissman JS and Julius D. (2010) Molecular basis of infrared detection by snakes. Nature 464: 100611 [PMID:20228791]

263. Gradilone SA, Masyuk AI, Splinter PL, Banales JM, Huang BQ, Tietz PS, Masyuk TV and Larusso NF. (2007) Cholangiocyte cilia express TRPV4 and detect changes in luminal tonicity inducing bicarbonate secretion. Proc. Natl. Acad. Sci. U.S.A. 104: 19138-43 [PMID:18024594]

264. Grand T, Demion M, Norez C, Mettey Y, Launay P, Becq F, Bois P and Guinamard R. (2008) 9phenanthrol inhibits human TRPM4 but not TRPM5 cationic channels. Br. J. Pharmacol. 153: 1697-705 [PMID:18297105]

265. Gratzke C, Streng T, Waldkirch E, Sigl K, Stief C, Andersson KE and Hedlund P. (2009) Transient receptor potential A1 (TRPA1) activity in the human urethra--evidence for a functional role for TRPA1 in the outflow region. Eur. Urol. 55: 696-704 [PMID:18468780]

266. Gregus AM, Doolen S, Dumlao DS, Buczynski MW, Takasusuki T, Fitzsimmons BL, Hua XY, Taylor BK, Dennis EA and Yaksh TL. (2012) Spinal 12-lipoxygenase-derived hepoxilin A3 contributes to inflammatory hyperalgesia via activation of TRPV1 and TRPA1 receptors. Proc. Natl. Acad. Sci. U.S.A. 109: 6721-6 [PMID:22493235]

267. Greka A, Navarro B, Oancea E, Duggan A and Clapham DE. (2003) TRPC5 is a regulator of hippocampal neurite length and growth cone morphology. Nat. Neurosci. 6: 837-45 [PMID:12858178]

268. Grimm C. (2016) Endolysosomal Cation Channels as Therapeutic Targets-Pharmacology of TRPML Channels Messenger 5: 30-36

269. Grimm C, Cuajungco MP, van Aken AF, Schnee M, Jörs S, Kros CJ, Ricci AJ and Heller S. (2007) A helixbreaking mutation in TRPML3 leads to constitutive activity underlying deafness in the varitint-waddler mouse. Proc. Natl. Acad. Sci. U.S.A. 104: 19583-8 [PMID:18048323]

270. Grimm C, Jörs S, Guo Z, Obukhov AG and Heller S. (2012) Constitutive activity of TRPML2 and TRPML3 channels versus activation by low extracellular sodium and small molecules. J. Biol. Chem. 287: 22701-8 [PMID:22753890]

271. Grimm C, Jörs S, Saldanha SA, Obukhov AG, Pan B, Oshima K, Cuajungco MP, Chase P, Hodder P and 
Heller S. (2010) Small molecule activators of TRPML3. Chem. Biol. 17: 135-48 [PMID:20189104]

272. Grimm C, Kraft R, Sauerbruch S, Schultz G and Harteneck C. (2003) Molecular and functional characterization of the melastatin-related cation channel TRPM3. J. Biol. Chem. 278: 21493-501 [PMID:12672799]

273. Grimm C, Kraft R, Schultz G and Harteneck C. (2005) Activation of the melastatin-related cation channel TRPM3 by D-erythro-sphingosine [corrected]. Mol. Pharmacol. 67: 798-805 [PMID:15550678]

274. Gross SA, Guzmán GA, Wissenbach U, Philipp SE, Zhu MX, Bruns D and Cavalié A. (2009) TRPC5 is a Ca2+-activated channel functionally coupled to Ca2+-selective ion channels. J. Biol. Chem. 284: 34423-32 [PMID:19815560]

275. Grubisha O, Rafty LA, Takanishi CL, Xu X, Tong L, Perraud AL, Scharenberg AM and Denu JM. (2006) Metabolite of SIR2 reaction modulates TRPM2 ion channel. J. Biol. Chem. 281: 14057-65 [PMID:16565078]

276. Guinamard R, Chatelier A, Demion M, Potreau D, Patri S, Rahmati M and Bois P. (2004) Functional characterization of a $\mathrm{Ca}(2+)$-activated non-selective cation channel in human atrial cardiomyocytes. $J$. Physiol. (Lond.) 558: 75-83 [PMID:15121803]

277. Guinamard R, Chatelier A, Lenfant $J$ and Bois $P$. (2004) Activation of the $\mathrm{Ca}(2+)$-activated nonselective cation channel by diacylglycerol analogues in rat cardiomyocytes. J. Cardiovasc. Electrophysiol. 15: 342-8 [PMID:15030426]

278. Guinamard R, Sallé $L$ and Simard C. (2011) The non-selective monovalent cationic channels TRPM4 and TRPM5. Adv. Exp. Med. Biol. 704: 147-71 [PMID:21290294]

279. Guler AD, Lee H, lida T, Shimizu I, Tominaga M and Caterina M. (2002) Heat-evoked activation of the ion channel, TRPV4. J. Neurosci. 22: 6408-14 [PMID:12151520]

280. Gunthorpe MJ and Chizh BA. (2009) Clinical development of TRPV1 antagonists: targeting a pivotal point in the pain pathway. Drug Discov. Today 14: 56-67 [PMID:19063991]

281. Gunthorpe MJ, Hannan SL, Smart D, Jerman JC, Arpino S, Smith GD, Brough S, Wright J, Egerton J and Lappin SC et al.. (2007) Characterization of SB-705498, a potent and selective vanilloid receptor-1 (VR1/TRPV1) antagonist that inhibits the capsaicin-, acid-, and heat-mediated activation of the receptor. $J$. Pharmacol. Exp. Ther. 321: 1183-92 [PMID:17392405]

282. Gunthorpe MJ, Rami HK, Jerman JC, Smart D, Gill CH, Soffin EM, Luis Hannan S, Lappin SC, Egerton J and Smith GD et al.. (2004) Identification and characterisation of SB-366791, a potent and selective vanilloid receptor (VR1/TRPV1) antagonist. Neuropharmacology 46: 133-49 [PMID:14654105]

283. Guo L, Chen M, Basora N and Zhou J. (2000) The human polycystic kidney disease 2-like (PKDL) gene: exon/intron structure and evidence for a novel splicing mechanism. Mamm. Genome 11: 46-50 [PMID:10602992]

284. Guo L, Schreiber TH, Weremowicz S, Morton CC, Lee C and Zhou J. (2000) Identification and characterization of a novel polycystin family member, polycystin-L2, in mouse and human: sequence, expression, alternative splicing, and chromosomal localization. Genomics 64: 241-51 [PMID:10756092]

285. Haas ET, Rowland K and Gautam M. (2011) Tooth injury increases expression of the cold sensitive TRP channel TRPA1 in trigeminal neurons. Arch. Oral Biol. 56: 1604-9 [PMID:21783172]

286. Halaszovich CR, Zitt C, Jungling E and Luckhoff A. (2000) Inhibition of TRP3 channels by lanthanides. Block from the cytosolic side of the plasma membrane. J. Biol. Chem. 275: 37423-8 [PMID:10970899]

287. Hamanaka K, Jian MY, Weber DS, Alvarez DF, Townsley MI, Al-Mehdi AB, King JA, Liedtke W and Parker JC. (2007) TRPV4 initiates the acute calcium-dependent permeability increase during ventilator-induced lung injury in isolated mouse lungs. Am. J. Physiol. Lung Cell Mol. Physiol. 293: L923-32 [PMID:17660328]

288. Hanaoka K, Qian F, Boletta A, Bhunia AK, Piontek K, Tsiokas L, Sukhatme VP, Guggino WB and Germino GG. (2000) Co-assembly of polycystin-1 and -2 produces unique cation-permeable currents. Nature 408: 990-4 [PMID:11140688]

289. Hannan MA, Kabbani N, Paspalas CD and Levenson R. (2008) Interaction with dopamine D2 receptor enhances expression of transient receptor potential channel 1 at the cell surface. Biochim. Biophys. Acta 1778: 974-82 [PMID:18261457] 
290. Hansen A and Finger TE. (2008) Is TrpM5 a reliable marker for chemosensory cells? Multiple types of microvillous cells in the main olfactory epithelium of mice. BMC Neurosci 9: 115 [PMID:19055837]

291. Hara Y, Wakamori M, Ishii M, Maeno E, Nishida M, Yoshida T, Yamada H, Shimizu S, Mori E and Kudoh J et al.. (2002) LTRPC2 Ca2+-permeable channel activated by changes in redox status confers susceptibility to cell death. Mol. Cell 9: 163-73 [PMID:11804595]

292. Haraguchi K, Kawamoto A, Isami K, Maeda S, Kusano A, Asakura K, Shirakawa H, Mori Y, Nakagawa T and Kaneko S. (2012) TRPM2 contributes to inflammatory and neuropathic pain through the aggravation of pronociceptive inflammatory responses in mice. J. Neurosci. 32: 3931-41 [PMID:22423113]

293. Harding SD, Sharman JL, Faccenda E, Southan C, Pawson AJ, Ireland S, Gray AJG, Bruce L, Alexander SPH and Anderton S et al.. (2018) The IUPHAR/BPS Guide to PHARMACOLOGY in 2018: updates and expansion to encompass the new guide to IMMUNOPHARMACOLOGY. Nucleic Acids Res. 46: D1091D1106 [PMID:29149325]

294. Harteneck C. (2005) Function and pharmacology of TRPM cation channels.Naunyn Schmiedebergs Arch. Pharmacol. 371: 307-14 [PMID:15843919]

295. Harteneck $C$ and Gollasch M. (2011) Pharmacological modulation of diacylglycerol-sensitive TRPC3/6/7 channels. Curr Pharm Biotechnol 12: 35-41 [PMID:20932261]

296. Hartmann J, Dragicevic E, Adelsberger H, Henning HA, Sumser M, Abramowitz J, Blum R, Dietrich A, Freichel $M$ and Flockerzi $V$ et al.. (2008) TRPC3 channels are required for synaptic transmission and motor coordination. Neuron 59: 392-8 [PMID:18701065]

297. Hata T, Tazawa S, Ohta S, Rhyu MR, Misaka T and Ichihara K. (2012) Artepillin C, a major ingredient of Brazilian propolis, induces a pungent taste by activating TRPA1 channels. PLoS ONE 7: e48072 [PMID:23133611]

298. Hatano N, Itoh Y, Suzuki H, Muraki Y, Hayashi H, Onozaki K, Wood IC, Beech DJ and Muraki K. (2012) Hypoxia-inducible factor-1 $\alpha$ (HIF1 $\alpha$ ) switches on transient receptor potential ankyrin repeat 1 (TRPA1) gene expression via a hypoxia response element-like motif to modulate cytokine release. J. Biol. Chem. 287: 31962-72 [PMID:22843691]

299. Hatano N, Suzuki H, Muraki Y and Muraki K. (2013) Stimulation of human TRPA1 channels by clinical concentrations of the antirheumatic drug auranofin. Am. J. Physiol., Cell Physiol. 304: C354-61 [PMID:23220116]

300. Hayes P, Meadows HJ, Gunthorpe MJ, Harries MH, Duckworth DM, Cairns W, Harrison DC, Clarke CE, Ellington K and Prinjha RK et al.. (2000) Cloning and functional expression of a human orthologue of rat vanilloid receptor-1. Pain 88: 205-15 [PMID:11050376]

301. He LP, Hewavitharana T, Soboloff J, Spassova MA and Gill DL. (2005) A functional link between storeoperated and TRPC channels revealed by the 3,5-bis(trifluoromethyl)pyrazole derivative, BTP2. J. Biol. Chem. 280: 10997-1006 [PMID:15647288]

302. Heeringa SF, Möller CC, Du J, Yue L, Hinkes B, Chernin G, Vlangos CN, Hoyer PF, Reiser J and Hildebrandt F. (2009) A novel TRPC6 mutation that causes childhood FSGS. PLoS ONE 4: e7771 [PMID:19936226]

303. Heiner I, Eisfeld J, Halaszovich CR, Wehage E, Jüngling E, Zitt C and Lückhoff A. (2003) Expression profile of the transient receptor potential (TRP) family in neutrophil granulocytes: evidence for currents through long TRP channel 2 induced by ADP-ribose and NAD. Biochem. J. 371: 1045-53 [PMID:12564954]

304. Hermosura MC, Cui AM, Go RC, Davenport B, Shetler CM, Heizer JW, Schmitz C, Mocz G, Garruto RM and Perraud AL. (2008) Altered functional properties of a TRPM2 variant in Guamanian ALS and PD. Proc. Natt. Acad. Sci. U.S.A. 105: 18029-34 [PMID:19004782]

305. Hermosura MC and Garruto RM. (2007) TRPM7 and TRPM2-Candidate susceptibility genes for Western Pacific ALS and PD? Biochim. Biophys. Acta 1772: 822-35 [PMID:17395433]

306. Hermosura MC, Nayakanti H, Dorovkov MV, Calderon FR, Ryazanov AG, Haymer DS and Garruto RM. (2005) A TRPM7 variant shows altered sensitivity to magnesium that may contribute to the pathogenesis of two Guamanian neurodegenerative disorders. Proc. Natl. Acad. Sci. U.S.A. 102: 11510-5 [PMID:16051700] 
307. Herson PS, Dulock KA and Ashford ML. (1997) Characterization of a nicotinamide-adenine dinucleotidedependent cation channel in the CRI-G1 rat insulinoma cell line. J. Physiol. (Lond.) 505 ( Pt 1): 65-76 [PMID:9409472]

308. Hill K, Benham CD, McNulty S and Randall AD. (2004) Flufenamic acid is a pH-dependent antagonist of TRPM2 channels. Neuropharmacology 47: 450-60 [PMID:15275834]

309. Hill K, McNulty S and Randall AD. (2004) Inhibition of TRPM2 channels by the antifungal agents clotrimazole and econazole. Naunyn Schmiedebergs Arch. Pharmacol. 370: 227-37 [PMID:15549272]

310. Hill K, Tigue NJ, Kelsell RE, Benham CD, McNulty S, Schaefer M and Randall AD. (2006) Characterisation of recombinant rat TRPM2 and a TRPM2-like conductance in cultured rat striatal neurones. Neuropharmacology 50: 89-97 [PMID:16260005]

311. Hinman A, Chuang HH, Bautista DM and Julius D. (2006) TRP channel activation by reversible covalent modification. Proc. Natl. Acad. Sci. U.S.A. 103: 19564-8 [PMID:17164327]

312. Hirnet D, Olausson J, Fecher-Trost C, Bödding M, Nastainczyk W, Wissenbach U, Flockerzi V and Freichel M. (2003) The TRPV6 gene, cDNA and protein. Cell Calcium 33: 509-18 [PMID:12765696]

313. Hiroi T, Wajima T, Negoro T, Ishii M, Nakano Y, Kiuchi Y, Mori Y and Shimizu S. (2013) Neutrophil TRPM2 channels are implicated in the exacerbation of myocardial ischaemia/reperfusion injury. Cardiovasc. Res. 97: 271-81 [PMID:23129587]

314. Hirschi M, Herzik Jr MA, Wie J, Suo Y, Borschel WF, Ren D, Lander GC and Lee SY. (2017) Cryo-electron microscopy structure of the lysosomal calcium-permeable channel TRPML3. Nature 550: 411-414 [PMID:29019979]

315. Hisanaga E, Nagasawa M, Ueki K, Kulkarni RN, Mori M and Kojima I. (2009) Regulation of calciumpermeable TRPV2 channel by insulin in pancreatic beta-cells. Diabetes 58: 174-84 [PMID:18984736]

316. Hoenderop JG, Müller D, Van Der Kemp AW, Hartog A, Suzuki M, Ishibashi K, Imai M, Sweep F, Willems $\mathrm{PH}$ and Van Os CH et al.. (2001) Calcitriol controls the epithelial calcium channel in kidney.J. Am. Soc. Nephrol. 12: 1342-9 [PMID:11423563]

317. Hoenderop JG, van Leeuwen JP, van der Eerden BC, Kersten FF, van der Kemp AW, MÃ@rillat AM, Waarsing JH, Rossier BC, Vallon V, Hummler E and Bindels RJ. (2003) Renal Ca2+ wasting, hyperabsorption, and reduced bone thickness in mice lacking TRPV5. J. Clin. Invest. 112: 1906-14 [PMID:14679186]

318. Hoenderop JG, Vennekens R, Müller D, Prenen J, Droogmans G, Bindels RJ and Nilius B. (2001) Function and expression of the epithelial $\mathrm{Ca}(2+)$ channel family: comparison of mammalian $\mathrm{ECaC} 1$ and 2. J. Physiol. (Lond.) 537: 747-61 [PMID:11744752]

319. Hoenderop JG, Voets T, Hoefs S, Weidema F, Prenen J, Nilius B and Bindels RJ. (2003) Homo- and heterotetrameric architecture of the epithelial Ca2+ channels TRPV5 and TRPV6. EMBO J. 22: 776-85 [PMID:12574114]

320. Hofherr A and Köttgen M. (2011) TRPP channels and polycystins. Adv. Exp. Med. Biol. 704: 287-313 [PMID:21290302]

321. Hofmann T, Chubanov V, Gudermann T and Montell C. (2003) TRPM5 is a voltage-modulated and $\mathrm{Ca}(2+)$-activated monovalent selective cation channel. Curr. Biol. 13: 1153-8 [PMID:12842017]

322. Hofmann T, Obukhov AG, Schaefer M, Harteneck C, Gudermann T and Schultz G. (1999) Direct activation of human TRPC6 and TRPC3 channels by diacylglycerol. Nature 397: 259-63 [PMID:9930701]

323. Hofmann T, Schaefer M, Schultz G and Gudermann T. (2000) Cloning, expression and subcellular localization of two novel splice variants of mouse transient receptor potential channel 2. Biochem. J. 351: 115-22 [PMID:10998353]

324. Holakovska B, Grycova L, Bily J and Teisinger J. (2011) Characterization of calmodulin binding domains in TRPV2 and TRPV5 C-tails. Amino Acids 40: 741-8 [PMID:20686800]

325. Hox V, Vanoirbeek JA, Alpizar YA, Voedisch S, Callebaut I, Bobic S, Sharify A, De Vooght V, Van Gerven $L$ and Devos $F$ et al.. (2013) Crucial role of transient receptor potential ankyrin 1 and mast cells in induction of nonallergic airway hyperreactivity in mice. Am. J. Respir. Crit. Care Med. 187: 486-93 [PMID:23262517]

326. Hu H, Bandell M, Petrus MJ, Zhu MX and Patapoutian A. (2009) Zinc activates damage-sensing TRPA1 
ion channels. Nat. Chem. Biol. 5: 183-90 [PMID:19202543]

327. Hu H, Tian J, Zhu Y, Wang C, Xiao R, Herz JM, Wood JD and Zhu MX. (2010) Activation of TRPA1 channels by fenamate nonsteroidal anti-inflammatory drugs. Pflugers Arch. 459: 579-92 [PMID:19888597]

328. Hu HZ, Gu Q, Wang C, Colton CK, Tang J, Kinoshita-Kawada M, Lee LY, Wood JD and Zhu MX. (2004) 2aminoethoxydiphenyl borate is a common activator of TRPV1, TRPV2, and TRPV3. J. Biol. Chem. 279: 35741-8 [PMID:15194687]

329. Huang AL, Chen X, Hoon MA, Chandrashekar J, Guo W, Tränkner D, Ryba NJ and Zuker CS. (2006) The cells and logic for mammalian sour taste detection. Nature 442: 934-8 [PMID:16929298]

330. Huang GN, Zeng W, Kim JY, Yuan JP, Han L, Muallem S and Worley PF. (2006) STIM1 carboxyl-terminus activates native SOC, I(crac) and TRPC1 channels. Nat. Cell Biol. 8: 1003-10 [PMID:16906149]

331. Huang SM, Lee H, Chung MK, Park U, Yu YY, Bradshaw HB, Coulombe PA, Walker JM and Caterina MJ. (2008) Overexpressed transient receptor potential vanilloid 3 ion channels in skin keratinocytes modulate pain sensitivity via prostaglandin E2. J. Neurosci. 28: 13727-37 [PMID:19091963]

332. Huang YA and Roper SD. (2010) Intracellular $\mathrm{Ca}(2+)$ and TRPM5-mediated membrane depolarization produce ATP secretion from taste receptor cells. J. Physiol. (Lond.) 588: 2343-50 [PMID:20498227]

333. Hui H, McHugh D, Hannan M, Zeng F, Xu SZ, Khan SU, Levenson R, Beech DJ and Weiss JL. (2006) Calcium-sensing mechanism in TRPC5 channels contributing to retardation of neurite outgrowth. $J$. Physiol. (Lond.) 572: 165-72 [PMID:16469785]

334. Hui K, Guo Y and Feng ZP. (2005) Biophysical properties of menthol-activated cold receptor TRPM8 channels. Biochem. Biophys. Res. Commun. 333: 374-82 [PMID:15950184]

335. Hunter JJ, Shao J, Smutko JS, Dussault BJ, Nagle DL, Woolf EA, Holmgren LM, Moore KJ and Shyjan AW. (1998) Chromosomal localization and genomic characterization of the mouse melastatin gene (Mlsn1). Genomics 54: 116-23 [PMID:9806836]

336. Hurne AM, Chai CL, Moerman K and Waring P. (2002) Influx of calcium through a redox-sensitive plasma membrane channel in thymocytes causes early necrotic cell death induced by the epipolythiodioxopiperazine toxins. J. Biol. Chem. 277: 31631-8 [PMID:12063251]

337. Hwang SW, Cho H, Kwak J, Lee SY, Kang CJ, Jung J, Cho S, Min KH, Suh YG and Kim Det al.. (2000) Direct activation of capsaicin receptors by products of lipoxygenases: endogenous capsaicin-like substances. Proc. Natl. Acad. Sci. U.S.A. 97: 6155-60 [PMID:10823958]

338. Häfner S, Burg F, Kannler M, Urban N, Mayer P, Dietrich A, Trauner D, Broichhagen J and Schaefer M. (2018) A (+)-Larixol Congener with High Affinity and Subtype Selectivity toward TRPC6. ChemMedChem 13: 1028-1035 [PMID:29522264]

339. Inada $\mathrm{H}$, lida $\mathrm{T}$ and Tominaga M. (2006) Different expression patterns of TRP genes in murine $B$ and $T$ lymphocytes. Biochem. Biophys. Res. Commun. 350: 762-7 [PMID:17027915]

340. Inoue R, Okada T, Onoue H, Hara Y, Shimizu S, Naitoh S, Ito Y and Mori Y. (2001) The transient receptor potential protein homologue TRP6 is the essential component of vascular alpha(1)-adrenoceptor-activated $\mathrm{Ca}(2+)$-permeable cation channel. Circ. Res. 88: 325-32 [PMID:11179201]

341. Irie S and Furukawa T. (2014) TRPM1. Handb Exp Pharmacol 222: 387-402 [PMID:24756714]

342. Irnaten M, Blanchard-Gutton N, Praetorius J and Harvey BJ. (2009) Rapid effects of 17beta-estradiol on TRPV5 epithelial Ca2+ channels in rat renal cells. Steroids 74: 642-9 [PMID:19463684]

343. Ishimaru $Y$, Inada $H$, Kubota M, Zhuang H, Tominaga M and Matsunami H. (2006) Transient receptor potential family members PKD1L3 and PKD2L1 form a candidate sour taste receptor. Proc. Natl. Acad. Sci. U.S.A. 103: 12569-74 [PMID:16891422]

344. Islam MS. (2011) TRP channels of islets.Adv. Exp. Med. Biol. 704: 811-30 [PMID:21290328]

345. Iwata Y, Katanosaka Y, Arai Y, Komamura K, Miyatake K and Shigekawa M. (2003) A novel mechanism of myocyte degeneration involving the Ca2+-permeable growth factor-regulated channel. J. Cell Biol. 161: 957-67 [PMID:12796481]

346. Iwata Y, Katanosaka Y, Arai Y, Shigekawa M and Wakabayashi S. (2009) Dominant-negative inhibition of $\mathrm{Ca} 2+$ influx via TRPV2 ameliorates muscular dystrophy in animal models. Hum. Mol. Genet. 18: 824-34 [PMID:19050039] 
347. Jacobs G, Oosterlinck W, Dresselaers T, Geenens R, Kerselaers S, Himmelreich U, Herijgers P and Vennekens R. (2015) Enhanced $\beta$-adrenergic cardiac reserve in Trpm4 $/$ - mice with ischaemic heart failure. Cardiovasc. Res. 105: 330-9 [PMID:25600961]

348. Jang Y, Lee Y, Kim SM, Yang YD, Jung J and Oh U. (2012) Quantitative analysis of TRP channel genes in mouse organs. Arch. Pharm. Res. 35: 1823-30 [PMID:23139135]

349. Janssen SW, Hoenderop JG, Hermus AR, Sweep FC, Martens GJ and Bindels RJ. (2002) Expression of the novel epithelial $\mathrm{Ca} 2+$ channel $\mathrm{ECaC} 1$ in rat pancreatic islets. J. Histochem. Cytochem. 50: 789-98 [PMID:12019295]

350. Jaquemar D, Schenker T and Trueb B. (1999) An ankyrin-like protein with transmembrane domains is specifically lost after oncogenic transformation of human fibroblasts. J. Biol. Chem. 274: 7325-33 [PMID:10066796]

351. Jeon JP, Hong C, Park EJ, Jeon JH, Cho NH, Kim IG, Choe H, Muallem S, Kim HJ and So I. (2012) Selective Gai subunits as novel direct activators of transient receptor potential canonical (TRPC) 4 and TRPC5 channels. J. Biol. Chem. 287: 17029-39 [PMID:22457348]

352. Jerman JC, Brough SJ, Prinjha R, Harries MH, Davis JB and Smart D. (2000) Characterization using FLIPR of rat vanilloid receptor (rVR1) pharmacology. Br. J. Pharmacol. 130: 916-22 [PMID:10864900]

353. Jia Y, Wang X, Varty L, Rizzo CA, Yang R, Correll CC, Phelps PT, Egan RW and Hey JA. (2004) Functional TRPV4 channels are expressed in human airway smooth muscle cells. Am. J. Physiol. Lung Cell Mol. Physiol. 287: L272-8 [PMID:15075247]

354. Jiang J, Li M and Yue L. (2005) Potentiation of TRPM7 inward currents by protonsJ. Gen. Physiol. 126: 137-50 [PMID:16009728]

355. Jin J, Desai BN, Navarro B, Donovan A, Andrews NC and Clapham DE. (2008) Deletion of Trpm7 disrupts embryonic development and thymopoiesis without altering Mg2+ homeostasis. Science 322: 756-60 [PMID:18974357]

356. Jordt SE, Bautista DM, Chuang HH, McKemy DD, Zygmunt PM, Högestätt ED, Meng ID and Julius D. (2004) Mustard oils and cannabinoids excite sensory nerve fibres through the TRP channel ANKTM1. Nature 427: 260-5 [PMID:14712238]

357. Jung S, Mühle A, Schaefer M, Strotmann R, Schultz G and Plant TD. (2003) Lanthanides potentiate TRPC5 currents by an action at extracellular sites close to the pore mouth. J. Biol. Chem. 278: 3562-71 [PMID:12456670]

358. Juvin V, Penna A, Chemin J, Lin YL and Rassendren FA. (2007) Pharmacological characterization and molecular determinants of the activation of transient receptor potential V2 channel orthologs by 2aminoethoxydiphenyl borate. Mol. Pharmacol. 72: 1258-68 [PMID:17673572]

359. Kaczmarek JS, Riccio A and Clapham DE. (2012) Calpain cleaves and activates the TRPC5 channel to participate in semaphorin 3A-induced neuronal growth cone collapse. Proc. Natl. Acad. Sci. U.S.A. 109: 7888-92 [PMID:22547824]

360. Kajiya H, Okamoto F, Nemoto T, Kimachi K, Toh-Goto K, Nakayana S and Okabe K. (2010) RANKLinduced TRPV2 expression regulates osteoclastogenesis via calcium oscillations. Cell Calcium 48: 260-9 [PMID:20980052]

361. Kaneko S, Kawakami S, Hara Y, Wakamori M, Itoh E, Minami T, Takada Y, Kume T, Katsuki H and Mori Y et al.. (2006) A critical role of TRPM2 in neuronal cell death by hydrogen peroxide J. Pharmacol. Sci. 101: 66-76 [PMID:16651700]

362. Kanzaki M, Zhang YQ, Mashima H, Li L, Shibata H and Kojima I. (1999) Translocation of a calciumpermeable cation channel induced by insulin-like growth factor-I. Nat. Cell Biol. 1: 165-70 [PMID:10559903]

363. Karacsonyi C, Miguel AS and Puertollano R. (2007) Mucolipin-2 localizes to the Arf6-associated pathway and regulates recycling of GPI-APs. Traffic 8: 1404-14 [PMID:17662026]

364. Karashima Y, Damann N, Prenen J, Talavera K, Segal A, Voets T and Nilius B. (2007) Bimodal action of menthol on the transient receptor potential channel TRPA1. J. Neurosci. 27: 9874-84 [PMID:17855602]

365. Karashima Y, Talavera K, Everaerts W, Janssens A, Kwan KY, Vennekens R, Nilius B and Voets T. (2009) TRPA1 acts as a cold sensor in vitro and in vivo. Proc. Natl. Acad. Sci. U.S.A. 106: 1273-8 
[PMID:19144922]

366. Kashio M, Sokabe T, Shintaku K, Uematsu T, Fukuta N, Kobayashi N, Mori Y and Tominaga M. (2012) Redox signal-mediated sensitization of transient receptor potential melastatin 2 (TRPM2) to temperature affects macrophage functions. Proc. Natl. Acad. Sci. U.S.A. 109: 6745-50 [PMID:22493272]

367. Katano M, Numata T, Aguan K, Hara Y, Kiyonaka S, Yamamoto S, Miki T, Sawamura S, Suzuki T and Yamakawa K et al.. (2012) The juvenile myoclonic epilepsy-related protein EFHC1 interacts with the redox-sensitive TRPM2 channel linked to cell death. Cell Calcium 51: 179-85 [PMID:22226147]

368. Kato AS, Knierman MD, Siuda ER, Isaac JT, Nisenbaum ES and Bredt DS. (2012) Glutamate receptor $\delta 2$ associates with metabotropic glutamate receptor 1 (mGluR1), protein kinase $\mathrm{C}_{\gamma}$, and canonical transient receptor potential 3 and regulates mGluR1-mediated synaptic transmission in cerebellar Purkinje neurons. J. Neurosci. 32: 15296-308 [PMID:23115168]

369. Katsura H, Obata K, Mizushima T, Sakurai J, Kobayashi K, Yamanaka H, Dai Y, Fukuoka T, Sakagami M and Noguchi K. (2007) Activation of extracellular signal-regulated protein kinases 5 in primary afferent neurons contributes to heat and cold hyperalgesia after inflammation. J. Neurochem. 102: 1614-24 [PMID:17573825]

370. Katsura H, Obata K, Mizushima T, Yamanaka H, Kobayashi K, Dai Y, Fukuoka T, Tokunaga A, Sakagami $M$ and Noguchi K. (2006) Antisense knock down of TRPA1, but not TRPM8, alleviates cold hyperalgesia after spinal nerve ligation in rats. Exp. Neurol. 200: 112-23 [PMID:16546170]

371. Kerschbaum HH, Kozak JA and Cahalan MD. (2003) Polyvalent cations as permeant probes of MIC and TRPM7 pores. Biophys. J. 84: 2293-305 [PMID:12668438]

372. Khairatkar-Joshi N, Shah DM, Mukhopadhyay I, Lingam VS and Thomas A. (2015) TRPC channel modulators and their potential therapeutic applications. Pharm Pat Anal 4: 207-18 [PMID:26030081]

373. Kim HJ, Li Q, Tjon-Kon-Sang S, So I, Kiselyov K and Muallem S. (2007) Gain-of-function mutation in TRPML3 causes the mouse Varitint-Waddler phenotype. J. Biol. Chem. 282: 36138-42 [PMID:17962195]

374. Kim HJ, Li Q, Tjon-Kon-Sang S, So I, Kiselyov K, Soyombo AA and Muallem S. (2008) A novel mode of TRPML3 regulation by extracytosolic $\mathrm{pH}$ absent in the varitint-waddler phenotype. EMBO J. 27: 1197-205 [PMID:18369318]

375. Kim HJ, Soyombo AA, Tjon-Kon-Sang S, So I and Muallem S. (2009) The Ca(2+) channel TRPML3 regulates membrane trafficking and autophagy. Traffic 10: 1157-67 [PMID:19522758]

376. Kim S-Y, Kim JK, Lee K-W, Woo BY, Shin SS, Moh J-H, Kim S-il, Jeong YS, Lim KM and Choi JKet al.. (2010) Compounds, isomer thereof, or pharmaceutically acceptable salts thereof as vanilloid receptor antagonist; and pharmaceutical compositions containing the same Patent number: US7858621.

377. Kim SJ, Kim YS, Yuan JP, Petralia RS, Worley PF and Linden DJ. (2003) Activation of the TRPC1 cation channel by metabotropic glutamate receptor mGluR1. Nature 426: 285-91 [PMID:14614461]

378. Kim W, Bennett EJ, Huttlin EL, Guo A, Li J, Possemato A, Sowa ME, Rad R, Rush J and Comb MÆt al.. (2011) Systematic and quantitative assessment of the ubiquitin-modified proteome. Mol. Cell 44: 325-40 [PMID:21906983]

379. Kim YS, Kang E, Makino Y, Park S, Shin JH, Song H, Launay P and Linden DJ. (2013) Characterizing the conductance underlying depolarization-induced slow current in cerebellar Purkinje cells. J. Neurophysiol. 109: 1174-81 [PMID:23197456]

380. Kimball ES, Prouty SP, Pavlick KP, Wallace NH, Schneider CR and Hornby PJ. (2007) Stimulation of neuronal receptors, neuropeptides and cytokines during experimental oil of mustard colitis.

Neurogastroenterol. Motil. 19: 390-400 [PMID:17509021]

381. Kinoshita-Kawada M, Tang J, Xiao R, Kaneko S, Foskett JK and Zhu MX. (2005) Inhibition of TRPC5 channels by Ca2+-binding protein 1 in Xenopus oocytes. Pflugers Arch. 450: 345-54 [PMID:15895247]

382. Kiselyov K and Patterson RL. (2009) The integrative function of TRPC channels. Front. Biosci. 14: 45-58 [PMID:19273053]

383. Kiselyov K, Shin DM, Kim JY, Yuan JP and Muallem S. (2007) TRPC channels: interacting proteins. Handb Exp Pharmacol 559-74 [PMID:17217079]

384. Kiselyov K, Soyombo A and Muallem S. (2007) TRPpathies.J. Physiol. (Lond.) 578: 641-53 
[PMID:17138610]

385. Kitaguchi T and Swartz KJ. (2005) An inhibitor of TRPV1 channels isolated from funnel Web spider venom. Biochemistry 44: 15544-9 [PMID:16300403]

386. Kiyonaka S, Kato K, Nishida M, Mio K, Numaga T, Sawaguchi Y, Yoshida T, Wakamori M, Mori E and Numata T et al.. (2009) Selective and direct inhibition of TRPC3 channels underlies biological activities of a pyrazole compound. Proc. Natl. Acad. Sci. U.S.A. 106: 5400-5 [PMID:19289841]

387. Klausen TK, Pagani A, Minassi A, Ech-Chahad A, Prenen J, Owsianik G, Hoffmann EK, Pedersen SF, Appendino $G$ and Nilius B. (2009) Modulation of the transient receptor potential vanilloid channel TRPV4 by 4alpha-phorbol esters: a structure-activity study. J. Med. Chem. 52: 2933-9 [PMID:19361196]

388. Klooster J, Blokker J, Ten Brink JB, Unmehopa U, Fluiter K, Bergen AA and Kamermans M. (2011) Ultrastructural localization and expression of TRPM1 in the human retina. Invest. Ophthalmol. Vis. Sci. 52: 8356-62 [PMID:21896854]

389. Klose C, Straub I, Riehle M, Ranta F, Krautwurst D, Ullrich S, Meyerhof W and Harteneck C. (2011) Fenamates as TRP channel blockers: mefenamic acid selectively blocks TRPM3. Br. J. Pharmacol. 162: 1757-69 [PMID:21198543]

390. Knowlton WM, Daniels RL, Palkar R, McCoy DD and McKemy DD. (2011) Pharmacological blockade of TRPM8 ion channels alters cold and cold pain responses in mice. PLOS ONE 6: e25894 [PMID:21984952]

391. Knowlton WM and McKemy DD. (2011) TRPM8: from cold to cancer, peppermint to pain.Curr Pharm Biotechnol 12: 68-77 [PMID:20932257]

392. Kobayashi K, Fukuoka T, Obata K, Yamanaka H, Dai Y, Tokunaga A and Noguchi K. (2005) Distinct expression of TRPM8, TRPA1, and TRPV1 mRNAs in rat primary afferent neurons with adelta/c-fibers and colocalization with trk receptors. J. Comp. Neurol. 493: 596-606 [PMID:16304633]

393. Kobori T, Smith GD, Sandford R and Edwardson JM. (2009) The transient receptor potential channels TRPP2 and TRPC1 form a heterotetramer with a 2:2 stoichiometry and an alternating subunit arrangement. J. Biol. Chem. 284: 35507-13 [PMID:19850920]

394. Koch SE, Gao X, Haar L, Jiang M, Lasko VM, Robbins N, Cai W, Brokamp C, Varma P and Tranter Met al.. (2012) Probenecid: novel use as a non-injurious positive inotrope acting via cardiac TRPV2 stimulation. J. Mol. Cell. Cardiol. 53: 134-44 [PMID:22561103]

395. Kochukov MY, Balasubramanian A, Noel RC and Marrelli SP. (2013) Role of TRPC1 and TRPC3 channels in contraction and relaxation of mouse thoracic aorta. J. Vasc. Res. 50: 11-20 [PMID:23095462]

396. Koike C, Obara T, Uriu Y, Numata T, Sanuki R, Miyata K, Koyasu T, Ueno S, Funabiki K and Tani At al.. (2010) TRPM1 is a component of the retinal ON bipolar cell transduction channel in the mGluR6 cascade. Proc Natl Acad Sci U S A 107: 332-337 [PMID:19966281]

397. Koivisto A, Hukkanen M, Saarnilehto M, Chapman H, Kuokkanen K, Wei H, Viisanen H, Akerman KE, Lindstedt K and Pertovaara A. (2012) Inhibiting TRPA1 ion channel reduces loss of cutaneous nerve fiber function in diabetic animals: sustained activation of the TRPA1 channel contributes to the pathogenesis of peripheral diabetic neuropathy. Pharmacol. Res. 65: 149-58 [PMID:22133672]

398. Kolisek M, Beck A, Fleig A and Penner R. (2005) Cyclic ADP-ribose and hydrogen peroxide synergize with ADP-ribose in the activation of TRPM2 channels. Mol. Cell 18: 61-9 [PMID:15808509]

399. Kondo M, Sanuki R, Ueno S, Nishizawa Y, Hashimoto N, Ohguro H, Yamamoto S, Machida S, Terasaki H and Adamus $G$ et al.. (2011) Identification of autoantibodies against TRPM1 in patients with paraneoplastic retinopathy associated with ON bipolar cell dysfunction. PLOS ONE 6: e19911 [PMID:21611200]

400. Kono T, Kaneko A, Omiya Y, Ohbuchi K, Ohno N and Yamamoto M. (2013) Epithelial transient receptor potential ankyrin 1 (TRPA1)-dependent adrenomedullin upregulates blood flow in rat small intestine. Am. J. Physiol. Gastrointest. Liver Physiol. 304: G428-36 [PMID:23275609]

401. Kosugi M, Nakatsuka T, Fujita T, Kuroda Y and Kumamoto E. (2007) Activation of TRPA1 channel facilitates excitatory synaptic transmission in substantia gelatinosa neurons of the adult rat spinal cord. J. Neurosci. 27: 4443-51 [PMID:17442829]

402. Koulen P, Cai Y, Geng L, Maeda Y, Nishimura S, Witzgall R, Ehrlich BE and Somlo S. (2002) Polycystin-2 is an intracellular calcium release channel. Nat. Cell Biol. 4: 191-7 [PMID:11854751] 
403. Kozak JA, Kerschbaum HH and Cahalan MD. (2002) Distinct properties of CRAC and MIC channels in RBL cells. J. Gen. Physiol. 120: 221-35 [PMID:12149283]

404. Kozak JA, Matsushita M, Nairn AC and Cahalan MD. (2005) Charge screening by internal pH and polyvalent cations as a mechanism for activation, inhibition, and rundown of TRPM7/MIC channels. J. Gen. Physiol. 126: 499-514 [PMID:16260839]

405. Kraft R. (2007) The Na+/Ca2+ exchange inhibitor KB-R7943 potently blocks TRPC channels.Biochem. Biophys. Res. Commun. 361: 230-6 [PMID:17658472]

406. Kraft R, Grimm C, Frenzel $H$ and Harteneck C. (2006) Inhibition of TRPM2 cation channels by N-(pamylcinnamoyl)anthranilic acid. Br. J. Pharmacol. 148: 264-73 [PMID:16604090]

407. Kraft R, Grimm C, Grosse K, Hoffmann A, Sauerbruch S, Kettenmann H, Schultz G and Harteneck C. (2004) Hydrogen peroxide and ADP-ribose induce TRPM2-mediated calcium influx and cation currents in microglia. Am. J. Physiol., Cell Physiol. 286: C129-37 [PMID:14512294]

408. Kraft $R$ and Harteneck C. (2005) The mammalian melastatin-related transient receptor potential cation channels: an overview. Pflugers Arch. 451: 204-11 [PMID:15895246]

409. Krakow D, Vriens J, Camacho N, Luong P, Deixler H, Funari TL, Bacino CA, Irons MB, Holm IA and Sadler $L$ et al.. (2009) Mutations in the gene encoding the calcium-permeable ion channel TRPV4 produce spondylometaphyseal dysplasia, Kozlowski type and metatropic dysplasia. Am. J. Hum. Genet. 84: 307-15 [PMID:19232556]

410. Krapivinsky G, Mochida S, Krapivinsky L, Cibulsky SM and Clapham DE. (2006) The TRPM7 ion channel functions in cholinergic synaptic vesicles and affects transmitter release. Neuron 52: 485-96 [PMID:17088214]

411. Kremeyer B, Lopera F, Cox JJ, Momin A, Rugiero F, Marsh S, Woods CG, Jones NG, Paterson KJ and Fricker FR et al.. (2010) A gain-of-function mutation in TRPA1 causes familial episodic pain syndrome. Neuron 66: 671-80 [PMID:20547126]

412. Kudoh J, Nagamine K, Asakawa S, Abe I, Kawasaki K, Maeda H, Tsujimoto S, Minoshima S, Ito F and Shimizu N. (1997) Localization of 16 exons to a 450-kb region involved in the autoimmune polyglandular disease type I (APECED) on human chromosome 21q22.3. DNA Res. 4: 45-52 [PMID:9179495]

413. Kun J, Perkecz A, Knie L, Sétáló Jr G, Tornóczki T, Pintér E and Bán Á. (2017) TRPA1 receptor is upregulated in human oral lichen planus. Oral Dis 23: 189-198 [PMID:27718297]

414. Kunert-Keil $\mathrm{C}$, Bisping $F$, Krüger $\mathrm{J}$ and Brinkmeier $\mathrm{H}$. (2006) Tissue-specific expression of TRP channel genes in the mouse and its variation in three different mouse strains. BMC Genomics 7: 159 [PMID:16787531]

415. Kunkler PE, Ballard CJ, Oxford GS and Hurley JH. (2011) TRPA1 receptors mediate environmental irritantinduced meningeal vasodilatation. Pain 152: 38-44 [PMID:21075522]

416. Kuras Z, Yun YH, Chimote AA, Neumeier L and Conforti L. (2012) KCa3.1 and TRPM7 channels at the uropod regulate migration of activated human T cells. PLoS ONE 7: e43859 [PMID:22952790]

417. Kusudo T, Wang Z, Mizuno A, Suzuki M and Yamashita H. (2012) TRPV4 deficiency increases skeletal muscle metabolic capacity and resistance against diet-induced obesity. J. Appl. Physiol. 112: 1223-32 [PMID:22207724]

418. Kwan KY, Allchorne AJ, Vollrath MA, Christensen AP, Zhang DS, Woolf CJ and Corey DP. (2006) TRPA1 contributes to cold, mechanical, and chemical nociception but is not essential for hair-cell transduction. Neuron 50: 277-89 [PMID:16630838]

419. Kwan KY, Glazer JM, Corey DP, Rice FL and Stucky CL. (2009) TRPA1 modulates mechanotransduction in cutaneous sensory neurons. J. Neurosci. 29: 4808-19 [PMID:19369549]

420. Kühn FJ, Heiner I and Lückhoff A. (2005) TRPM2: a calcium influx pathway regulated by oxidative stress and the novel second messenger ADP-ribose. Pflugers Arch. 451: 212-9 [PMID:15952035]

421. Lamandé SR, Yuan Y, Gresshoff IL, Rowley L, Belluoccio D, Kaluarachchi K, Little CB, Botzenhart E, Zerres K and Amor DJ et al.. (2011) Mutations in TRPV4 cause an inherited arthropathy of hands and feet. Nat. Genet. 43: 1142-6 [PMID:21964574]

422. Lambers TT, Mahieu F, Oancea E, Hoofd L, de Lange F, Mensenkamp AR, Voets T, Nilius B, Clapham DE 
and Hoenderop JG et al.. (2006) Calbindin-D28K dynamically controls TRPV5-mediated Ca2+ transport. EMBO J. 25: 2978-88 [PMID:16763551]

423. Lambers TT, Weidema AF, Nilius B, Hoenderop JG and Bindels RJ. (2004) Regulation of the mouse epithelial Ca2(+) channel TRPV6 by the Ca(2+)-sensor calmodulin. J. Biol. Chem. 279: 28855-61 [PMID:15123711]

424. Lambert S, Drews A, Rizun O, Wagner TF, Lis A, Mannebach S, Plant S, Portz M, Meissner M and Philipp SE et al.. (2011) Transient receptor potential melastatin 1 (TRPM1) is an ion-conducting plasma membrane channel inhibited by zinc ions. J. Biol. Chem. 286: 12221-33 [PMID:21278253]

425. Landouré G, Zdebik AA, Martinez TL, Burnett BG, Stanescu HC, Inada H, Shi $Y$, Taye AA, Kong L and Munns CH et al.. (2010) Mutations in TRPV4 cause Charcot-Marie-Tooth disease type 2C.Nat. Genet. 42: 170-4 [PMID:20037586]

426. Lange I, Penner R, Fleig A and Beck A. (2008) Synergistic regulation of endogenous TRPM2 channels by adenine dinucleotides in primary human neutrophils. Cell Calcium 44: 604-15 [PMID:18572241]

427. Lange I, Yamamoto S, Partida-Sanchez S, Mori Y, Fleig A and Penner R. (2009) TRPM2 functions as a lysosomal Ca2+-release channel in beta cells. Sci Signal2: ra23 [PMID:19454650]

428. LaPlante JM, Falardeau J, Sun M, Kanazirska M, Brown EM, Slaugenhaupt SA and Vassilev PM. (2002) Identification and characterization of the single channel function of human mucolipin-1 implicated in mucolipidosis type IV, a disorder affecting the lysosomal pathway. FEBS Lett. 532: 183-7 [PMID:12459486]

429. LaPlante JM, Sun M, Falardeau J, Dai D, Brown EM, Slaugenhaupt SA and Vassilev PM. (2006) Lysosomal exocytosis is impaired in mucolipidosis type IV. Mol. Genet. Metab. 89: 339-48 [PMID:16914343]

430. LaPlante JM, Ye CP, Quinn SJ, Goldin E, Brown EM, Slaugenhaupt SA and Vassilev PM. (2004) Functional links between mucolipin-1 and Ca2+-dependent membrane trafficking in mucolipidosis IV. Biochem. Biophys. Res. Commun. 322: 1384-91 [PMID:15336987]

431. Lashinger ES, Steiginga MS, Hieble JP, Leon LA, Gardner SD, Nagilla R, Davenport EA, Hoffman BE, Laping NJ and Su X. (2008) AMTB, a TRPM8 channel blocker: evidence in rats for activity in overactive bladder and painful bladder syndrome. Am. J. Physiol. Renal Physiol. 295: F803-10 [PMID:18562636]

432. Launay P, Cheng H, Srivatsan S, Penner R, Fleig A and Kinet JP. (2004) TRPM4 regulates calcium oscillations after T cell activation. Science 306: 1374-7 [PMID:15550671]

433. Launay P, Fleig A, Perraud AL, Scharenberg AM, Penner R and Kinet JP. (2002) TRPM4 is a Ca2+activated nonselective cation channel mediating cell membrane depolarization. Cell 109: 397-407 [PMID:12015988]

434. Lee KP, Jun JY, Chang IY, Suh SH, So I and Kim KW. (2005) TRPC4 is an essential component of the nonselective cation channel activated by muscarinic stimulation in mouse visceral smooth muscle cells. Mol. Cells 20: 435-41 [PMID:16404161]

435. Lee N, Chen J, Sun L, Wu S, Gray KR, Rich A, Huang M, Lin JH, Feder JN and Janovitz EBet al.. (2003) Expression and characterization of human transient receptor potential melastatin 3 (hTRPM3). J. Biol. Chem. 278: 20890-7 [PMID:12672827]

436. Lee SP, Buber MT, Yang Q, Cerne R, Cortés RY, Sprous DG and Bryant RW. (2008) Thymol and related alkyl phenols activate the hTRPA1 channel. Br. J. Pharmacol. 153: 1739-49 [PMID:18334983]

437. Lee YM, Kim BJ, Kim HJ, Yang DK, Zhu MH, Lee KP, So I and Kim KW. (2003) TRPC5 as a candidate for the nonselective cation channel activated by muscarinic stimulation in murine stomach. Am. J. Physiol. Gastrointest. Liver Physiol. 284: G604-16 [PMID:12631560]

438. Leffler A, Lattrell A, Kronewald S, Niedermirtl F and Nau C. (2011) Activation of TRPA1 by membrane permeable local anesthetics. Mol Pain 7: 62 [PMID:21861907]

439. Lei YT, Thuault SJ, Launay P, Margolskee RF, Kandel ER and Siegelbaum SA. (2014) Differential contribution of TRPM4 and TRPM5 nonselective cation channels to the slow afterdepolarization in mouse prefrontal cortex neurons. Front Cell Neurosci 8: 267 [PMID:25237295]

440. Leonelli M, Martins DO, Kihara AH and Britto LR. (2009) Ontogenetic expression of the vanilloid receptors 
TRPV1 and TRPV2 in the rat retina. Int. J. Dev. Neurosci. 27: 709-18 [PMID:19619635]

441. Leuner K, Heiser JH, Derksen S, Mladenov MI, Fehske CJ, Schubert R, Gollasch M, Schneider G, Harteneck C and Chatterjee SS et al.. (2010) Simple 2,4-diacylphloroglucinols as classic transient receptor potential-6 activators--identification of a novel pharmacophore. Mol. Pharmacol. 77: 368-77 [PMID:20008516]

442. Leuner K, Kazanski V, Müller M, Essin K, Henke B, Gollasch M, Harteneck C and Müller WE. (2007) Hyperforin--a key constituent of St. John's wort specifically activates TRPC6 channels. FASEB J. 21: 410111 [PMID:17666455]

443. Lev S, Zeevi DA, Frumkin A, Offen-Glasner V, Bach G and Minke B. (2010) Constitutive activity of the human TRPML2 channel induces cell degeneration. J. Biol. Chem. 285: 2771-82 [PMID:19940139]

444. Lewinter RD, Skinner K, Julius D and Basbaum Al. (2004) Immunoreactive TRPV-2 (VRL-1), a capsaicin receptor homolog, in the spinal cord of the rat. J. Comp. Neurol. 470: 400-8 [PMID:14961565]

445. Li HS, Xu XZ and Montell C. (1999) Activation of a TRPC3-dependent cation current through the neurotrophin BDNF. Neuron 24: 261-73 [PMID:10677043]

446. Li M, Jiang $\mathrm{J}$ and Yue L. (2006) Functional characterization of homo- and heteromeric channel kinases TRPM6 and TRPM7. J. Gen. Physiol. 127: 525-37 [PMID:16636202]

447. Li Q, Dai Y, Guo L, Liu Y, Hao C, Wu G, Basora N, Michalak M and Chen XZ. (2003) Polycystin-2 associates with tropomyosin-1, an actin microfilament component. J. Mol. Biol. 325: 949-62 [PMID:12527301]

448. Li Q, Montalbetti N, Shen PY, Dai XQ, Cheeseman Cl, Karpinski E, Wu G, Cantiello HF and Chen XZ. (2005) Alpha-actinin associates with polycystin-2 and regulates its channel activity. Hum. Mol. Genet. 14: 1587-603 [PMID:15843396]

449. Li Q, Shen PY, Wu G and Chen XZ. (2003) Polycystin-2 interacts with troponin I, an angiogenesis inhibitor. Biochemistry 42: 450-7 [PMID:12525172]

450. Li X, Luo Y, Starremans PG, McNamara CA, Pei Y and Zhou J. (2005) Polycystin-1 and polycystin-2 regulate the cell cycle through the helix-loop-helix inhibitor Id2. Nat. Cell Biol. 7: 1202-12 [PMID:16311606]

451. Li Y, Jia YC, Cui K, Li N, Zheng ZY, Wang YZ and Yuan XB. (2005) Essential role of TRPC channels in the guidance of nerve growth cones by brain-derived neurotrophic factor. Nature 434: 894-8 [PMID:15758952]

452. Li Y, Wright JM, Qian F, Germino GG and Guggino WB. (2005) Polycystin 2 interacts with type I inositol 1,4,5-trisphosphate receptor to modulate intracellular Ca2+ signaling. J. Biol. Chem. 280: 41298-306 [PMID:16223735]

453. Li Z, Sergouniotis PI, Michaelides M, Mackay DS, Wright GA, Devery S, Moore AT, Holder GE, Robson AG and Webster AR. (2009) Recessive mutations of the gene TRPM1 abrogate ON bipolar cell function and cause complete congenital stationary night blindness in humans. Am. J. Hum. Genet. 85: 711-9 [PMID:19878917]

454. Liao M, Cao E, Julius D and Cheng Y. (2013) Structure of the TRPV1 ion channel determined by electron cryo-microscopy. Nature 504: 107-12 [PMID:24305160]

455. Liapi A and Wood JN. (2005) Extensive co-localization and heteromultimer formation of the vanilloid receptor-like protein TRPV2 and the capsaicin receptor TRPV1 in the adult rat cerebral cortex. Eur. J. Neurosci. 22: 825-34 [PMID:16115206]

456. Liedtke W, Choe Y, Martí-Renom MA, Bell AM, Denis CS, Sali A, Hudspeth AJ, Friedman JM and Heller S. (2000) Vanilloid receptor-related osmotically activated channel (VR-OAC), a candidate vertebrate osmoreceptor. Cell 103: 525-35 [PMID:11081638]

457. Liedtke WB, Heller S, Latorre R, Vargas G, Orta G and Brauchi S. (2007) Voltage and Temperature Gating of ThermoTRP Channels. Frontiers in Neuroscience [PMID:21204490]

458. Lievremont JP, Bird GS and Putney Jr JW. (2005) Mechanism of inhibition of TRPC cation channels by 2aminoethoxydiphenylborane. Mol. Pharmacol. 68: 758-62 [PMID:15933213]

459. Lievremont JP, Numaga T, Vazquez G, Lemonnier L, Hara Y, Mori E, Trebak M, Moss SE, Bird GS and Mori $Y$ et al.. (2005) The role of canonical transient receptor potential 7 in B-cell receptor-activated channels. J. Biol. Chem. 280: 35346-51 [PMID:16123040] 
460. Liman ER. (2007) TRPM5 and taste transduction. Handb Exp Pharmacol 287-98 [PMID:17217064]

461. Liman ER, Corey DP and Dulac C. (1999) TRP2: a candidate transduction channel for mammalian pheromone sensory signaling. Proc. Natl. Acad. Sci. U.S.A. 96: 5791-6 [PMID:10318963]

462. Liman, E. R. and Dulac and C.. (2007) TRP Ion Channel Function in Sensory Transduction and Cellular Signaling Cascades Frontiers in Neuroscience Edited by W. B. Liedtke and S. Heller:

463. Lin W, Ezekwe Jr EA, Zhao Z, Liman ER and Restrepo D. (2008) TRPM5-expressing microvillous cells in the main olfactory epithelium. BMC Neurosci 9: 114 [PMID:19025635]

464. Lin W, Margolskee R, Donnert G, Hell SW and Restrepo D. (2007) Olfactory neurons expressing transient receptor potential channel M5 (TRPM5) are involved in sensing semiochemicals. Proc. Natl. Acad. Sci. U.S.A. 104: 2471-6 [PMID:17267604]

465. Lin W, Ogura T, Margolskee RF, Finger TE and Restrepo D. (2008) TRPM5-expressing solitary chemosensory cells respond to odorous irritants. J. Neurophysiol. 99: 1451-60 [PMID:18160424]

466. Lin Y and Sun Z. (2012) Antiaging gene Klotho enhances glucose-induced insulin secretion by upregulating plasma membrane levels of TRPV2 in MIN6 $\beta$-cells. Endocrinology 153: 3029-39 [PMID:22597535]

467. Lin Z, Chen Q, Lee M, Cao X, Zhang J, Ma D, Chen L, Hu X, Wang H and Wang Xet al.. (2012) Exome sequencing reveals mutations in TRPV 3 as a cause of Olmsted syndrome. Am. J. Hum. Genet.90: 558-64 [PMID:22405088]

468. Lindvall JM, Blomberg KE, Wennborg A and Smith CI. (2005) Differential expression and molecular characterisation of Lmo7, Myo1e, Sash1, and Mcoln2 genes in Btk-defective B-cells. Cell. Immunol. 235: 46-55 [PMID:16137664]

469. Link TM, Park U, Vonakis BM, Raben DM, Soloski MJ and Caterina MJ. (2010) TRPV2 has a pivotal role in macrophage particle binding and phagocytosis. Nat. Immunol. 11: 232-9 [PMID:20118928]

470. Liu B, Escalera J, Balakrishna S, Fan L, Caceres AI, Robinson E, Sui A, McKay MC, McAlexander MA and Herrick CA et al.. (2013) TRPA1 controls inflammation and pruritogen responses in allergic contact dermatitis. FASEB J. 27: 3549-63 [PMID:23722916]

471. Liu B, Yao J, Zhu MX and Qin F. (2011) Hysteresis of gating underlines sensitization of TRPV3 channels. J. Gen. Physiol. 138: 509-20 [PMID:22006988]

472. Liu D and Liman ER. (2003) Intracellular Ca2+ and the phospholipid PIP2 regulate the taste transduction ion channel TRPM5. Proc. Natl. Acad. Sci. U.S.A. 100: 15160-5 [PMID:14657398]

473. Liu D, Zhang Z and Liman ER. (2005) Extracellular acid block and acid-enhanced inactivation of the Ca2+activated cation channel TRPM5 involve residues in the S3-S4 and S5-S6 extracellular domains. J. Biol. Chem. 280: 20691-9 [PMID:15731110]

474. Liu G, Xie C, Sun F, Xu X, Yang Y, Zhang T, Deng Y, Wang D, Huang Z and Yang let al.. (2010) Clinical significance of transient receptor potential vanilloid 2 expression in human hepatocellular carcinoma. Cancer Genet. Cytogenet. 197: 54-9 [PMID:20113837]

475. Liu H, Chatel S, Simard C, Syam N, Salle L, Probst V, Morel J, Millat G, Lopez M and Abriel Het al.. (2013) Molecular genetics and functional anomalies in a series of 248 Brugada cases with 11 mutations in the TRPM4 channel. PLOS ONE 8: e54131 [PMID:23382873]

476. Liu K, Samuel M, Ho M, Harrison RK and Paslay JW. (2010) NPPB structure-specifically activates TRPA1 channels. Biochem. Pharmacol. 80: 113-21 [PMID:20226176]

477. Liu P, Shah BP, Croasdell S and Gilbertson TA. (2011) Transient receptor potential channel type M5 is essential for fat taste. J. Neurosci. 31: 8634-42 [PMID:21653867]

478. Liu T and Ji RR. (2012) Oxidative stress induces itch via activation of transient receptor potential subtype ankyrin 1 in mice. Neurosci Bull 28: 145-54 [PMID:22466125]

479. Liu W, Su LT, Khadka DK, Mezzacappa C, Komiya Y, Sato A, Habas R and Runnels LW. (2011) TRPM7 regulates gastrulation during vertebrate embryogenesis. Dev. Biol. 350: 348-57 [PMID:21145885]

480. Liu X, Bandyopadhyay BC, Bandyopadhyay B, Nakamoto T, Singh B, Liedtke W, Melvin JE and Ambudkar I. (2006) A role for AQP5 in activation of TRPV4 by hypotonicity: concerted involvement of AQP5 and TRPV4 in regulation of cell volume recovery. J. Biol. Chem. 281: 15485-95 [PMID:16571723] 
481. Liu Y and Qin N. (2011) TRPM8 in health and disease: cold sensing and beyond.Adv. Exp. Med. Biol. 704: 185-208 [PMID:21290296]

482. LopezJimenez ND, Cavenagh MM, Sainz E, Cruz-Ithier MA, Battey JF and Sullivan SL. (2006) Two members of the TRPP family of ion channels, Pkd113 and Pkd2l1, are co-expressed in a subset of taste receptor cells. J. Neurochem. 98: 68-77 [PMID:16805797]

483. Lowin T, Apitz M, Anders $\mathrm{S}$ and Straub RH. (2015) Anti-inflammatory effects of $\mathrm{N}$-acylethanolamines in rheumatoid arthritis synovial cells are mediated by TRPV 1 and TRPA 1 in a COX-2 dependent manner. Arthritis Res. Ther. 17: 321 [PMID:26567045]

484. Lucas $P$, Ukhanov K, Leinders-Zufall T and Zufall F. (2003) A diacylglycerol-gated cation channel in vomeronasal neuron dendrites is impaired in TRPC2 mutant mice: mechanism of pheromone transduction. Neuron 40: 551-61 [PMID:14642279]

485. Luo Y, Vassilev PM, Li X, Kawanabe Y and Zhou J. (2003) Native polycystin 2 functions as a plasma membrane Ca2+-permeable cation channel in renal epithelia. Mol. Cell. Biol. 23: 2600-7 [PMID:12640140]

486. Lussier MP, Cayouette S, Lepage PK, Bernier CL, Francoeur N, St-Hilaire M, Pinard M and Boulay G. (2005) MxA, a member of the dynamin superfamily, interacts with the ankyrin-like repeat domain of TRPC. J. Biol. Chem. 280: 19393-400 [PMID:15757897]

487. Ma S, G G, Ak VE, Jf D and H H. (2008) Menthol derivative WS-12 selectively activates transient receptor potential melastatin-8 (TRPM8) ion channels. Pak J Pharm Sci 21: 370-8 [PMID:18930858]

488. Ma X, Nilius B, Wong JW, Huang $Y$ and Yao X. (2011) Electrophysiological properties of heteromeric TRPV4-C1 channels. Biochim. Biophys. Acta 1808: 2789-97 [PMID:21871867]

489. Ma X, Qiu S, Luo J, Ma Y, Ngai CY, Shen B, Wong CO, Huang Y and Yao X. (2010) Functional role of vanilloid transient receptor potential 4-canonical transient receptor potential 1 complex in flow-induced Ca2+ influx. Arterioscler. Thromb. Vasc. Biol. 30: 851-8 [PMID:20093626]

490. Macpherson LJ, Dubin AE, Evans MJ, Marr F, Schultz PG, Cravatt BF and Patapoutian A. (2007) Noxious compounds activate TRPA1 ion channels through covalent modification of cysteines. Nature 445: 541-5 [PMID:17237762]

491. Macpherson LJ, Geierstanger BH, Viswanath V, Bandell M, Eid SR, Hwang S and Patapoutian A. (2005) The pungency of garlic: activation of TRPA1 and TRPV1 in response to allicin. Curr. Biol. 15: 929-34 [PMID:15916949]

492. Macpherson LJ, Hwang SW, Miyamoto T, Dubin AE, Patapoutian A and Story GM. (2006) More than cool: promiscuous relationships of menthol and other sensory compounds. Mol. Cell. Neurosci. 32: 335-43 [PMID:16829128]

493. Macpherson LJ, Xiao B, Kwan KY, Petrus MJ, Dubin AE, Hwang S, Cravatt B, Corey DP and Patapoutian A. (2007) An ion channel essential for sensing chemical damage. J. Neurosci. 27: 11412-5 [PMID:17942735]

494. Madrid R, Donovan-Rodríguez T, Meseguer V, Acosta MC, Belmonte C and Viana F. (2006) Contribution of TRPM8 channels to cold transduction in primary sensory neurons and peripheral nerve terminals. J. Neurosci. 26: 12512-25 [PMID:17135413]

495. Magnone M, Bauer I, Poggi A, Mannino E, Sturla L, Brini M, Zocchi E, De Flora A, Nencioni A and Bruzzone S. (2012) NAD+ levels control $\mathrm{Ca2}+$ store replenishment and mitogen-induced increase of cytosolic $\mathrm{Ca} 2+$ by Cyclic ADP-ribose-dependent TRPM2 channel gating in human T lymphocytes. J. Biol. Chem. 287: 21067-81 [PMID:22547068]

496. Maher M, Ao H, Banke T, Nasser N, Wu NT, Breitenbucher JG, Chaplan SR and Wickenden AD. (2008) Activation of TRPA1 by farnesyl thiosalicylic acid. Mol. Pharmacol. 73: 1225-34 [PMID:18171730]

497. Mahieu F, Owsianik G, Verbert L, Janssens A, De Smedt H, Nilius B and Voets T. (2007) TRPM8independent menthol-induced $\mathrm{Ca} 2+$ release from endoplasmic reticulum and Golgi. J. Biol. Chem. 282: 3325-36 [PMID:17142461]

498. Majeed Y, Agarwal AK, Naylor J, Seymour VA, Jiang S, Muraki K, Fishwick CW and Beech DJ. (2010) Cisisomerism and other chemical requirements of steroidal agonists and partial agonists acting at TRPM3 channels. Br. J. Pharmacol. 161: 430-41 [PMID:20735426] 
499. Majeed Y, Amer MS, Agarwal AK, McKeown L, Porter KE, O'Regan DJ, Naylor J, Fishwick CW, Muraki K and Beech DJ. (2011) Stereo-selective inhibition of transient receptor potential TRPC5 cation channels by neuroactive steroids. Br. J. Pharmacol. 162: 1509-20 [PMID:21108630]

500. Majeed Y, Bahnasi Y, Seymour VA, Wilson LA, Milligan CJ, Agarwal AK, Sukumar P, Naylor J and Beech DJ. (2011) Rapid and contrasting effects of rosiglitazone on transient receptor potential TRPM3 and TRPC5 channels. Mol. Pharmacol. 79: 1023-30 [PMID:21406603]

501. Majhi RK, Sahoo SS, Yadav M, Pratheek BM, Chattopadhyay S and Goswami C. (2015) Functional expression of TRPV channels in T cells and their implications in immune regulation. FEBS J. 282: 2661-81 [PMID:25903376]

502. Marigo V, Courville K, Hsu WH, Feng JM and Cheng H. (2009) TRPM4 impacts on Ca2+ signals during agonist-induced insulin secretion in pancreatic beta-cells. Mol. Cell. Endocrinol. 299: 194-203 [PMID:19063936]

503. Maroto R, Raso A, Wood TG, Kurosky A, Martinac B and Hamill OP. (2005) TRPC1 forms the stretchactivated cation channel in vertebrate cells. Nat. Cell Biol. 7: 179-85 [PMID:15665854]

504. Martina JA, Lelouvier B and Puertollano R. (2009) The calcium channel mucolipin-3 is a novel regulator of trafficking along the endosomal pathway. Traffic 10: 1143-56 [PMID:19497048]

505. Masuyama R, Vriens J, Voets T, Karashima Y, Owsianik G, Vennekens R, Lieben L, Torrekens S, Moermans $\mathrm{K}$ and Vanden Bosch A et al.. (2008) TRPV4-mediated calcium influx regulates terminal differentiation of osteoclasts. Cell Metab. 8: 257-65 [PMID:18762026]

506. Materazzi S, Nassini R, Andrè E, Campi B, Amadesi S, Trevisani M, Bunnett NW, Patacchini R and Geppetti P. (2008) Cox-dependent fatty acid metabolites cause pain through activation of the irritant receptor TRPA1. Proc. Natl. Acad. Sci. U.S.A. 105: 12045-50 [PMID:18687886]

507. Mathar I, Kecskes M, Van der Mieren G, Jacobs G, Camacho Londoño JE, Uhl S, Flockerzi V, Voets T, Freichel $M$ and Nilius $B$ et al.. (2014) Increased $\beta$-adrenergic inotropy in ventricular myocardium from Trpm4-/- mice. Circ. Res. 114: 283-94 [PMID:24226423]

508. Mathar I, Vennekens R, Meissner M, Kees F, Van der Mieren G, Camacho Londoño JE, Uhl S, Voets T, Hummel $B$ and van den Bergh A et al.. (2010) Increased catecholamine secretion contributes to hypertension in TRPM4-deficient mice. J. Clin. Invest. 120: 3267-79 [PMID:20679729]

509. Matta JA and Ahern GP. (2007) Voltage is a partial activator of rat thermosensitive TRP channels.J. Physiol. (Lond.) 585: 469-82 [PMID:17932142]

510. Matta JA, Cornett PM, Miyares RL, Abe K, Sahibzada N and Ahern GP. (2008) General anesthetics activate a nociceptive ion channel to enhance pain and inflammation. Proc. Natl. Acad. Sci. U.S.A. 105: 8784-9 [PMID:18574153]

511. McCleverty CJ, Koesema E, Patapoutian A, Lesley SA and Kreusch A. (2006) Crystal structure of the human TRPV2 channel ankyrin repeat domain. Protein Sci. 15: 2201-6 [PMID:16882997]

512. McHugh D, Flemming R, Xu SZ, Perraud AL and Beech DJ. (2003) Critical intracellular Ca2+ dependence of transient receptor potential melastatin 2 (TRPM2) cation channel activation. J. Biol. Chem. 278: 11002-6 [PMID:12529379]

513. Mclntyre P, McLatchie LM, Chambers A, Phillips E, Clarke M, Savidge J, Toms C, Peacock M, Shah K and Winter J et al.. (2001) Pharmacological differences between the human and rat vanilloid receptor 1 (VR1).

Br. J. Pharmacol. 132: 1084-94 [PMID:11226139]

514. McKay RR, Szymeczek-Seay CL, Lievremont JP, Bird GS, Zitt C, Jüngling E, Lückhoff $A$ and Putney Jr JW. (2000) Cloning and expression of the human transient receptor potential 4 (TRP4) gene: localization and functional expression of human TRP4 and TRP3. Biochem. J. 351 Pt 3: 735-46 [PMID:11042129]

515. McKemy DD, Neuhausser WM and Julius D. (2002) Identification of a cold receptor reveals a general role for TRP channels in thermosensation. Nature 416: 52-8 [PMID:11882888]

516. McNamara CR, Mandel-Brehm J, Bautista DM, Siemens J, Deranian KL, Zhao M, Hayward NJ, Chong JA, Julius D and Moran MM et al.. (2007) TRPA1 mediates formalin-induced pain. Proc. Natl. Acad. Sci. U.S.A. 104: 13525-30 [PMID:17686976]

517. McNamara FN, Randall A and Gunthorpe MJ. (2005) Effects of piperine, the pungent component of black 
pepper, at the human vanilloid receptor (TRPV1). Br. J. Pharmacol. 144: 781-90 [PMID:15685214]

518. McNulty S and Fonfria E. (2005) The role of TRPM channels in cell death.Pflugers Arch. 451: 235-42 [PMID:16025303]

519. Mei ZZ, Mao HJ and Jiang LH. (2006) Conserved cysteine residues in the pore region are obligatory for human TRPM2 channel function. Am. J. Physiol., Cell Physiol. 291: C1022-8 [PMID:16822940]

520. Melzer N, Hicking G, Göbel K and Wiendl H. (2012) TRPM2 cation channels modulate T cell effector functions and contribute to autoimmune CNS inflammation. PLOS ONE 7: e47617 [PMID:23077651]

521. Mercado J, Gordon-Shaag A, Zagotta WN and Gordon SE. (2010) Ca2+-dependent desensitization of TRPV2 channels is mediated by hydrolysis of phosphatidylinositol 4,5-bisphosphate. J. Neurosci. 30: 13338-47 [PMID:20926660]

522. Meseguer V, Alpizar YA, Luis E, Tajada S, Denlinger B, Fajardo O, Manenschijn JA, Fernández-Peña C, Talavera A and Kichko T et al.. (2014) TRPA1 channels mediate acute neurogenic inflammation and pain produced by bacterial endotoxins. Nat Commun 5: 3125 [PMID:24445575]

523. Meseguer V, Karashima Y, Talavera K, D'Hoedt D, Donovan-Rodríguez T, Viana F, Nilius B and Voets T. (2008) Transient receptor potential channels in sensory neurons are targets of the antimycotic agent clotrimazole. J. Neurosci. 28: 576-86 [PMID:18199759]

524. Miehe S, Bieberstein A, Arnould I, Ihdene O, Rütten H and Strübing C. (2010) The phospholipid-binding protein SESTD1 is a novel regulator of the transient receptor potential channels TRPC4 and TRPC5. J. Biol. Chem. 285: 12426-34 [PMID:20164195]

525. Mihara H, Boudaka A, Shibasaki K, Yamanaka A, Sugiyama T and Tominaga M. (2010) Involvement of TRPV2 activation in intestinal movement through nitric oxide production in mice. J. Neurosci. 30: 16536-44 [PMID:21147993]

526. Mihara H, Suzuki N, Yamawaki H, Tominaga M and Sugiyama T. (2013) TRPV2 ion channels expressed in inhibitory motor neurons of gastric myenteric plexus contribute to gastric adaptive relaxation and gastric emptying in mice. Am. J. Physiol. Gastrointest. Liver Physiol. 304: G235-40 [PMID:23203157]

527. Miller AJ, Du J, Rowan S, Hershey CL, Widlund HR and Fisher DE. (2004) Transcriptional regulation of the melanoma prognostic marker melastatin (TRPM1) by MITF in melanocytes and melanoma. Cancer Res. 64: 509-16 [PMID:14744763]

528. Miller M, Shi J, Zhu Y, Kustov M, Tian JB, Stevens A, Wu M, Xu J, Long S and Yang Pet al.. (2011) Identification of ML204, a novel potent antagonist that selectively modulates native TRPC4/C5 ion channels. J. Biol. Chem. 286: 33436-46 [PMID:21795696]

529. Minard A, Bauer CC, Wright DJ, Rubaiy HN, Muraki K, Beech DJ and Bon RS. (2018) Remarkable Progress with Small-Molecule Modulation of TRPC1/4/5 Channels: Implications for Understanding the Channels in Health and Disease. Cells 7: [PMID:29865154]

530. Mishra SK, Tisel SM, Orestes P, Bhangoo SK and Hoon MA. (2011) TRPV1-lineage neurons are required for thermal sensation. EMBO J. 30: 582-93 [PMID:21139565]

531. Mitrovic S, Nogueira C, Cantero-Recasens G, Kiefer K, Fernández-Fernández JM, Popoff JF, Casano L, Bard FA, Gomez R and Valverde MA et al.. (2013) TRPM5-mediated calcium uptake regulates mucin secretion from human colon goblet cells. Elife 2: e00658 [PMID:23741618]

532. Mittermeier L, Demirkhanyan L, Stadlbauer B, Breit A, Recordati C, Hilgendorff A, Matsushita M, Braun A, Simmons DG and Zakharian E et al.. (2019) TRPM7 is the central gatekeeper of intestinal mineral absorption essential for postnatal survival. Proc. Natl. Acad. Sci. U.S.A. [PMID:30770447]

533. Miura S, Takahashi K, Imagawa T, Uchida K, Saito S, Tominaga M and Ohta T. (2013) Involvement of TRPA1 activation in acute pain induced by cadmium in mice. Mol Pain 9: 7 [PMID:23448290]

534. Miyagi K, Kiyonaka S, Yamada K, Miki T, Mori E, Kato K, Numata T, Sawaguchi Y, Numaga T and Kimura T et al.. (2009) A pathogenic $C$ terminus-truncated polycystin-2 mutant enhances receptor-activated $\mathrm{Ca2+}$ entry via association with TRPC3 and TRPC7. J. Biol. Chem. 284: 34400-12 [PMID:19812035]

535. Mizoguchi F, Mizuno A, Hayata T, Nakashima K, Heller S, Ushida T, Sokabe M, Miyasaka N, Suzuki M and Ezura $Y$ et al.. (2008) Transient receptor potential vanilloid 4 deficiency suppresses unloading-induced bone loss. J. Cell. Physiol. 216: 47-53 [PMID:18264976] 
536. Mizuno N, Kitayama S, Saishin Y, Shimada S, Morita K, Mitsuhata C, Kurihara H and Dohi T. (1999) Molecular cloning and characterization of rat trp homologues from brain. Brain Res. Mol. Brain Res. 64: 4151 [PMID:9889314]

537. Mochizuki T, Wu G, Hayashi T, Xenophontos SL, Veldhuisen B, Saris JJ, Reynolds DM, Cai Y, Gabow PA and Pierides A et al.. (1996) PKD2, a gene for polycystic kidney disease that encodes an integral membrane protein. Science 272: 1339-42 [PMID:8650545]

538. Monet M, Gkika D, Lehen'kyi V, Pourtier A, Vanden Abeele F, Bidaux G, Juvin V, Rassendren F, Humez S and Prevarsakaya N. (2009) Lysophospholipids stimulate prostate cancer cell migration via TRPV2 channel activation. Biochim. Biophys. Acta 1793: 528-39 [PMID:19321128]

539. Monet M, Lehen'kyi V, Gackiere F, Firlej V, Vandenberghe M, Roudbaraki M, Gkika D, Pourtier A, Bidaux $G$ and Slomianny $C$ et al.. (2010) Role of cationic channel TRPV2 in promoting prostate cancer migration and progression to androgen resistance. Cancer Res. 70: 1225-35 [PMID:20103638]

540. Monteilh-Zoller MK, Hermosura MC, Nadler MJ, Scharenberg AM, Penner R and Fleig A. (2003) TRPM7 provides an ion channel mechanism for cellular entry of trace metal ions. J. Gen. Physiol. 121: 49-60 [PMID:12508053]

541. Moqrich A, Hwang SW, Earley TJ, Petrus MJ, Murray AN, Spencer KS, Andahazy M, Story GM and Patapoutian A. (2005) Impaired thermosensation in mice lacking TRPV3, a heat and camphor sensor in the skin. Science 307: 1468-72 [PMID:15746429]

542. Moran MM and Szallasi A. (2018) Targeting nociceptive transient receptor potential channels to treat chronic pain: current state of the field. Br. J. Pharmacol. 175: 2185-2203 [PMID:28924972]

543. Morelli MB, Nabissi M, Amantini C, Farfariello V, Ricci-Vitiani L, di Martino S, Pallini R, Larocca LM, Caprodossi S and Santoni M et al.. (2012) The transient receptor potential vanilloid-2 cation channel impairs glioblastoma stem-like cell proliferation and promotes differentiation. Int. J. Cancer 131: E1067-77 [PMID:22492283]

544. Morgans CW, Zhang J, Jeffrey BG, Nelson SM, Burke NS, Duvoisin RM and Brown RL.. (2009) TRPM1 is required for the depolarizing light response in retinal ON-bipolar cells. Proc Natl Acad Sci U S A 106: 19174-8 [PMID:19861548]

545. Mori Y, Takada N, Okada T, Wakamori M, Imoto K, Wanifuchi H, Oka H, Oba A, Ikenaka K and Kurosaki T. (1998) Differential distribution of TRP Ca2+ channel isoforms in mouse brain. Neuroreport 9: 507-15 [PMID:9512398]

546. Motter AL and Ahern GP. (2012) TRPA1 is a polyunsaturated fatty acid sensor in mammals.PLoS ONE 7: e38439 [PMID:22723860]

547. Moussaieff A, Rimmerman N, Bregman T, Straiker A, Felder CC, Shoham S, Kashman Y, Huang SM, Lee $\mathrm{H}$ and Shohami E et al.. (2008) Incensole acetate, an incense component, elicits psychoactivity by activating TRPV3 channels in the brain. FASEB J. 22: 3024-34 [PMID:18492727]

548. MRC. AZD1386 TRPV1 ion channel inhibitor.

549. Mukhopadhyay I, Gomes P, Aranake S, Shetty M, Karnik P, Damle M, Kuruganti S, Thorat S and Khairatkar-Joshi N. (2011) Expression of functional TRPA1 receptor on human lung fibroblast and epithelial cells. J. Recept. Signal Transduct. Res. 31: 350-8 [PMID:21848366]

550. Murakami M, Ohba T, Xu F, Shida S, Satoh E, Ono K, Miyoshi I, Watanabe H, Ito H and lijima T. (2005) Genomic organization and functional analysis of murine PKD2L1. J. Biol. Chem. 280: 5626-35 [PMID:15548533]

551. Murakami M, Xu F, Miyoshi I, Sato E, Ono K and lijima T. (2003) Identification and characterization of the murine TRPM4 channel. Biochem. Biophys. Res. Commun. 307: 522-8 [PMID:12893253]

552. Muraki K, Iwata Y, Katanosaka Y, Ito T, Ohya S, Shigekawa M and Imaizumi Y. (2003) TRPV2 is a component of osmotically sensitive cation channels in murine aortic myocytes. Circ. Res. 93: 829-38 [PMID:14512441]

553. Murata T, Lin MI, Stan RV, Bauer PM, Yu J and Sessa WC. (2007) Genetic evidence supporting caveolae microdomain regulation of calcium entry in endothelial cells. J. Biol. Chem. 282: 16631-43 [PMID:17416589] 
554. Myers BR, Sigal YM and Julius D. (2009) Evolution of thermal response properties in a cold-activated TRP channel. PLOS ONE 4: e5741 [PMID:19492038]

555. Mälkiä A, Madrid R, Meseguer V, de la Peña E, Valero M, Belmonte C and Viana F. (2007) Bidirectional shifts of TRPM8 channel gating by temperature and chemical agents modulate the cold sensitivity of mammalian thermoreceptors. J. Physiol. (Lond.) 581: 155-74 [PMID:17317754]

556. Mälkiä A, Morenilla-Palao $C$ and Viana F. (2011) The emerging pharmacology of TRPM8 channels: hidden therapeutic potential underneath a cold surface. Curr Pharm Biotechnol 12: 54-67 [PMID:20932258]

557. Müller D, Hoenderop JG, Meij IC, van den Heuvel LP, Knoers NV, den Hollander AI, Eggert P, GarcíaNieto V, Claverie-Martín F and Bindels RJ. (2000) Molecular cloning, tissue distribution, and chromosomal mapping of the human epithelial Ca2+ channel (ECAC1). Genomics 67: 48-53 [PMID:10945469]

558. Na T and Peng JB. (2014) TRPV5: a Ca(2+) channel for the fine-tuning of $\mathrm{Ca}(2+)$ reabsorptionHandb Exp Pharmacol 222: 321-57 [PMID:24756712]

559. Nabissi M, Morelli MB, Amantini C, Farfariello V, Ricci-Vitiani L, Caprodossi S, Arcella A, Santoni M, Giangaspero F and De Maria R et al.. (2010) TRPV2 channel negatively controls glioma cell proliferation and resistance to Fas-induced apoptosis in ERK-dependent manner. Carcinogenesis 31: 794-803 [PMID:20093382]

560. Nabissi M, Morelli MB, Santoni M and Santoni G. (2013) Triggering of the TRPV2 channel by cannabidiol sensitizes glioblastoma cells to cytotoxic chemotherapeutic agents. Carcinogenesis 34: 48-57 [PMID:23079154]

561. Nadler MJ, Hermosura MC, Inabe K, Perraud AL, Zhu Q, Stokes AJ, Kurosaki T, Kinet JP, Penner R and Scharenberg AM et al.. (2001) LTRPC7 is a Mg.ATP-regulated divalent cation channel required for cell viability. Nature 411: 590-5 [PMID:11385574]

562. Nagamine K, Kudoh J, Minoshima S, Kawasaki K, Asakawa S, Ito F and Shimizu N. (1998) Molecular cloning of a novel putative Ca2+ channel protein (TRPC7) highly expressed in brain. Genomics 54: 124-31 [PMID:9806837]

563. Nagasawa M and Kojima I. (2012) Translocation of calcium-permeable TRPV2 channel to the podosome: Its role in the regulation of podosome assembly. Cell Calcium 51: 186-93 [PMID:22226146]

564. Nagasawa M, Nakagawa Y, Tanaka S and Kojima I. (2007) Chemotactic peptide fMetLeuPhe induces translocation of the TRPV2 channel in macrophages. J. Cell. Physiol. 210: 692-702 [PMID:17154364]

565. Nagase T, Kikuno R, Nakayama M, Hirosawa M and Ohara O. (2000) Prediction of the coding sequences of unidentified human genes. XVIII. The complete sequences of 100 new cDNA clones from brain which code for large proteins in vitro. DNA Res. 7: 273-81 [PMID:10997877]

566. Nagata K, Duggan A, Kumar G and García-Añoveros J. (2005) Nociceptor and hair cell transducer properties of TRPA1, a channel for pain and hearing. J. Neurosci. 25: 4052-61 [PMID:15843607]

567. Nagata K, Zheng L, Madathany T, Castiglioni AJ, Bartles JR and García-Añoveros J. (2008) The varitintwaddler (Va) deafness mutation in TRPML3 generates constitutive, inward rectifying currents and causes cell degeneration. Proc. Natl. Acad. Sci. U.S.A. 105: 353-8 [PMID:18162548]

568. Nakamura M, Sanuki R, Yasuma TR, Onishi A, Nishiguchi KM, Koike C, Kadowaki M, Kondo M, Miyake Y and Furukawa T. (2010) TRPM1 mutations are associated with the complete form of congenital stationary night blindness. Mol. Vis. 16: 425-37 [PMID:20300565]

569. Nakashimo Y, Takumida M, Fukuiri T, Anniko M and Hirakawa K. (2010) Expression of transient receptor potential channel vanilloid (TRPV) 1\&\#x2013;4, melastin (TRPM) 5 and 8, and ankyrin (TRPA1) in the normal and methimazole-treated mouse olfactory epithelium. Acta Otolaryngol. 130: 1278-86 [PMID:20586674]

570. Narukawa M, Koizumi K, Iwasaki Y, Kubota K and Watanabe T. (2010) Galangal pungent component, 1'acetoxychavicol acetate, activates TRPA1. Biosci. Biotechnol. Biochem. 74: 1694-6 [PMID:20699565]

571. Nassenstein C, Kwong K, Taylor-Clark T, Kollarik M, Macglashan DM, Braun A and Undem BJ. (2008) Expression and function of the ion channel TRPA 1 in vagal afferent nerves innervating mouse lungs. $J$. Physiol. (Lond.) 586: 1595-604 [PMID:18218683]

572. Nassini R, Gees M, Harrison S, De Siena G, Materazzi S, Moretto N, Failli P, Preti D, Marchetti N and 
Cavazzini A et al.. (2011) Oxaliplatin elicits mechanical and cold allodynia in rodents via TRPA1 receptor stimulation. Pain 152: 1621-31 [PMID:21481532]

573. Nassini R, Materazzi S, Andrè E, Sartiani L, Aldini G, Trevisani M, Carnini C, Massi D, Pedretti P and Carini $\mathrm{M}$ et al.. (2010) Acetaminophen, via its reactive metabolite $\mathrm{N}$-acetyl-p-benzo-quinoneimine and transient receptor potential ankyrin-1 stimulation, causes neurogenic inflammation in the airways and other tissues in rodents. FASEB J. 24: 4904-16 [PMID:20720158]

574. Nassini R, Materazzi S, Vriens J, Prenen J, Benemei S, De Siena G, la Marca G, Andrè E, Preti D and Avonto $C$ et al.. (2012) The 'headache tree' via umbellulone and TRPA1 activates the trigeminovascular system. Brain 135: 376-90 [PMID:22036959]

575. Nassini R, Pedretti P, Moretto N, Fusi C, Carnini C, Facchinetti F, Viscomi AR, Pisano AR, Stokesberry S and Brunmark $C$ et al.. (2012) Transient receptor potential ankyrin 1 channel localized to non-neuronal airway cells promotes non-neurogenic inflammation. PLoS ONE 7: e42454 [PMID:22905134]

576. Nativi C, Gualdani R, Dragoni E, Di Cesare Mannelli L, Sostegni S, Norcini M, Gabrielli G, la Marca G, Richichi B and Francesconi O et al.. (2013) A TRPA1 antagonist reverts oxaliplatin-induced neuropathic pain. Sci Rep 3: 2005 [PMID:23774285]

577. Naziroğlu M and Ozgül C. (2012) Effects of antagonists and heat on TRPM8 channel currents in dorsal root ganglion neuron activated by nociceptive cold stress and menthol. Neurochem. Res. 37: 314-20 [PMID:21964764]

578. Nealen ML, Gold MS, Thut PD and Caterina MJ. (2003) TRPM8 mRNA is expressed in a subset of coldresponsive trigeminal neurons from rat. J. Neurophysiol. 90: 515-20 [PMID:12634279]

579. Nedungadi TP, Dutta M, Bathina CS, Caterina MJ and Cunningham JT. (2012) Expression and distribution of TRPV2 in rat brain. Exp. Neurol. 237: 223-37 [PMID:22750329]

580. Neely GG, Keene AC, Duchek P, Chang EC, Wang QP, Aksoy YA, Rosenzweig M, Costigan M, Woolf CJ and Garrity PA et al.. (2011) TrpA1 regulates thermal nociception in Drosophila.PLoS ONE 6: e24343 [PMID:21909389]

581. Neeper MP, Liu Y, Hutchinson TL, Wang Y, Flores CM and Qin N. (2007) Activation properties of heterologously expressed mammalian TRPV2: evidence for species dependence. J. Biol. Chem. 282: 15894-902 [PMID:17395593]

582. Nelson PL, Zolochevska O, Figueiredo ML, Soliman A, Hsu WH, Feng JM, Zhang H and Cheng H. (2011) Regulation of $\mathrm{Ca}(2+)$-entry in pancreatic $\alpha$-cell line by transient receptor potential melastatin 4 plays a vital role in glucagon release. Mol. Cell. Endocrinol. 335: 126-34 [PMID:21238535]

583. Nie L, Kanzaki M, Shibata H and Kojima I. (1998) Activation of calcium-permeable cation channel by insulin in Chinese hamster ovary cells expressing human insulin receptors. Endocrinology 139: 179-88 [PMID:9421413]

584. Nie L, Oishi Y, Doi I, Shibata H and Kojima I. (1997) Inhibition of proliferation of MCF-7 breast cancer cells by a blocker of $\mathrm{Ca}(2+)$-permeable channel. Cell Calcium 22: 75-82 [PMID:9292225]

585. Niemeyer BA, Bergs C, Wissenbach U, Flockerzi V and Trost C. (2001) Competitive regulation of CaT-likemediated $\mathrm{Ca} 2+$ entry by protein kinase $\mathrm{C}$ and calmodulin. Proc. Natl. Acad. Sci. U.S.A. 98: 3600-5 [PMID:11248124]

586. Niforatos W, Zhang XF, Lake MR, Walter KA, Neelands T, Holzman TF, Scott VE, Faltynek CR, Moreland RB and Chen J. (2007) Activation of TRPA1 channels by the fatty acid amide hydrolase inhibitor 3'carbamoylbiphenyl-3-yl cyclohexylcarbamate (URB597). Mol. Pharmacol. 71: 1209-16 [PMID:17314320]

587. Nijenhuis T, Hoenderop JG, van der Kemp AW and Bindels RJ. (2003) Localization and regulation of the epithelial Ca2+ channel TRPV6 in the kidney. J. Am. Soc. Nephrol. 14: 2731-40 [PMID:14569082]

588. Nilius B. (2007) TRP channels in disease.Biochim. Biophys. Acta 1772: 805-12 [PMID:17368864]

589. Nilius B and Flockerzi V. (2014) Mammalian transient receptor potential (TRP) cation channels. Preface. Handb Exp Pharmacol 223: v - vi [PMID:25296415]

590. Nilius B, Mahieu F, Prenen J, Janssens A, Owsianik G, Vennekens R and Voets T. (2006) The Ca2+activated cation channel TRPM4 is regulated by phosphatidylinositol 4,5-biphosphate. EMBO J. 25: 467-78 [PMID:16424899] 
591. Nilius B and Owsianik G. (2010) Transient receptor potential channelopathies. Pflugers Arch. 460: 437-50 [PMID:20127491]

592. Nilius B, Owsianik G and Voets T. (2008) Transient receptor potential channels meet phosphoinositides. EMBO J. 27: 2809-16 [PMID:18923420]

593. Nilius B, Owsianik G, Voets T and Peters JA. (2007) Transient receptor potential cation channels in disease. Physiol. Rev. 87: 165-217 [PMID:17237345]

594. Nilius B, Prenen J, Droogmans G, Voets T, Vennekens R, Freichel M, Wissenbach U and Flockerzi V. (2003) Voltage dependence of the Ca2+-activated cation channel TRPM4. J. Biol. Chem. 278: 30813-20 [PMID:12799367]

595. Nilius B, Prenen J, Hoenderop JG, Vennekens R, Hoefs S, Weidema AF, Droogmans G and Bindels RJ. (2002) Fast and slow inactivation kinetics of the Ca2+ channels ECaC1 and ECaC2 (TRPV5 and TRPV6). Role of the intracellular loop located between transmembrane segments 2 and 3. J. Biol. Chem. 277: 30852-8 [PMID:12077127]

596. Nilius B, Prenen J, Janssens A, Owsianik G, Wang C, Zhu MX and Voets T. (2005) The selectivity filter of the cation channel TRPM4. J. Biol. Chem. 280: 22899-906 [PMID:15845551]

597. Nilius B, Prenen J, Janssens A, Voets T and Droogmans G. (2004) Decavanadate modulates gating of TRPM4 cation channels. J. Physiol. (Lond.) 560: 753-65 [PMID:15331675]

598. Nilius B, Prenen J, Tang J, Wang C, Owsianik G, Janssens A, Voets T and Zhu MX. (2005) Regulation of the $\mathrm{Ca} 2+$ sensitivity of the nonselective cation channel TRPM4. J. Biol. Chem. 280: 6423-33 [PMID:15590641]

599. Nilius B, Prenen J, Vennekens R, Hoenderop JG, Bindels RJ and Droogmans G. (2001) Pharmacological modulation of monovalent cation currents through the epithelial Ca2+ channel ECaC1. Br. J. Pharmacol. 134: 453-62 [PMID:11588099]

600. Nilius B, Prenen J, Voets T and Droogmans G. (2004) Intracellular nucleotides and polyamines inhibit the Ca2+-activated cation channel TRPM4b. Pflugers Arch. 448: 70-5 [PMID:14758478]

601. Nilius B, Talavera K, Owsianik G, Prenen J, Droogmans G and Voets T. (2005) Gating of TRP channels: a voltage connection? J. Physiol. (Lond.) 567: 35-44 [PMID:15878939]

602. Nilius B and Vennekens R. (2006) From cardiac cation channels to the molecular dissection of the transient receptor potential channel TRPM4. Pflugers Arch. 453: 313-21 [PMID:16680483]

603. Nilius B, Vennekens R, Prenen J, Hoenderop JG, Bindels RJ and Droogmans G. (2000) Whole-cell and single channel monovalent cation currents through the novel rabbit epithelial $\mathrm{Ca} 2+$ channel ECaC. J. Physiol. (Lond.) 527 Pt 2: 239-48 [PMID:10970426]

604. Nilius B, Vriens J, Prenen J, Droogmans G and Voets T. (2004) TRPV4 calcium entry channel: a paradigm for gating diversity. Am. J. Physiol., Cell Physiol. 286: C195-205 [PMID:14707014]

605. Nina DUllich. (2005) PhD Thesis. In TRPM4 and TRPM5: Functional characterisation and comparison of two novel $\mathrm{Ca}^{2+}$-activated cation channels of the TRPM subfamily Faculteit Geneeskunde, Dept. Moleculaire Celbiologie, KU Leuven:

606. Nomura H, Turco AE, Pei Y, Kalaydjieva L, Schiavello T, Weremowicz S, Ji W, Morton CC, Meisler M and Reeders ST et al.. (1998) Identification of PKDL, a novel polycystic kidney disease 2-like gene whose murine homologue is deleted in mice with kidney and retinal defects. J. Biol. Chem. 273: 25967-73 [PMID:9748274]

607. Nozawa K, Kawabata-Shoda E, Doihara H, Kojima R, Okada H, Mochizuki S, Sano Y, Inamura K, Matsushime $\mathrm{H}$ and Koizumi T et al.. (2009) TRPA1 regulates gastrointestinal motility through serotonin release from enterochromaffin cells. Proc. Natl. Acad. Sci. U.S.A. 106: 3408-13 [PMID:19211797]

608. Numazaki M, Tominaga T, Takeuchi K, Murayama N, Toyooka H and Tominaga M. (2003) Structural determinant of TRPV1 desensitization interacts with calmodulin. Proc. Natl. Acad. Sci. U.S.A. 100: 8002-6 [PMID:12808128]

609. Oancea E, Vriens J, Brauchi S, Jun J, Splawski I and Clapham DE. (2009) TRPM1 forms ion channels associated with melanin content in melanocytes. Sci Signal 2: ra21 [PMID:19436059]

610. Oancea E, Wolfe JT and Clapham DE. (2006) Functional TRPM7 channels accumulate at the plasma 
membrane in response to fluid flow. Circ. Res. 98: 245-53 [PMID:16357306]

611. Obata K, Katsura H, Mizushima T, Yamanaka H, Kobayashi K, Dai Y, Fukuoka T, Tokunaga A, Tominaga $M$ and Noguchi K. (2005) TRPA1 induced in sensory neurons contributes to cold hyperalgesia after inflammation and nerve injury. J. Clin. Invest. 115: 2393-401 [PMID:16110328]

612. Obermüller N, Gallagher AR, Cai Y, Gassler N, Gretz N, Somlo S and Witzgall R. (1999) The rat pkd2 protein assumes distinct subcellular distributions in different organs. Am. J. Physiol. 277: F914-25 [PMID:10600939]

613. Oberwinkler J, Lis A, Giehl KM, Flockerzi V and Philipp SE. (2005) Alternative splicing switches the divalent cation selectivity of TRPM3 channels. J. Biol. Chem. 280: 22540-8 [PMID:15824111]

614. Oberwinkler J and Philipp SE. (2014) TRPM3. Handb Exp Pharmacol 222: 427-59 [PMID:24756716]

615. Oberwinkler J and Phillipp SE. (2007) TRPM3. Handb Exp Pharmacol 253-67 [PMID:17217062]

616. Obukhov AG and Nowycky MC. (2005) A cytosolic residue mediates Mg2+ block and regulates inward current amplitude of a transient receptor potential channel. J. Neurosci. 25: 1234-9 [PMID:15689561]

617. Obukhov AG and Nowycky MC. (2008) TRPC5 channels undergo changes in gating properties during the activation-deactivation cycle. J. Cell. Physiol. 216: 162-71 [PMID:18247362]

618. Odell AF, Van Helden DF and Scott JL. (2008) The spectrin cytoskeleton influences the surface expression and activation of human transient receptor potential channel 4 channels. J. Biol. Chem. 283: 4395-407 [PMID:18048348]

619. Ohki G, Miyoshi T, Murata M, Ishibashi K, Imai M and Suzuki M. (2000) A calcium-activated cation current by an alternatively spliced form of Trp3 in the heart. J. Biol. Chem. 275: 39055-60 [PMID:10984475]

620. Oike H, Wakamori M, Mori Y, Nakanishi H, Taguchi R, Misaka T, Matsumoto I and Abe K. (2006) Arachidonic acid can function as a signaling modulator by activating the TRPM5 cation channel in taste receptor cells. Biochim. Biophys. Acta 1761: 1078-84 [PMID:16935556]

621. Okada T, Inoue R, Yamazaki K, Maeda A, Kurosaki T, Yamakuni T, Tanaka I, Shimizu S, Ikenaka K, Imoto $\mathrm{K}$ and Mori Y. (1999) Molecular and functional characterization of a novel mouse transient receptor potential protein homologue TRP7. $\mathrm{Ca}(2+)$-permeable cation channel that is constitutively activated and enhanced by stimulation of $G$ protein-coupled receptor. The Journal of biological chemistry 274: 27359-70 [PMID:10488066]

622. Okada T, Shimizu S, Wakamori M, Maeda A, Kurosaki T, Takada N, Imoto K and Mori Y. (1998) Molecular cloning and functional characterization of a novel receptor-activated TRP Ca2+ channel from mouse brain. J. Biol. Chem. 273: 10279-87 [PMID:9553080]

623. Olah ME, Jackson MF, Li H, Perez Y, Sun HS, Kiyonaka S, Mori Y, Tymianski M and MacDonald JF. (2009) Ca2+-dependent induction of TRPM2 currents in hippocampal neurons. J. Physiol. (Lond.) 587: 965-79 [PMID:19124544]

624. Omura M and Mombaerts P. (2015) Trpc2-expressing sensory neurons in the mouse main olfactory epithelium of type B express the soluble guanylate cyclase Gucy1b2. Mol. Cell. Neurosci. 65: 114-24 [PMID:25701815]

625. Omura M and Mombaerts P. (2014) Trpc2-expressing sensory neurons in the main olfactory epithelium of the mouse. Cell Rep 8: 583-95 [PMID:25001287]

626. Ong HL and Ambudkar IS. (2017) STIM-TRP Pathways and Microdomain Organization: Contribution of TRPC1 in Store-Operated $\mathrm{Ca}^{2+}$ Entry: Impact on $\mathrm{Ca}^{2+}$ Signaling and Cell Function. Adv. Exp. Med. Biol. 993: 159-188 [PMID:28900914]

627. Onohara N, Nishida M, Inoue R, Kobayashi H, Sumimoto H, Sato Y, Mori Y, Nagao T and Kurose $H$. (2006) TRPC3 and TRPC6 are essential for angiotensin II-induced cardiac hypertrophy. EMBO J. 25: 5305-16 [PMID:17082763]

628. Ordaz B, Tang J, Xiao R, Salgado A, Sampieri A, Zhu MX and Vaca L. (2005) Calmodulin and calcium interplay in the modulation of TRPC5 channel activity. Identification of a novel C-terminal domain for calcium/calmodulin-mediated facilitation. J. Biol. Chem. 280: 30788-96 [PMID:15987684]

629. Otsuguro K, Tang J, Tang Y, Xiao R, Freichel M, Tsvilovskyy V, Ito S, Flockerzi V, Zhu MX and Zholos AV. (2008) Isoform-specific inhibition of TRPC4 channel by phosphatidylinositol 4,5-bisphosphate. J. Biol. 
Chem. 283: 10026-36 [PMID:18230622]

630. Owsianik G, Talavera K, Voets T and Nilius B. (2006) Permeation and selectivity of TRP channels Annu. Rev. Physiol. 68: 685-717 [PMID:16460288]

631. Ozhathil LC, Delalande C, Bianchi B, Nemeth G, Kappel S, Thomet U, Ross-Kaschitza D, Simonin C, Rubin M and Gertsch J et al.. (2018) Identification of potent and selective small molecule inhibitors of the cation channel TRPM4. Br. J. Pharmacol. 175: 2504-2519 [PMID:29579323]

632. Parenti A, De Logu F, Geppetti P and Benemei S. (2016) What is the evidence for the role of TRP channels in inflammatory and immune cells? Br. J. Pharmacol. 173: 953-69 [PMID:26603538]

633. Park CK, Xu ZZ, Liu T, Lü N, Serhan CN and Ji RR. (2011) Resolvin D2 is a potent endogenous inhibitor for transient receptor potential subtype V1/A1, inflammatory pain, and spinal cord synaptic plasticity in mice: distinct roles of resolvin D1, D2, and E1. J. Neurosci. 31: 18433-8 [PMID:22171045]

634. Park KS, Pang B, Park SJ, Lee YG, Bae JY, Park S, Kim I and Kim SJ. (2011) Identification and functional characterization of ion channels in CD34(+) hematopoietic stem cells from human peripheral blood. Mol.

Cells 32: 181-8 [PMID:21638203]

635. Park U, Vastani N, Guan Y, Raja SN, Koltzenburg M and Caterina MJ. (2011) TRP vanilloid 2 knock-out mice are susceptible to perinatal lethality but display normal thermal and mechanical nociception. $J$. Neurosci. 31: 11425-36 [PMID:21832173]

636. Parnas M, Peters M, Dadon D, Lev S, Vertkin I, Slutsky I and Minke B. (2009) Carvacrol is a novel inhibitor of Drosophila TRPL and mammalian TRPM7 channels. Cell Calcium 45: 300-9 [PMID:19135721]

637. Patapoutian A and Macpherson L. (2006) Channeling pain. Nat. Med. 12: 506-7 [PMID:16675993]

638. Patel A, Sharif-Naeini R, Folgering JR, Bichet D, Duprat F and Honoré E. (2010) Canonical TRP channels and mechanotransduction: from physiology to disease states. Pflugers Arch. 460: 571-81 [PMID:20490539]

639. Paulsen CE, Armache JP, Gao Y, Cheng Y and Julius D. (2015) Structure of the TRPA1 ion channel suggests regulatory mechanisms. Nature 520: 511-7 [PMID:25855297]

640. Pedersen SF, Owsianik G and Nilius B. (2005) TRP channels: an overview.Cell Calcium 38: 233-52 [PMID:16098585]

641. Pei Y, Wang K, Kasenda M, Paterson AD, Liang Y, Huang E, Lian J, Rogovea E, Somlo S and St GeorgeHyslop P. (1998) A novel frameshift mutation induced by an adenosine insertion in the polycystic kidney disease 2 (PKD2) gene. Kidney Int. 53: 1127-32 [PMID:9573526]

642. Pei Y, Watnick T, He N, Wang K, Liang Y, Parfrey P, Germino G and St George-Hyslop P. (1999) Somatic PKD2 mutations in individual kidney and liver cysts support a "two-hit" model of cystogenesis in type 2 autosomal dominant polycystic kidney disease. J. Am. Soc. Nephrol. 10: 1524-9 [PMID:10405208]

643. Peier AM, Moqrich A, Hergarden AC, Reeve AJ, Andersson DA, Story GM, Earley TJ, Dragoni I, McIntyre $\mathrm{P}$ and Bevan S et al.. (2002) A TRP channel that senses cold stimuli and menthol.Cell 108: 705-15 [PMID:11893340]

644. Peier AM, Reeve AJ, Andersson DA, Mogrich A, Earley TJ, Hergarden AC, Story GM, Colley S, Hogenesch JB and McIntyre P et al.. (2002) A heat-sensitive TRP channel expressed in keratinocytes. Science 296: 2046-9 [PMID:12016205]

645. Pelucchi B, Aguiari G, Pignatelli A, Manzati E, Witzgall R, Del Senno L and Belluzzi O. (2006) Nonspecific cation current associated with native polycystin-2 in HEK-293 cells. J. Am. Soc. Nephrol. 17: 388-97 [PMID:16396967]

646. Peng JB, Brown EM and Hediger MA. (2001) Structural conservation of the genes encoding CaT1, CaT2, and related cation channels. Genomics 76: 99-109 [PMID:11549322]

647. Peng JB, Chen XZ, Berger UV, Vassilev PM, Brown EM and Hediger MA. (2000) A rat kidney-specific calcium transporter in the distal nephron. J. Biol. Chem. 275: 28186-94 [PMID:10875938]

648. Peng JB, Chen XZ, Berger UV, Vassilev PM, Tsukaguchi H, Brown EM and Hediger MA. (1999) Molecular cloning and characterization of a channel-like transporter mediating intestinal calcium absorption. J. Biol. Chem. 274: 22739-46 [PMID:10428857]

649. Peng JB, Chen XZ, Berger UV, Weremowicz S, Morton CC, Vassilev PM, Brown EM and Hediger MA. 
(2000) Human calcium transport protein CaT1. Biochem. Biophys. Res. Commun. 278: 326-32 [PMID:11097838]

650. Peng JB, Zhuang L, Berger UV, Adam RM, Williams BJ, Brown EM, Hediger MA and Freeman MR. (2001) CaT1 expression correlates with tumor grade in prostate cancer. Biochem. Biophys. Res. Commun. 282: 729-34 [PMID:11401523]

651. Pennekamp P, Bogdanova N, Wilda M, Markoff A, Hameister H, Horst J and Dworniczak B. (1998) Characterization of the murine polycystic kidney disease (Pkd2) gene. Mamm. Genome 9: 749-52 [PMID:9716661]

652. Pereira I, Mendes SJ, Pereira DM, Muniz TF, Colares VL, Monteiro CR, Martins MM, Grisotto MA, Monteiro-Neto V and Monteiro SG et al.. (2017) Transient Receptor Potential Ankyrin 1 Channel Expression on Peripheral Blood Leukocytes from Rheumatoid Arthritic Patients and Correlation with Pain and Disability. Front Pharmaco/8: 53 [PMID:28239353]

653. Perraud AL, Fleig A, Dunn CA, Bagley LA, Launay P, Schmitz C, Stokes AJ, Zhu Q, Bessman MJ, Penner $R$, Kinet JP and Scharenberg AM. (2001) ADP-ribose gating of the calcium-permeable LTRPC2 channel revealed by Nudix motif homology. Nature 411: 595-9 [PMID:11385575]

654. Perraud AL, Schmitz C and Scharenberg AM. (2003) TRPM2 Ca2+ permeable cation channels: from gene to biological function. Cell Calcium 33: 519-31 [PMID:12765697]

655. Petrus M, Peier AM, Bandell M, Hwang SW, Huynh T, Olney N, Jegla T and Patapoutian A. (2007) A role of TRPA1 in mechanical hyperalgesia is revealed by pharmacological inhibition. Mol Pain 3: 40 [PMID:18086313]

656. Peyrot des Gachons C, Uchida K, Bryant B, Shima A, Sperry JB, Dankulich-Nagrudny L, Tominaga M, Smith 3rd AB, Beauchamp GK and Breslin PA. (2011) Unusual pungency from extra-virgin olive oil is attributable to restricted spatial expression of the receptor of oleocanthal. J. Neurosci. 31: 999-1009 [PMID:21248124]

657. Phelan KD, Shwe UT, Abramowitz J, Wu H, Rhee SW, Howell MD, Gottschall PE, Freichel M, Flockerzi V and Birnbaumer $L$ et al.. (2013) Canonical transient receptor channel 5 (TRPC5) and TRPC1/4 contribute to seizure and excitotoxicity by distinct cellular mechanisms. Mol. Pharmacol. 83: 429-38 [PMID:23188715]

658. Phelps CB, Wang RR, Choo SS and Gaudet R. (2010) Differential regulation of TRPV1, TRPV3, and TRPV4 sensitivity through a conserved binding site on the ankyrin repeat domain. J. Biol. Chem. 285: 73140 [PMID:19864432]

659. Philipp S, Hambrecht J, Braslavski L, Schroth G, Freichel M, Murakami M, Cavalié A and Flockerzi V. (1998) A novel capacitative calcium entry channel expressed in excitable cells. EMBO J. 17: 4274-82 [PMID:9687496]

660. Pingle SC, Matta JA and Ahern GP. (2007) Capsaicin receptor: TRPV1 a promiscuous TRP channel. Handb Exp Pharmacol 155-71 [PMID:17217056]

661. Plant TD and Schaefer M. (2003) TRPC4 and TRPC5: receptor-operated Ca2+-permeable nonselective cation channels. Cell Calcium 33: 441-50 [PMID:12765689]

662. Plesch E, Chen CC, Butz E, Scotto Rosato A, Krogsaeter EK, Yinan H, Bartel K, Keller M, Robaa D and Teupser D et al.. (2018) Selective agonist of TRPML2 reveals direct role in chemokine release from innate immune cells. Elife 7: [PMID:30479274]

663. Poole DP, Amadesi S, Veldhuis NA, Abogadie FC, Lieu T, Darby W, Liedtke W, Lew MJ, Mclntyre P and Bunnett NW. (2013) Protease-activated receptor 2 (PAR2) protein and transient receptor potential vanilloid 4 (TRPV4) protein coupling is required for sustained inflammatory signaling. J. Biol. Chem. 288: 5790-802 [PMID:23288842]

664. Poole DP, Pelayo JC, Cattaruzza F, Kuo YM, Gai G, Chiu JV, Bron R, Furness JB, Grady EF and Bunnett NW. (2011) Transient receptor potential ankyrin 1 is expressed by inhibitory motoneurons of the mouse intestine. Gastroenterology 141: 565-75, 575.e1-4 [PMID:21689654]

665. Potier M and Trebak M. (2008) New developments in the signaling mechanisms of the store-operated calcium entry pathway. Pflugers Arch. 457: 405-15 [PMID:18536932]

666. Pozsgai G, Bodkin JV, Graepel R, Bevan S, Andersson DA and Brain SD. (2010) Evidence for the 
pathophysiological relevance of TRPA1 receptors in the cardiovascular system in vivo. Cardiovasc. Res. 87: 760-8 [PMID:20442136]

667. Prawitt D, Enklaar T, Klemm G, Gärtner B, Spangenberg C, Winterpacht A, Higgins M, Pelletier J and Zabel B. (2000) Identification and characterization of MTR1, a novel gene with homology to melastatin (MLSN1) and the trp gene family located in the BWS-WT2 critical region on chromosome 11p15.5 and showing allele-specific expression. Hum. Mol. Genet. 9: 203-16 [PMID:10607831]

668. Prawitt D, Monteilh-Zoller MK, Brixel L, Spangenberg C, Zabel B, Fleig A and Penner R. (2003) TRPM5 is a transient $\mathrm{Ca2}+-$ activated cation channel responding to rapid changes in [Ca2+]i. Proc. Natl. Acad. Sci. U.S.A. 100: 15166-71 [PMID:14634208]

669. Prescott ED and Julius D. (2003) A modular PIP2 binding site as a determinant of capsaicin receptor sensitivity. Science 300: 1284-8 [PMID:12764195]

670. Puertollano R and Kiselyov K. (2009) TRPMLs: in sickness and in health.Am. J. Physiol. Renal Physiol. 296: F1245-54 [PMID:19158345]

671. Puram SV, Riccio A, Koirala S, Ikeuchi Y, Kim AH, Corfas G and Bonni A. (2011) A TRPC5-regulated calcium signaling pathway controls dendrite patterning in the mammalian brain. Genes Dev. 25: 2659-73 [PMID:22135323]

672. Purhonen AK, Louhivuori LM, Kiehne K, Kerman KE and Herzig KH. (2008) TRPA1 channel activation induces cholecystokinin release via extracellular calcium. FEBS Lett. 582: 229-32 [PMID:18082143]

673. Putney JW. (2005) Physiological mechanisms of TRPC activation. Pflugers Arch. 451: 29-34 [PMID:16133266]

674. Pérez CA, Huang L, Rong M, Kozak JA, Preuss AK, Zhang H, Max M and Margolskee RF. (2002) A transient receptor potential channel expressed in taste receptor cells. Nat. Neurosci. 5: 1169-76 [PMID:12368808]

675. Qian F, Germino FJ, Cai Y, Zhang X, Somlo S and Germino GG. (1997) PKD1 interacts with PKD2 through a probable coiled-coil domain. Nat. Genet. 16: 179-83 [PMID:9171830]

676. Qian F and Noben-Trauth K. (2005) Cellular and molecular function of mucolipins (TRPML) and polycystin 2 (TRPP2). Pflugers Arch. 451: 277-85 [PMID:15971078]

677. Qian Q, Hunter LW, Li M, Marin-Padilla M, Prakash YS, Somlo S, Harris PC, Torres VE and Sieck GC. (2003) Pkd2 haploinsufficiency alters intracellular calcium regulation in vascular smooth muscle cells. Hum. Mol. Genet. 12: 1875-80 [PMID:12874107]

678. Qin N, Neeper MP, Liu Y, Hutchinson TL, Lubin ML and Flores CM. (2008) TRPV2 is activated by cannabidiol and mediates CGRP release in cultured rat dorsal root ganglion neurons. J. Neurosci. 28: 6231-8 [PMID:18550765]

679. Qin X, Yue Z, Sun B, Yang W, Xie J, Ni E, Feng Y, Mahmood R, Zhang Y and Yue L. (2013) Sphingosine and FTY720 are potent inhibitors of the transient receptor potential melastatin 7 (TRPM7) channels. British Journal of Pharmacology 168: 1294-1312 [PMID:23145923]

680. Raemdonck K, de Alba J, Birrell MA, Grace M, Maher SA, Irvin CG, Fozard JR, O'Byrne PM and Belvisi MG. (2012) A role for sensory nerves in the late asthmatic response. Thorax 67: 19-25 [PMID:21841185]

681. Reid G. (2005) ThermoTRP channels and cold sensing: what are they really up to?Pflugers Arch. 451: 250-63 [PMID:16075243]

682. Reiser J, Polu KR, Möller CC, Kenlan P, Altintas MM, Wei C, Faul C, Herbert S, Villegas I and AvilaCasado $C$ et al.. (2005) TRPC6 is a glomerular slit diaphragm-associated channel required for normal renal function. Nat. Genet. 37: 739-44 [PMID:15924139]

683. Reynolds DM, Hayashi T, Cai Y, Veldhuisen B, Watnick TJ, Lens XM, Mochizuki T, Qian F, Maeda Y and Li L et al.. (1999) Aberrant splicing in the PKD2 gene as a cause of polycystic kidney disease J. Am. Soc. Nephrol. 10: 2342-51 [PMID:10541293]

684. Riccio A, Li Y, Moon J, Kim KS, Smith KS, Rudolph U, Gapon S, Yao GL, Tsvetkov E and Rodig SJet al.. (2009) Essential role for TRPC5 in amygdala function and fear-related behavior. Cell 137: 761-72 [PMID:19450521]

685. Riccio A, Mattei C, Kelsell RE, Medhurst AD, Calver AR, Randall AD, Davis JB, Benham CD and Pangalos 
MN. (2002) Cloning and functional expression of human short TRP7, a candidate protein for storeoperated Ca2+ influx. J. Biol. Chem. 277: 12302-9 [PMID:11805119]

686. Riccio A, Medhurst AD, Mattei C, Kelsell RE, Calver AR, Randall AD, Benham CD and Pangalos MN. (2002) mRNA distribution analysis of human TRPC family in CNS and peripheral tissues. Brain Res. Mol. Brain Res. 109: 95-104 [PMID:12531519]

687. Rock MJ, Prenen J, Funari VA, Funari TL, Merriman B, Nelson SF, Lachman RS, Wilcox WR, Reyno S and Quadrelli R et al.. (2008) Gain-of-function mutations in TRPV4 cause autosomal dominant brachyolmia. Nat. Genet. 40: 999-1003 [PMID:18587396]

688. Roedding AS, Gao AF, Au-Yeung W, Scarcelli T, Li PP and Warsh JJ. (2012) Effect of oxidative stress on TRPM2 and TRPC3 channels in B lymphoblast cells in bipolar disorder. Bipolar Disord 14: 151-61 [PMID:22420591]

689. Rohacs T. (2009) Phosphoinositide regulation of non-canonical transient receptor potential channels.Cell Calcium 45: 554-65 [PMID:19376575]

690. Rohács T, Lopes CM, Michailidis I and Logothetis DE. (2005) PI(4,5)P2 regulates the activation and desensitization of TRPM8 channels through the TRP domain. Nat. Neurosci. 8: 626-34 [PMID:15852009]

691. Rosker C, Graziani A, Lukas M, Eder P, Zhu MX, Romanin C and Groschner K. (2004) $\mathrm{Ca}(2+)$ signaling by TRPC3 involves $\mathrm{Na}(+)$ entry and local coupling to the $\mathrm{Na}(+) / \mathrm{Ca}(2+)$ exchanger. J. Biol. Chem. 279: 13696704 [PMID:14736881]

692. Rubaiy HN. (2019) Treasure troves of pharmacological tools to study transient receptor potential canonical 1/4/5 channels. Br. J. Pharmacol. 176: 832-846 [PMID:30656647]

693. Rundle DR, Gorbsky G and Tsiokas L. (2004) PKD2 interacts and co-localizes with mDia1 to mitotic spindles of dividing cells: role of mDia1 IN PKD2 localization to mitotic spindles. J. Biol. Chem. 279: 29728-39 [PMID:15123714]

694. Runnels LW, Yue L and Clapham DE. (2001) TRP-PLIK, a bifunctional protein with kinase and ion channel activities. Science 291: 1043-7 [PMID:11161216]

695. Runnels LW, Yue L and Clapham DE. (2002) The TRPM7 channel is inactivated by PIP(2) hydrolysis Nat. Cell Biol. 4: 329-36 [PMID:11941371]

696. Rutter AR, Ma QP, Leveridge M and Bonnert TP. (2005) Heteromerization and colocalization of TrpV1 and TrpV2 in mammalian cell lines and rat dorsal root ganglia. Neuroreport 16: 1735-9 [PMID:16237318]

697. Ryckmans T, Aubdool AA, Bodkin JV, Cox P, Brain SD, Dupont T, Fairman E, Hashizume Y, Ishii N and Kato T et al.. (2011) Design and pharmacological evaluation of PF-4840154, a non-electrophilic reference agonist of the TrpA1 channel. Bioorg. Med. Chem. Lett. 21: 4857-9 [PMID:21741838]

698. Ryskamp DA, Witkovsky P, Barabas P, Huang W, Koehler C, Akimov NP, Lee SH, Chauhan S, Xing W and Rentería RC et al.. (2011) The polymodal ion channel transient receptor potential vanilloid 4 modulates calcium flux, spiking rate, and apoptosis of mouse retinal ganglion cells. J. Neurosci. 31: 7089101 [PMID:21562271]

699. Sabourin J, Lamiche C, Vandebrouck A, Magaud C, Rivet J, Cognard C, Bourmeyster N and Constantin B. (2009) Regulation of TRPC1 and TRPC4 cation channels requires an alpha1-syntrophin-dependent complex in skeletal mouse myotubes. J. Biol. Chem. 284: 36248-61 [PMID:19812031]

700. Sah R, Mesirca P, Mason X, Gibson W, Bates-Withers C, Van den Boogert M, Chaudhuri D, Pu WT, Mangoni ME and Clapham DE.. (2013) Timing of myocardial trpm7 deletion during cardiogenesis variably disrupts adult ventricular function, conduction, and repolarization. Circulation 128: 101-114 [PMID:23734001]

701. Sah R, Mesirca P, Van den Boogert M, Rosen J, Mably J, Mangoni ME and Clapham DE.. (2013) Ion channel-kinase TRPM7 is required for maintaining cardiac automaticity. Proceedings of the National Academy of Sciences of the United States of America 110: E3037-3046 [PMID:23878236]

702. Sala-Rabanal M, Wang S and Nichols CG. (2012) On potential interactions between non-selective cation channel TRPM4 and sulfonylurea receptor SUR1. J. Biol. Chem. 287: 8746-56 [PMID:22291026]

703. Salido GM, Sage SO and Rosado JA. (2009) TRPC channels and store-operated $\mathrm{Ca}(2+)$ entry Biochim. Biophys. Acta 1793: 223-30 [PMID:19061922] 
704. Samie M, Wang X, Zhang X, Goschka A, Li X, Cheng X, Gregg E, Azar M, Zhuo Y and Garrity A@et al.. (2013) A TRP channel in the lysosome regulates large particle phagocytosis via focal exocytosis. Dev. Cell 26: 511-24 [PMID:23993788]

705. Samie MA, Grimm C, Evans JA, Curcio-Morelli C, Heller S, Slaugenhaupt SA and Cuajungco MP. (2009) The tissue-specific expression of TRPML2 (MCOLN-2) gene is influenced by the presence of TRPML1. Pflugers Arch. 459: 79-91 [PMID:19763610]

706. Samivel R, Kim DW, Son HR, Rhee YH, Kim EH, Kim JH, Bae JS, Chung YJ, Chung PS and Raz Eet al.. (2016) The role of TRPV1 in the CD4+ T cell-mediated inflammatory response of allergic rhinitis. Oncotarget 7: 148-60 [PMID:26700618]

707. Sano Y, Inamura K, Miyake A, Mochizuki S, Yokoi H, Matsushime H and Furuichi K. (2001) Immunocyte Ca2+ influx system mediated by LTRPC2. Science 293: 1327-30 [PMID:11509734]

708. Satoh S, Tanaka H, Ueda Y, Oyama J, Sugano M, Sumimoto H, Mori Y and Makino N. (2007) Transient receptor potential (TRP) protein 7 acts as a $\mathrm{G}$ protein-activated $\mathrm{Ca2}+$ channel mediating angiotensin IIinduced myocardial apoptosis. Mol. Cell. Biochem. 294: 205-15 [PMID:16838106]

709. Saunders $\mathrm{Cl}$, Kunde DA, Crawford A and Geraghty DP. (2007) Expression of transient receptor potential vanilloid 1 (TRPV1) and 2 (TRPV2) in human peripheral blood. Mol. Immunol. 44: 1429-35 [PMID:16777226]

710. Sawada Y, Hosokawa H, Matsumura K and Kobayashi S. (2008) Activation of transient receptor potential ankyrin 1 by hydrogen peroxide. Eur. J. Neurosci. 27: 1131-42 [PMID:18364033]

711. Schaefer M, Plant TD, Obukhov AG, Hofmann T, Gudermann T and Schultz G. (2000) Receptor-mediated regulation of the nonselective cation channels TRPC4 and TRPC5. J. Biol. Chem. 275: 17517-26 [PMID:10837492]

712. Schappe MS, Szteyn K, Stremska ME, Mendu SK, Downs TK, Seegren PV, Mahoney MA, Dixit S, Krupa JK and Stipes EJ et al.. (2018) Chanzyme TRPM7 Mediates the Ca' Influx Essential for Lipopolysaccharide-Induced Toll-Like Receptor 4 Endocytosis and Macrophage Activation. Immunity 48 : 59-74.e5 [PMID:29343440]

713. Scharenberg AM. (2005) TRPM2 and TRPM7: channel/enzyme fusions to generate novel intracellular sensors. Pflugers Arch. 451: 220-7 [PMID:16001276]

714. Schattling B, Steinbach K, Thies E, Kruse M, Menigoz A, Ufer F, Flockerzi V, Brück W, Pongs $O$ and Vennekens $R$ et al.. (2012) TRPM4 cation channel mediates axonal and neuronal degeneration in experimental autoimmune encephalomyelitis and multiple sclerosis. Nat. Med. 18: 1805-11 [PMID:23160238]

715. Schiller Y. (2004) Activation of a calcium-activated cation current during epileptiform discharges and its possible role in sustaining seizure-like events in neocortical slices. J. Neurophysiol. 92: 862-72 [PMID:15277598]

716. Schindl R, Fritsch R, Jardin I, Frischauf I, Kahr H, Muik M, Riedl MC, Groschner K and Romanin C. (2012) Canonical transient receptor potential (TRPC) 1 acts as a negative regulator for vanilloid TRPV6-mediated Ca2+ influx. J. Biol. Chem. 287: 35612-20 [PMID:22932896]

717. Schlingmann KP, Weber S, Peters M, Niemann Nejsum L, Vitzthum H, Klingel K, Kratz M, Haddad E, Ristoff $E$ and Dinour $D$ et al.. (2002) Hypomagnesemia with secondary hypocalcemia is caused by mutations in TRPM6, a new member of the TRPM gene family. Nat. Genet. 31: 166-70 [PMID:12032568]

718. Schmiege P, Fine M, Blobel G and Li X. (2017) Human TRPML1 channel structures in open and closed conformations. Nature 550: 366-370 [PMID:29019983]

719. Schmitz C, Dorovkov MV, Zhao X, Davenport BJ, Ryazanov AG and Perraud AL. (2005) The channel kinases TRPM6 and TRPM7 are functionally nonredundant. J. Biol. Chem. 280: 37763-71 [PMID:16150690]

720. Schoeber JP, Topala CN, Lee KP, Lambers TT, Ricard G, van der Kemp AW, Huynen MA, Hoenderop JG and Bindels RJ. (2008) Identification of Nipsnap1 as a novel auxiliary protein inhibiting TRPV6 activity. Pflugers Arch. 457: 91-101 [PMID:18392847]

721. Schulze A, Oehler B, Urban N, Schaefer M and Hill K. (2013) Apomorphine is a bimodal modulator of 
TRPA1 channels. Mol. Pharmacol. 83: 542-51 [PMID:23220749]

722. Schumacher MA and Eilers H. (2010) TRPV1 splice variants: structure and function.Front. Biosci. 15: 87282 [PMID:20515731]

723. Schwartz ES, Christianson JA, Chen X, La JH, Davis BM, Albers KM and Gebhart GF. (2011) Synergistic role of TRPV1 and TRPA1 in pancreatic pain and inflammation. Gastroenterology 140: 1283-1291.e1-2 [PMID:21185837]

724. Schwartz FW. (1987) [Medical orientation data--a challenge to public health].Offent/ Gesundheitswes 49: 229-33 [PMID:2955270]

725. Sel S, Rost BR, Yildirim AO, Sel B, Kalwa H, Fehrenbach H, Renz H, Gudermann T and Dietrich A. (2008) Loss of classical transient receptor potential 6 channel reduces allergic airway response. Clin. Exp. Allergy 38: 1548-58 [PMID:18631347]

726. Semtner M, Schaefer M, Pinkenburg O and Plant TD. (2007) Potentiation of TRPC5 by protonsJ. Biol. Chem. 282: 33868-78 [PMID:17884814]

727. Serafini N, Dahdah A, Barbet G, Demion M, Attout T, Gautier G, Arcos-Fajardo M, Souchet H, Jouvin MH and Vrtovsnik $\mathrm{F}$ et al.. (2012) The TRPM4 channel controls monocyte and macrophage, but not neutrophil, function for survival in sepsis. J. Immunol. 189: 3689-99 [PMID:22933633]

728. Shen D, Wang X, Li X, Zhang X, Yao Z, Dibble S, Dong XP, Yu T, Lieberman AP and Showalter Hळt al.. (2012) Lipid storage disorders block lysosomal trafficking by inhibiting a TRP channel and lysosomal calcium release. Nat Commun 3: 731 [PMID:22415822]

729. Sherkheli MA, Vogt-Eisele AK, Bura D, Beltrán Márques LR, Gisselmann G and Hatt H. (2010) Characterization of selective TRPM8 ligands and their structure activity response (S.A.R) relationship. $J$ Pharm Pharm Sci 13: 242-53 [PMID:20816009]

730. Shi J, Mori E, Mori Y, Mori M, Li J, Ito Y and Inoue R. (2004) Multiple regulation by calcium of murine homologues of transient receptor potential proteins TRPC6 and TRPC7 expressed in HEK293 cells. J. Physiol. (Lond.) 561: 415-32 [PMID:15579537]

731. Shiba T, Maruyama T, Kurohane K, Iwasaki Y, Watanabe T and Imai Y. (2009) TRPA1 and TRPV1 activation is a novel adjuvant effect mechanism in contact hypersensitivity. J. Neuroimmunol. 207: 66-74 [PMID:19135264]

732. Shibasaki K, Murayama N, Ono K, Ishizaki Y and Tominaga M. (2010) TRPV2 enhances axon outgrowth through its activation by membrane stretch in developing sensory and motor neurons. J. Neurosci. 30: 4601-12 [PMID:20357111]

733. Shimizu T, Janssens A, Voets T and Nilius B. (2009) Regulation of the murine TRPP3 channel by voltage, $\mathrm{pH}$, and changes in cell volume. Pflugers Arch. 457: 795-807 [PMID:18663466]

734. Shimizu T, Owsianik G, Freichel M, Flockerzi V, Nilius B and Vennekens R. (2009) TRPM4 regulates migration of mast cells in mice. Cell Calcium 45: 226-32 [PMID:19046767]

735. Shimosato G, Amaya F, Ueda M, Tanaka Y, Decosterd I and Tanaka M. (2005) Peripheral inflammation induces up-regulation of TRPV2 expression in rat DRG. Pain 119: 225-32 [PMID:16298071]

736. Sidhaye VK, Güler AD, Schweitzer KS, D'Alessio F, Caterina MJ and King LS. (2006) Transient receptor potential vanilloid 4 regulates aquaporin- 5 abundance under hypotonic conditions. Proc. Natl. Acad. Sci. U.S.A. 103: 4747-52 [PMID:16537379]

737. Siemens J, Zhou S, Piskorowski R, Nikai T, Lumpkin EA, Basbaum AI, King D and Julius D. (2006) Spider toxins activate the capsaicin receptor to produce inflammatory pain. Nature 444: 208-12 [PMID:17093448]

738. Simard JM, Chen M, Tarasov KV, Bhatta S, Ivanova S, Melnitchenko L, Tsymbalyuk N, West GA and Gerzanich V. (2006) Newly expressed SUR1-regulated NC(Ca-ATP) channel mediates cerebral edema after ischemic stroke. Nat. Med. 12: 433-40 [PMID:16550187]

739. Singh BB, Liu X, Tang J, Zhu MX and Ambudkar IS. (2002) Calmodulin regulates $\mathrm{Ca}(2+)$-dependent feedback inhibition of store-operated $\mathrm{Ca}(2+)$ influx by interaction with a site in the $\mathrm{C}$ terminus of $\mathrm{TrpC} 1$. Mol. Cell 9: 739-50 [PMID:11983166]

740. Sinkins WG, Goel M, Estacion M and Schilling WP. (2004) Association of immunophilins with mammalian TRPC channels. J. Biol. Chem. 279: 34521-9 [PMID:15199065] 
741. Sisignano M, Park CK, Angioni C, Zhang DD, von Hehn C, Cobos EJ, Ghasemlou N, Xu ZZ, Kumaran V and Lu R et al.. (2012) 5,6-EET is released upon neuronal activity and induces mechanical pain hypersensitivity via TRPA1 on central afferent terminals. J. Neurosci. 32: 6364-72 [PMID:22553041]

742. Slaugenhaupt SA. (2002) The molecular basis of mucolipidosis type IV.Curr. Mol. Med. 2: 445-50 [PMID:12125810]

743. Smart D, Gunthorpe MJ, Jerman JC, Nasir S, Gray J, Muir Al, Chambers JK, Randall AD and Davis JB. (2000) The endogenous lipid anandamide is a full agonist at the human vanilloid receptor (hVR1). Br. J. Pharmacol. 129: 227-30 [PMID:10694225]

744. Smart D, Jerman JC, Gunthorpe MJ, Brough SJ, Ranson J, Cairns W, Hayes PD, Randall AD and Davis JB. (2001) Characterisation using FLIPR of human vanilloid VR1 receptor pharmacology. Eur. J. Pharmacol. 417: 51-8 [PMID:11301059]

745. Smith GD, Gunthorpe MJ, Kelsell RE, Hayes PD, Reilly P, Facer P, Wright JE, Jerman JC, Walhin JP and Ooi $L$ et al.. (2002) TRPV3 is a temperature-sensitive vanilloid receptor-like protein.Nature 418: 186-90 [PMID:12077606]

746. Smith MA, Herson PS, Lee K, Pinnock RD and Ashford ML. (2003) Hydrogen-peroxide-induced toxicity of rat striatal neurones involves activation of a non-selective cation channel. J. Physiol. (Lond.) 547: 417-25 [PMID:12562896]

747. Smith PL, Maloney KN, Pothen RG, Clardy J and Clapham DE. (2006) Bisandrographolide from Andrographis paniculata activates TRPV4 channels. J. Biol. Chem. 281: 29897-904 [PMID:16899456]

748. Soboloff J, Spassova M, Xu W, He LP, Cuesta N and Gill DL. (2005) Role of endogenous TRPC6 channels in Ca2+ signal generation in A7r5 smooth muscle cells. J. Biol. Chem. 280: 39786-94 [PMID:16204251]

749. Sokabe T, Fukumi-Tominaga T, Yonemura S, Mizuno A and Tominaga M. (2010) The TRPV4 channel contributes to intercellular junction formation in keratinocytes. J. Biol. Chem. 285: 18749-58 [PMID:20413591]

750. Song X, Zhao Y, Narcisse L, Duffy H, Kress Y, Lee S and Brosnan CF. (2005) Canonical transient receptor potential channel 4 (TRPC4) co-localizes with the scaffolding protein ZO-1 in human fetal astrocytes in culture. Glia 49: 418-29 [PMID:15540229]

751. Spehr J, Hagendorf S, Weiss J, Spehr M, Leinders-Zufall T and Zufall F. (2009) Ca2+-calmodulin feedback mediates sensory adaptation and inhibits pheromone-sensitive ion channels in the vomeronasal organ. J. Neurosci. 29: 2125-35 [PMID:19228965]

752. Staaf S, Oerther S, Lucas G, Mattsson JP and Ernfors P. (2009) Differential regulation of TRP channels in a rat model of neuropathic pain. Pain 144: 187-99 [PMID:19446956]

753. Stallmeyer B, Zumhagen S, Denjoy I, Duthoit G, Hébert JL, Ferrer X, Maugenre S, Schmitz W, Kirchhefer $\mathrm{U}$ and Schulze-Bahr E et al.. (2012) Mutational spectrum in the $\mathrm{Ca}(2+)$--activated cation channel gene TRPM4 in patients with cardiac conductance disturbances. Hum. Mutat. 33: 109-17 [PMID:21887725]

754. Stamboulian S, Moutin MJ, Treves S, Pochon N, Grunwald D, Zorzato F, De Waard M, Ronjat M and Arnoult C. (2005) Junctate, an inositol 1,4,5-triphosphate receptor associated protein, is present in rodent sperm and binds TRPC2 and TRPC5 but not TRPC1 channels. Dev. Biol. 286: 326-37 [PMID:16153633]

755. Starkus JG, Fleig A and Penner R. (2010) The calcium-permeable non-selective cation channel TRPM2 is modulated by cellular acidification. J. Physiol. (Lond.) 588: 1227-40 [PMID:20194125]

756. Starowicz K, Nigam S and Di Marzo V. (2007) Biochemistry and pharmacology of endovanilloids. Pharmacol. Ther. 114: 13-33 [PMID:17349697]

757. Stein AT, Ufret-Vincenty CA, Hua L, Santana LF and Gordon SE. (2006) Phosphoinositide 3-kinase binds to TRPV1 and mediates NGF-stimulated TRPV1 trafficking to the plasma membrane. J. Gen. Physiol. 128: 509-22 [PMID:17074976]

758. Stein RJ, Santos S, Nagatomi J, Hayashi Y, Minnery BS, Xavier M, Patel AS, Nelson JB, Futrell WJ and Yoshimura N et al.. (2004) Cool (TRPM8) and hot (TRPV1) receptors in the bladder and male genital tract. J. Urol. 172: 1175-8 [PMID:15311065]

759. Stiber JA, Tang Y, Li T and Rosenberg PB. (2012) Cytoskeletal regulation of TRPC channels in the 
cardiorenal system. Curr. Hypertens. Rep. 14: 492-7 [PMID:23054893]

760. Stokes A, Wakano C, Koblan-Huberson M, Adra CN, Fleig A and Turner H. (2006) TRPA1 is a substrate for de-ubiquitination by the tumor suppressor CYLD. Cell. Signal. 18: 1584-94 [PMID:16500080]

761. Stokes AJ, Shimoda LM, Koblan-Huberson M, Adra CN and Turner H. (2004) A TRPV2-PKA signaling module for transduction of physical stimuli in mast cells. J. Exp. Med. 200: 137-47 [PMID:15249591]

762. Stokes AJ, Wakano C, Del Carmen KA, Koblan-Huberson M and Turner H. (2005) Formation of a physiological complex between TRPV2 and RGA protein promotes cell surface expression of TRPV2. J. Cell. Biochem. 94: 669-83 [PMID:15547947]

763. Story GM, Peier AM, Reeve AJ, Eid SR, Mosbacher J, Hricik TR, Earley TJ, Hergarden AC, Andersson DA and Hwang SW et al.. (2003) ANKTM1, a TRP-like channel expressed in nociceptive neurons, is activated by cold temperatures. Cell 112: 819-29 [PMID:12654248]

764. Stotz SC, Vriens J, Martyn D, Clardy J and Clapham DE. (2008) Citral sensing by Transient [corrected] receptor potential channels in dorsal root ganglion neurons. PLoS ONE 3: e2082 [PMID:18461159]

765. Stowers L, Holy TE, Meister M, Dulac C and Koentges G. (2002) Loss of sex discrimination and male-male aggression in mice deficient for TRP2. Science 295: 1493-500 [PMID:11823606]

766. Straub RH. (2014) TRPV1, TRPA1, and TRPM8 channels in inflammation, energy redirection, and water retention: role in chronic inflammatory diseases with an evolutionary perspective. J. Mol. Med. 92: 925-37 [PMID:24871046]

767. Streng T, Axelsson HE, Hedlund P, Andersson DA, Jordt SE, Bevan S, Andersson KE, Högestätt ED and Zygmunt PM. (2008) Distribution and function of the hydrogen sulfide-sensitive TRPA1 ion channel in rat urinary bladder. Eur. Urol. 53: 391-9 [PMID:18031925]

768. Stroh O, Freichel M, Kretz O, Birnbaumer L, Hartmann J and Egger V. (2012) NMDA receptor-dependent synaptic activation of TRPC channels in olfactory bulb granule cells. J. Neurosci. 32: 5737-46 [PMID:22539836]

769. Strotmann R, Harteneck C, Nunnenmacher K, Schultz G and Plant TD. (2000) OTRPC4, a nonselective cation channel that confers sensitivity to extracellular osmolarity. Nat. Cell Biol. 2: 695-702 [PMID:11025659]

770. Strotmann R, Schultz G and Plant TD. (2003) Ca2+-dependent potentiation of the nonselective cation channel TRPV4 is mediated by a C-terminal calmodulin binding site. J. Biol. Chem. 278: 26541-9 [PMID:12724311]

771. Strübing C, Krapivinsky G, Krapivinsky L and Clapham DE. (2003) Formation of novel TRPC channels by complex subunit interactions in embryonic brain. J. Biol. Chem. 278: 39014-9 [PMID:12857742]

772. Strübing C, Krapivinsky G, Krapivinsky L and Clapham DE. (2001) TRPC1 and TRPC5 form a novel cation channel in mammalian brain. Neuron 29: 645-55 [PMID:11301024]

773. Su LT, Agapito MA, Li M, Simonson WT, Huttenlocher A, Habas R, Yue L and Runnels LW. (2006) TRPM7 regulates cell adhesion by controlling the calcium-dependent protease calpain. J. Biol. Chem. 281: 11260-70 [PMID:16436382]

774. Su LT, Liu W, Chen HC, González-Pagán O, Habas R and Runnels LW. (2011) TRPM7 regulates polarized cell movements. Biochem. J. 434: 513-21 [PMID:21208190]

775. Su Q, Hu F, Ge X, Lei J, Yu S, Wang T, Zhou Q, Mei C and Shi Y. (2018) Structure of the human PKD1PKD2 complex. Science 361: [PMID:30093605]

776. Sugiura T, Bielefeldt K and Gebhart GF. (2007) Mouse colon sensory neurons detect extracellular acidosis via TRPV1. Am. J. Physiol., Cell Physiol. 292: C1768-74 [PMID:17251322]

777. Sulk M, Seeliger S, Aubert J, Schwab VD, Cevikbas F, Rivier M, Nowak P, Voegel JJ, Buddenkotte J and Steinhoff M. (2012) Distribution and expression of non-neuronal transient receptor potential (TRPV) ion channels in rosacea. J. Invest. Dermatol. 132: 1253-62 [PMID:22189789]

778. Sun M, Goldin E, Stahl S, Falardeau JL, Kennedy JC, Acierno JS, Bove C, Kaneski CR, Nagle J, Bromley MC, Colman M, Schiffmann R and Slaugenhaupt SA. (2000) Mucolipidosis type IV is caused by mutations in a gene encoding a novel transient receptor potential channel. Hum. Mol. Genet. 9: 2471-8 [PMID:11030752] 
779. Sundivakkam PC, Kwiatek AM, Sharma TT, Minshall RD, Malik AB and Tiruppathi C. (2009) Caveolin-1 scaffold domain interacts with TRPC1 and IP3R3 to regulate $\mathrm{Ca} 2+$ store release-induced $\mathrm{Ca} 2+$ entry in endothelial cells. Am. J. Physiol., Cell Physiol. 296: C403-13 [PMID:19052258]

780. Sutton KA, Jungnickel MK, Wang Y, Cullen K, Lambert S and Florman HM. (2004) Enkurin is a novel calmodulin and TRPC channel binding protein in sperm. Dev. Biol. 274: 426-35 [PMID:15385169]

781. Sutton KA, Jungnickel MK, Ward CJ, Harris PC and Florman HM. (2006) Functional characterization of PKDREJ, a male germ cell-restricted polycystin. J. Cell. Physiol. 209: 493-500 [PMID:16883570]

782. Suzuki M, Hirao A and Mizuno A. (2003) Microtubule-associated [corrected] protein 7 increases the membrane expression of transient receptor potential vanilloid 4 (TRPV4). J. Biol. Chem. 278: 51448-53 [PMID:14517216]

783. Suzuki M, Ishibashi K, Ooki G, Tsuruoka S and Imai M. (2000) Electrophysiologic characteristics of the Ca-permeable channels, ECaC and CaT, in the kidney. Biochem. Biophys. Res. Commun. 274: 344-9 [PMID:10913341]

784. Suzuki M, Mizuno A, Kodaira K and Imai M. (2003) Impaired pressure sensation in mice lacking TRPV4J. Biol. Chem. 278: 22664-8 [PMID:12692122]

785. Swanson DM, Dubin AE, Shah C, Nasser N, Chang L, Dax SL, Jetter M, Breitenbucher JG, Liu C and Mazur $C$ et al.. (2005) Identification and biological evaluation of 4-(3-trifluoromethylpyridin-2-yl)piperazine1-carboxylic acid (5-trifluoromethylpyridin-2-yl)amide, a high affinity TRPV1 (VR1) vanilloid receptor antagonist. J. Med. Chem. 48: 1857-72 [PMID:15771431]

786. Szallasi A, Cortright DN, Blum CA and Eid SR. (2007) The vanilloid receptor TRPV1: 10 years from channel cloning to antagonist proof-of-concept. Nat Rev Drug Discov6: 357-72 [PMID:17464295]

787. Tabuchi K, Suzuki M, Mizuno A and Hara A. (2005) Hearing impairment in TRPV4 knockout mice. Neurosci. Lett. 382: 304-8 [PMID:15925108]

788. Takahashi N, Kuwaki T, Kiyonaka S, Numata T, Kozai D, Mizuno Y, Yamamoto S, Naito S, Knevels E and Carmeliet $P$ et al.. (2011) TRPA1 underlies a sensing mechanism for O2. Nat. Chem. Biol. 7: 701-11 [PMID:21873995]

789. Takashima Y, Daniels RL, Knowlton W, Teng J, Liman ER and McKemy DD. (2007) Diversity in the neural circuitry of cold sensing revealed by genetic axonal labeling of transient receptor potential melastatin 8 neurons. J. Neurosci. 27: 14147-57 [PMID:18094254]

790. Takezawa R, Cheng H, Beck A, Ishikawa J, Launay P, Kubota H, Kinet JP, Fleig A, Yamada T and Penner R. (2006) A pyrazole derivative potently inhibits lymphocyte Ca2+ influx and cytokine production by facilitating transient receptor potential melastatin 4 channel activity. Mol. Pharmacol. 69: 1413-20 [PMID:16407466]

791. Takumida M and Anniko M. (2009) Expression of canonical transient receptor potential channel (TRPC) 17 in the mouse inner ear. Acta Otolaryngol. 129: 1351-8 [PMID:19922081]

792. Takumida M, Ishibashi T, Hamamoto T, Hirakawa K and Anniko M. (2009) Expression of transient receptor potential channel melastin (TRPM) 1-8 and TRPA1 (ankyrin) in mouse inner ear. Acta Otolaryngol. 129: 1050-60 [PMID:19065290]

793. Talavera K, Gees M, Karashima Y, Meseguer VM, Vanoirbeek JA, Damann N, Everaerts W, Benoit M, Janssens A and Vennekens R et al.. (2009) Nicotine activates the chemosensory cation channel TRPA1. Nat. Neurosci. 12: 1293-9 [PMID:19749751]

794. Talavera K, Yasumatsu K, Voets T, Droogmans G, Shigemura N, Ninomiya Y, Margolskee RF and Nilius B. (2005) Heat activation of TRPM5 underlies thermal sensitivity of sweet taste. Nature 438: 1022-5 [PMID:16355226]

795. Tamura S, Morikawa Y and Senba E. (2005) TRPV2, a capsaicin receptor homologue, is expressed predominantly in the neurotrophin-3-dependent subpopulation of primary sensory neurons. Neuroscience 130: 223-8 [PMID:15561438]

796. Tang J, Lin Y, Zhang Z, Tikunova S, Birnbaumer L and Zhu MX. (2001) Identification of common binding sites for calmodulin and inositol 1,4,5-trisphosphate receptors on the carboxyl termini of trp channels. $J$. Biol. Chem. 276: 21303-10 [PMID:11290752] 
797. Tang Y, Tang J, Chen Z, Trost C, Flockerzi V, Li M, Ramesh V and Zhu MX. (2000) Association of mammalian trp4 and phospholipase $\mathrm{C}$ isozymes with a PDZ domain-containing protein, NHERF. J. Biol. Chem. 275: 37559-64 [PMID:10980202]

798. Taylor-Clark TE, Ghatta S, Bettner W and Undem BJ. (2009) Nitrooleic acid, an endogenous product of nitrative stress, activates nociceptive sensory nerves via the direct activation of TRPA1. Mol. Pharmacol. 75: 820-9 [PMID:19171673]

799. Taylor-Clark TE and Undem BJ. (2010) Ozone activates airway nerves via the selective stimulation of TRPA1 ion channels. J. Physiol. (Lond.) 588: 423-33 [PMID:20008466]

800. Taylor-Clark TE, Undem BJ, Macglashan Jr DW, Ghatta S, Carr MJ and McAlexander MA. (2008) Prostaglandin-induced activation of nociceptive neurons via direct interaction with transient receptor potential A1 (TRPA1). Mol. Pharmacol. 73: 274-81 [PMID:18000030]

801. Teruyama R, Sakuraba M, Kurotaki H and Armstrong WE. (2011) Transient receptor potential channel m4 and $\mathrm{m} 5$ in magnocellular cells in rat supraoptic and paraventricular nuclei. J. Neuroendocrinol. 23: 1204-13 [PMID:21848647]

802. Thiel G, Müller I and Rössler OG. (2013) Signal transduction via TRPM3 channels in pancreatic $\beta$-cellsJ. Mol. Endocrinol. 50: R75-83 [PMID:23511953]

803. Thiel G, Rubil S, Lesch A, Guethlein LA and Rössler OG. (2017) Transient receptor potential TRPM3 channels: Pharmacology, signaling, and biological functions. Pharmacol. Res. 124: 92-99 [PMID:28720517]

804. Thorneloe KS, Cheung M, Bao W, Alsaid H, Lenhard S, Jian MY, Costell M, Maniscalco-Hauk K, Krawiec JA and Olzinski A et al.. (2012) An orally active TRPV4 channel blocker prevents and resolves pulmonary edema induced by heart failure. Sci Trans/ Med 4: 159ra148 [PMID:23136043]

805. Thorneloe KS, Sulpizio AC, Lin Z, Figueroa DJ, Clouse AK, McCafferty GP, Chendrimada TP, Lashinger ES, Gordon E and Evans L et al.. (2008) N-((1S)-1-\{[4-((2S)-2-\{[(2,4-dichlorophenyl)sulfonyl]amino\}-3hydroxypropanoyl)-1-piperazinyl]carbonyl\}-3-methylbutyl)-1-benzothiophene-2-carboxamide (GSK1016790A), a novel and potent transient receptor potential vanilloid 4 channel agonist induces urinary bladder contraction and hyperactivity: Part I. J. Pharmacol. Exp. Ther. 326: $432-42$ [PMID:18499743]

806. Tian W, Fu Y, Garcia-Elias A, Fernández-Fernández JM, Vicente R, Kramer PL, Klein RF, Hitzemann R, Orwoll ES and Wilmot B et al.. (2009) A loss-of-function nonsynonymous polymorphism in the osmoregulatory TRPV4 gene is associated with human hyponatremia. Proc. Natl. Acad. Sci. U.S.A. 106: 14034-9 [PMID:19666518]

807. Tizzano M, Gulbransen BD, Vandenbeuch A, Clapp TR, Herman JP, Sibhatu HM, Churchill ME, Silver WL, Kinnamon SC and Finger TE. (2010) Nasal chemosensory cells use bitter taste signaling to detect irritants and bacterial signals. Proc. Natl. Acad. Sci. U.S.A. 107: 3210-5 [PMID:20133764]

808. Todaka H, Taniguchi J, Satoh J, Mizuno A and Suzuki M. (2004) Warm temperature-sensitive transient receptor potential vanilloid 4 (TRPV4) plays an essential role in thermal hyperalgesia. J. Biol. Chem. 279: 35133-8 [PMID:15187078]

809. Togashi K, Hara Y, Tominaga T, Higashi T, Konishi Y, Mori Y and Tominaga M. (2006) TRPM2 activation by cyclic ADP-ribose at body temperature is involved in insulin secretion. EMBO J. 25: 1804-15 [PMID:16601673]

810. Togashi K, Inada H and Tominaga M. (2008) Inhibition of the transient receptor potential cation channel TRPM2 by 2-aminoethoxydiphenyl borate (2-APB). Br. J. Pharmacol. 153: 1324-30 [PMID:18204483]

811. Tominaga M, Caterina MJ, Malmberg AB, Rosen TA, Gilbert H, Skinner K, Raumann BE, Basbaum Al and Julius D. (1998) The cloned capsaicin receptor integrates multiple pain-producing stimuli. Neuron 21: 53143 [PMID:9768840]

812. Tong Q, Chu X, Cheung JY, Conrad K, Stahl R, Barber DL, Mignery G and Miller BA. (2004) Erythropoietin-modulated calcium influx through TRPC2 is mediated by phospholipase Cgamma and IP3R. Am. J. Physiol., Cell Physiol. 287: C1667-78 [PMID:15329338]

813. Tong Q, Zhang W, Conrad K, Mostoller K, Cheung JY, Peterson BZ and Miller BA. (2006) Regulation of 
the transient receptor potential channel TRPM2 by the Ca2+ sensor calmodulin. J. Biol. Chem. 281: 907685 [PMID:16461353]

814. Trebak M, Lemonnier L, Smyth JT, Vazquez G and Putney JW. (2007) Phospholipase C-coupled receptors and activation of TRPC channels. Handb Exp Pharmacol 593-614 [PMID:17217081]

815. Trevisan G, Materazzi S, Fusi C, Altomare A, Aldini G, Lodovici M, Patacchini R, Geppetti P and Nassini R. (2013) Novel therapeutic strategy to prevent chemotherapy-induced persistent sensory neuropathy by TRPA1 blockade. Cancer Res. 73: 3120-31 [PMID:23477783]

816. Trevisani M, Siemens J, Materazzi S, Bautista DM, Nassini R, Campi B, Imamachi N, Andrè E, Patacchini $R$ and Cottrell GS et al.. (2007) 4-Hydroxynonenal, an endogenous aldehyde, causes pain and neurogenic inflammation through activation of the irritant receptor TRPA1. Proc. Natl. Acad. Sci. U.S.A. 104: 13519-24 [PMID:17684094]

817. Trevisani M, Smart D, Gunthorpe MJ, Tognetto M, Barbieri M, Campi B, Amadesi S, Gray J, Jerman JC and Brough SJ et al.. (2002) Ethanol elicits and potentiates nociceptor responses via the vanilloid receptor1. Nat. Neurosci. 5: 546-51 [PMID:11992116]

818. Tsavaler L, Shapero MH, Morkowski S and Laus R. (2001) Trp-p8, a novel prostate-specific gene, is upregulated in prostate cancer and other malignancies and shares high homology with transient receptor potential calcium channel proteins. Cancer Res. 61: 3760-9 [PMID:11325849]

819. Tsiokas L, Arnould T, Zhu C, Kim E, Walz G and Sukhatme VP. (1999) Specific association of the gene product of PKD2 with the TRPC1 channel. Proc. Natl. Acad. Sci. U.S.A. 96: 3934-9 [PMID:10097141]

820. Tsiokas L, Kim E, Arnould T, Sukhatme VP and Walz G. (1997) Homo- and heterodimeric interactions between the gene products of PKD1 and PKD2. Proc. Natl. Acad. Sci. U.S.A. 94: 6965-70 [PMID:9192675]

821. Tsutsumi M, Denda S, Ikeyama K, Goto M and Denda M. (2010) Exposure to low temperature induces elevation of intracellular calcium in cultured human keratinocytes. J. Invest. Dermatol. 130: 1945-8 [PMID:20182444]

822. Tsuzuki Y, Sawamoto D, Sakamoto T, Kato T, Niwa Y and Awai N. (2012) Sulfonamide compounds having trpm8 antagonistic activity Patent number: WO2012124825.

823. Tsvilovskyy VV, Zholos AV, Aberle T, Philipp SE, Dietrich A, Zhu MX, Birnbaumer L, Freichel M and Flockerzi V. (2009) Deletion of TRPC4 and TRPC6 in mice impairs smooth muscle contraction and intestinal motility in vivo. Gastroenterology 137: 1415-24 [PMID:19549525]

824. Tympanidis P, Casula MA, Yiangou Y, Terenghi G, Dowd P and Anand P. (2004) Increased vanilloid receptor VR1 innervation in vulvodynia. Eur J Pain 8: 129-33 [PMID:14987622]

825. Tóth B and Csanády L. (2012) Pore collapse underlies irreversible inactivation of TRPM2 cation channel currents. Proc. Natl. Acad. Sci. U.S.A. 109: 13440-5 [PMID:22847436]

826. Tóth B and Csanády L. (2010) Identification of direct and indirect effectors of the transient receptor potential melastatin 2 (TRPM2) cation channel. J. Biol. Chem. 285: 30091-102 [PMID:20650899]

827. Tóth B, lordanov I and Csanády L. (2015) Ruling out pyridine dinucleotides as true TRPM2 channel activators reveals novel direct agonist ADP-ribose-2'-phosphate. J. Gen. Physiol. 145: 419-30 [PMID:25918360]

828. Uemura T, Kudoh J, Noda S, Kanba S and Shimizu N. (2005) Characterization of human and mouse TRPM2 genes: identification of a novel $\mathrm{N}$-terminal truncated protein specifically expressed in human striatum. Biochem. Biophys. Res. Commun. 328: 1232-43 [PMID:15708008]

829. Uhl GR, Walther D, Behm FM and Rose JE. (2011) Menthol preference among smokers: association with TRPA1 variants. Nicotine Tob. Res. 13: 1311-5 [PMID:21719896]

830. Ullrich ND, Voets T, Prenen J, Vennekens R, Talavera K, Droogmans G and Nilius B. (2005) Comparison of functional properties of the Ca2+-activated cation channels TRPM4 and TRPM5 from mice. Cell Calcium 37: 267-78 [PMID:15670874]

831. Vaeth M and Feske S. (2018) Ion channelopathies of the immune system.Curr. Opin. Immunol. 52: 39-50 [PMID:29635109]

832. Valenzano KJ, Grant ER, Wu G, Hachicha M, Schmid L, Tafesse L, Sun Q, Rotshteyn Y, Francis J and Limberis $\mathrm{J}$ et al.. (2003) N-(4-tertiarybutylphenyl)-4-(3-chloropyridin-2-yl)tetrahydropyrazine -1(2H)-carbox- 
amide (BCTC), a novel, orally effective vanilloid receptor 1 antagonist with analgesic properties: I. in vitro characterization and pharmacokinetic properties. J. Pharmacol. Exp. Ther. 306: 377-86 [PMID:12721338]

833. Van Abel M, Hoenderop JG, Dardenne O, St Arnaud R, Van Os CH, Van Leeuwen HJ and Bindels RJ. (2002) 1,25-dihydroxyvitamin $\mathrm{D}$ (3)-independent stimulatory effect of estrogen on the expression of $\mathrm{ECaC} 1$ in the kidney. J. Am. Soc. Nephrol. 13: 2102-9 [PMID:12138142]

834. van Abel M, Hoenderop JG, van der Kemp AW, Friedlaender MM, van Leeuwen JP and Bindels RJ. (2005) Coordinated control of renal $\mathrm{Ca}(2+)$ transport proteins by parathyroid hormone. Kidney Int. 68: 1708-21 [PMID:16164647]

835. Van Cromphaut SJ, Dewerchin M, Hoenderop JG, Stockmans I, Van Herck E, Kato S, Bindels RJ, Collen D, Carmeliet $\mathrm{P}$ and Bouillon $\mathrm{R}$ et al.. (2001) Duodenal calcium absorption in vitamin $\mathrm{D}$ receptor-knockout mice: functional and molecular aspects. Proc. Natl. Acad. Sci. U.S.A. 98: 13324-9 [PMID:11687634]

836. van de Graaf SF, Chang Q, Mensenkamp AR, Hoenderop JG and Bindels RJ. (2006) Direct interaction with Rab11a targets the epithelial Ca2+ channels TRPV5 and TRPV6 to the plasma membrane. Mol. Cell. Biol. 26: 303-12 [PMID:16354700]

837. van de Graaf SF, Hoenderop JG, Gkika D, Lamers D, Prenen J, Rescher U, Gerke V, Staub O, Nilius B and Bindels RJ. (2003) Functional expression of the epithelial $\mathrm{Ca}(2+)$ channels (TRPV5 and TRPV6) requires association of the S100A10-annexin 2 complex. EMBO J. 22: 1478-87 [PMID:12660155]

838. van de Graaf SF, Hoenderop JG, van der Kemp AW, Gisler SM and Bindels RJ. (2006) Interaction of the epithelial Ca2+ channels TRPV5 and TRPV6 with the intestine- and kidney-enriched PDZ protein NHERF4. Pflugers Arch. 452: 407-17 [PMID:16565876]

839. van de Graaf SF, van der Kemp AW, van den Berg D, van Oorschot M, Hoenderop JG and Bindels RJ. (2006) Identification of BSPRY as a novel auxiliary protein inhibiting TRPV5 activity. J. Am. Soc. Nephrol. 17: 26-30 [PMID:16380433]

840. van der Eerden BC, Hoenderop JG, de Vries TJ, Schoenmaker T, Buurman CJ, Uitterlinden AG, Pols HA, Bindels RJ and van Leeuwen JP. (2005) The epithelial Ca2+ channel TRPV5 is essential for proper osteoclastic bone resorption. Proc. Natl. Acad. Sci. U.S.A. 102: 17507-12 [PMID:16291808]

841. van Genderen MM, Bijveld MM, Claassen YB, Florijn RJ, Pearring JN, Meire FM, McCall MA, Riemslag FC, Gregg RG and Bergen AA et al.. (2009) Mutations in TRPM1 are a common cause of complete congenital stationary night blindness. Am. J. Hum. Genet. 85: 730-6 [PMID:19896109]

842. Vannier B, Peyton M, Boulay G, Brown D, Qin N, Jiang M, Zhu X and Birnbaumer L. (1999) Mouse trp2, the homologue of the human trpc2 pseudogene, encodes mTrp2, a store depletion-activated capacitative Ca2+ entry channel. Proc. Natl. Acad. Sci. U.S.A. 96: 2060-4 [PMID:10051594]

843. Veldhuis NA, Poole DP, Grace M, McIntyre P and Bunnett NW. (2015) The G protein-coupled receptortransient receptor potential channel axis: molecular insights for targeting disorders of sensation and inflammation. Pharmacol. Rev. 67: 36-73 [PMID:25361914]

844. Veldhuisen B, Spruit L, Dauwerse HG, Breuning MH and Peters DJ. (1999) Genes homologous to the autosomal dominant polycystic kidney disease genes (PKD1 and PKD2). Eur. J. Hum. Genet. 7: 860-72 [PMID:10602361]

845. Venkatachalam K, Hofmann T and Montell C. (2006) Lysosomal localization of TRPML3 depends on TRPML2 and the mucolipidosis-associated protein TRPML1. J. Biol. Chem. 281: 17517-27 [PMID:16606612]

846. Vennekens R, Hoenderop JG, Prenen J, Stuiver M, Willems PH, Droogmans G, Nilius B and Bindels RJ. (2000) Permeation and gating properties of the novel epithelial $\mathrm{Ca}(2+)$ channel. J. Biol. Chem. 275: 3963-9 [PMID:10660551]

847. Vennekens R and Nilius B. (2007) Insights into TRPM4 function, regulation and physiological role.Handb Exp Pharmacol 269-85 [PMID:17217063]

848. Vennekens R, Olausson J, Meissner M, Bloch W, Mathar I, Philipp SE, Schmitz F, Weissgerber P, Nilius B and Flockerzi $V$ et al.. (2007) Increased IgE-dependent mast cell activation and anaphylactic responses in mice lacking the calcium-activated nonselective cation channel TRPM4. Nat. Immunol. 8: 312-20 [PMID:17293867] 
849. Vennekens R, Owsianik G and Nilius B. (2008) Vanilloid transient receptor potential cation channels: an overview. Curr. Pharm. Des. 14: 18-31 [PMID:18220815]

850. Vennekens R, Prenen J, Hoenderop JG, Bindels RJ, Droogmans G and Nilius B. (2001) Modulation of the epithelial Ca2+ channel ECaC by extracellular pH. Pflugers Arch. 442: 237-42 [PMID:11417220]

851. Venugopal B, Mesires NT, Kennedy JC, Curcio-Morelli C, Laplante JM, Dice JF and Slaugenhaupt SA. (2009) Chaperone-mediated autophagy is defective in mucolipidosis type IV. J. Cell. Physiol. 219: 344-53 [PMID:19117012]

852. Vergarajauregui S, Connelly PS, Daniels MP and Puertollano R. (2008) Autophagic dysfunction in mucolipidosis type IV patients. Hum. Mol. Genet. 17: 2723-37 [PMID:18550655]

853. Vergarajauregui S, Martina JA and Puertollano R. (2011) LAPTMs regulate lysosomal function and interact with mucolipin 1: new clues for understanding mucolipidosis type IV. J. Cell. Sci. 124: 459-68 [PMID:21224396]

854. Vergarajauregui S, Martina JA and Puertollano R. (2009) Identification of the penta-EF-hand protein ALG2 as a Ca2+-dependent interactor of mucolipin-1. J. Biol. Chem. 284: 36357-66 [PMID:19864416]

855. Vilceanu D and Stucky CL. (2010) TRPA1 mediates mechanical currents in the plasma membrane of mouse sensory neurons. PLoS ONE 5: e12177 [PMID:20808441]

856. Vincent F, Acevedo A, Nguyen MT, Dourado M, DeFalco J, Gustafson A, Spiro P, Emerling DE, Kelly MG and Duncton MA. (2009) Identification and characterization of novel TRPV4 modulators. Biochem.

Biophys. Res. Commun. 389: 490-4 [PMID:19737537]

857. Viribay M, Hayashi T, Tellería D, Mochizuki T, Reynolds DM, Alonso R, Lens XM, Moreno F, Harris PC and Somlo $S$ et al.. (1997) Novel stop and frameshifting mutations in the autosomal dominant polycystic kidney disease 2 (PKD2) gene. Hum. Genet. 101: 229-34 [PMID:9402976]

858. Viswanath V, Story GM, Peier AM, Petrus MJ, Lee VM, Hwang SW, Patapoutian A and Jegla T. (2003) Opposite thermosensor in fruitfly and mouse. Nature 423: 822-3 [PMID:12815418]

859. Voets T, Droogmans G, Wissenbach U, Janssens A, Flockerzi V and Nilius B. (2004) The principle of temperature-dependent gating in cold- and heat-sensitive TRP channels. Nature 430: 748-54 [PMID:15306801]

860. Voets T, Janssens A, Droogmans G and Nilius B. (2004) Outer pore architecture of a Ca2+-selective TRP channel. J. Biol. Chem. 279: 15223-30 [PMID:14736889]

861. Voets T, Janssens A, Prenen J, Droogmans G and Nilius B. (2003) Mg2+-dependent gating and strong inward rectification of the cation channel TRPV6. J. Gen. Physiol. 121: 245-60 [PMID:12601087]

862. Voets T and Nilius B. (2007) Modulation of TRPs by PIPs.J. Physiol. (Lond.) 582: 939-44 [PMID:17395625]

863. Voets T, Nilius B, Hoefs S, van der Kemp AW, Droogmans G, Bindels RJ and Hoenderop JG. (2004) TRPM6 forms the Mg2+ influx channel involved in intestinal and renal Mg2+ absorption. J. Biol. Chem. 279: 19-25 [PMID:14576148]

864. Voets T, Owsianik G and Nilius B. (2007) TRPM8.Handb Exp Pharmaco/ 329-44 [PMID:17217067]

865. Voets T, Prenen J, Fleig A, Vennekens R, Watanabe H, Hoenderop JG, Bindels RJ, Droogmans G, Penner $R$ and Nilius B. (2001) CaT1 and the calcium release-activated calcium channel manifest distinct pore properties. J. Biol. Chem. 276: 47767-70 [PMID:11687570]

866. Voets $T$, Prenen J, Vriens J, Watanabe H, Janssens A, Wissenbach U, Bödding M, Droogmans $G$ and Nilius B. (2002) Molecular determinants of permeation through the cation channel TRPV4. J. Biol. Chem. 277: 33704-10 [PMID:12093812]

867. Vogt-Eisele AK, Weber K, Sherkheli MA, Vielhaber G, Panten J, Gisselmann G and Hatt H. (2007) Monoterpenoid agonists of TRPV3. Br. J. Pharmacol. 151: 530-40 [PMID:17420775]

868. Vriens J, Appendino G and Nilius B. (2009) Pharmacology of vanilloid transient receptor potential cation channels. Mol. Pharmacol. 75: 1262-79 [PMID:19297520]

869. Vriens J, Held K, Janssens A, Tóth BI, Kerselaers S, Nilius B, Vennekens R and Voets T. (2014) Opening of an alternative ion permeation pathway in a nociceptor TRP channel. Nat. Chem. Biol. 10: 188-95 [PMID:24390427] 
870. Vriens J, Owsianik G, Hofmann T, Philipp SE, Stab J, Chen X, Benoit M, Xue F, Janssens A and Kerselaers $S$ et al.. (2011) TRPM3 is a nociceptor channel involved in the detection of noxious heat. Neuron 70: 482-94 [PMID:21555074]

871. Wagner SA, Beli P, Weinert BT, Nielsen ML, Cox J, Mann M and Choudhary C. (2011) A proteome-wide, quantitative survey of in vivo ubiquitylation sites reveals widespread regulatory roles. Mol. Cell Proteomics 10: M111.013284 [PMID:21890473]

872. Wagner TF, Loch S, Lambert S, Straub I, Mannebach S, Mathar I, Düfer M, Lis A, Flockerzi V and Philipp SE et al.. (2008) Transient receptor potential M3 channels are ionotropic steroid receptors in pancreatic beta cells. Nat. Cell Biol. 10: 1421-30 [PMID:18978782]

873. Wahl P, Foged C, Tullin S and Thomsen C. (2001) lodo-resiniferatoxin, a new potent vanilloid receptor antagonist. Mol. Pharmacol. 59: 9-15 [PMID:11125018]

874. Walder RY, Landau D, Meyer P, Shalev H, Tsolia M, Borochowitz Z, Boettger MB, Beck GE, Englehardt RK and Carmi R et al.. (2002) Mutation of TRPM6 causes familial hypomagnesemia with secondary hypocalcemia. Nat. Genet. 31: 171-4 [PMID:12032570]

875. Walker RL, Koh SD, Sergeant GP, Sanders KM and Horowitz B. (2002) TRPC4 currents have properties similar to the pacemaker current in interstitial cells of Cajal. Am. J. Physiol., Cell Physiol. 283: C1637-45 [PMID:12388058]

876. Wang HL, Katon J, Balan C, Bannon AW, Bernard C, Doherty EM, Dominguez C, Gavva NR, Gore V and Ma $V$ et al.. (2007) Novel vanilloid receptor-1 antagonists: 3. The identification of a second-generation clinical candidate with improved physicochemical and pharmacokinetic properties. J. Med. Chem. 50: 3528-39 [PMID:17585751]

877. Wang W, O'Connell B, Dykeman R, Sakai T, Delporte C, Swaim W, Zhu X, Birnbaumer L and Ambudkar IS. (1999) Cloning of Trp1beta isoform from rat brain: immunodetection and localization of the endogenous Trp1 protein. Am. J. Physiol. 276: C969-79 [PMID:10199829]

878. Wang X, Zhang X, Dong XP, Samie M, Li X, Cheng X, Goschka A, Shen D, Zhou Y and Harlow \&t al.. (2012) TPC proteins are phosphoinositide- activated sodium-selective ion channels in endosomes and lysosomes. Cell 151: 372-83 [PMID:23063126]

879. Wang Y, Bu J, Shen H, Li H, Wang Z and Chen G. (2017) Targeting Transient Receptor Potential Canonical Channels for Diseases of the Nervous System. Curr Drug Targets 18: 1460-1465 [PMID:26648074]

880. Wang Y, Fu X, Gaiser S, Köttgen M, Kramer-Zucker A, Walz G and Wegierski T. (2007) OS-9 regulates the transit and polyubiquitination of TRPV4 in the endoplasmic reticulum. J. Biol. Chem. 282: 36561-70 [PMID:17932042]

881. Wang Y, Szabo T, Welter JD, Toth A, Tran R, Lee J, Kang SU, Suh YG, Blumberg PM and Lee J. (2002) High affinity antagonists of the vanilloid receptor. Mol. Pharmacol. 62: 947-56 [PMID:12237342]

882. Wang YY, Chang RB, Allgood SD, Silver WL and Liman ER. (2011) A TRPA1-dependent mechanism for the pungent sensation of weak acids. J. Gen. Physiol. 137: 493-505 [PMID:21576376]

883. Wang YY, Chang RB and Liman ER. (2010) TRPA1 is a component of the nociceptive response to CO2. J. Neurosci. 30: 12958-63 [PMID:20881114]

884. Watanabe H, Davis JB, Smart D, Jerman JC, Smith GD, Hayes P, Vriens J, Cairns W, Wissenbach U and Prenen J et al.. (2002) Activation of TRPV4 channels (hVRL-2/mTRP12) by phorbol derivatives.J. Biol. Chem. 277: 13569-77 [PMID:11827975]

885. Watanabe H, Vriens J, Prenen J, Droogmans G, Voets T and Nilius B. (2003) Anandamide and arachidonic acid use epoxyeicosatrienoic acids to activate TRPV4 channels. Nature 424: 434-8 [PMID:12879072]

886. Watanabe H, Vriens J, Suh SH, Benham CD, Droogmans G and Nilius B. (2002) Heat-evoked activation of TRPV4 channels in a HEK293 cell expression system and in native mouse aorta endothelial cells. $J$. Biol. Chem. 277: 47044-51 [PMID:12354759]

887. Weber K, Erben RG, Rump A and Adamski J. (2001) Gene structure and regulation of the murine epithelial calcium channels ECaC1 and 2. Biochem. Biophys. Res. Commun. 289: 1287-94 
[PMID:11741335]

888. Weber KS, Hildner K, Murphy KM and Allen PM. (2010) Trpm4 differentially regulates Th1 and Th2 function by altering calcium signaling and NFAT localization. J. Immunol. 185: 2836-46 [PMID:20656926]

889. Wehage E, Eisfeld J, Heiner I, Jüngling E, Zitt C and Lückhoff A. (2002) Activation of the cation channel long transient receptor potential channel 2 (LTRPC2) by hydrogen peroxide. A splice variant reveals a mode of activation independent of ADP-ribose. J. Biol. Chem. 277: 23150-6 [PMID:11960981]

890. Wehrhahn J, Kraft R, Harteneck $C$ and Hauschildt S. (2010) Transient receptor potential melastatin 2 is required for lipopolysaccharide-induced cytokine production in human monocytes. J. Immunol. 184: 238693 [PMID:20107186]

891. Wei C, Wang X, Chen M, Ouyang K, Song LS and Cheng H. (2009) Calcium flickers steer cell migration. Nature 457: $901-5$ [PMID:19118385]

892. Wei H, Hämäläinen MM, Saarnilehto M, Koivisto A and Pertovaara A. (2009) Attenuation of mechanical hypersensitivity by an antagonist of the TRPA1 ion channel in diabetic animals. Anesthesiology 111: 14754 [PMID:19512877]

893. Weissgerber P, Kriebs U, Tsvilovskyy V, Olausson J, Kretz O, Stoerger C, Mannebach S, Wissenbach U, Vennekens $R$ and Middendorff $R$ et al.. (2012) Excision of Trpv6 gene leads to severe defects in epididymal $\mathrm{Ca} 2+$ absorption and male fertility much like single D541A pore mutation. J. Biol. Chem. 287: 17930-41 [PMID:22427671]

894. Weissgerber P, Kriebs U, Tsvilovskyy V, Olausson J, Kretz O, Stoerger C, Vennekens R, Wissenbach U, Middendorff $\mathrm{R}$ and Flockerzi $\mathrm{V}$ et al.. (2011) Male fertility depends on $\mathrm{Ca} \leq+$ absorption by TRPV 6 in epididymal epithelia. Sci Signal 4: ra27 [PMID:21540454]

895. Weissmann N, Sydykov A, Kalwa H, Storch U, Fuchs B, Mederos y Schnitzler M, Brandes RP, Grimminger F, Meissner M and Freichel $M$ et al.. (2012) Activation of TRPC6 channels is essential for lung ischaemiareperfusion induced oedema in mice. Nat Commun 3: 649 [PMID:22337127]

896. Wescott SA, Rauthan M and Xu XZ. (2013) When a TRP goes bad: transient receptor potential channels in addiction. Life Sci. 92: 410-4 [PMID:22820171]

897. Willette RN, Bao W, Nerurkar S, Yue TL, Doe CP, Stankus G, Turner GH, Ju H, Thomas H and Fishman CE et al.. (2008) Systemic activation of the transient receptor potential vanilloid subtype 4 channel causes endothelial failure and circulatory collapse: Part 2. J. Pharmacol. Exp. Ther. 326: 443-52 [PMID:18499744]

898. Wilson SR, Gerhold KA, Bifolck-Fisher A, Liu Q, Patel KN, Dong X and Bautista DM. (2011) TRPA1 is required for histamine-independent, Mas-related $G$ protein-coupled receptor-mediated itch. Nat. Neurosci. 14: 595-602 [PMID:21460831]

899. Wilson SR, Nelson AM, Batia L, Morita T, Estandian D, Owens DM, Lumpkin EA and Bautista DM. (2013) The ion channel TRPA1 is required for chronic itch. J. Neurosci. 33: 9283-94 [PMID:23719797]

900. Winn MP, Conlon PJ, Lynn KL, Farrington MK, Creazzo T, Hawkins AF, Daskalakis N, Kwan SY, Ebersviller S and Burchette JL et al.. (2005) A mutation in the TRPC6 cation channel causes familial focal segmental glomerulosclerosis. Science 308: 1801-4 [PMID:15879175]

901. Wissenbach U and Niemeyer BA. (2007) TRPV6. Handb Exp Pharmacol 221-34 [PMID:17217060]

902. Wissenbach U, Niemeyer BA, Fixemer T, Schneidewind A, Trost C, Cavalie A, Reus K, Meese E, Bonkhoff $\mathrm{H}$ and Flockerzi V. (2001) Expression of CaT-like, a novel calcium-selective channel, correlates with the malignancy of prostate cancer. J. Biol. Chem. 276: 19461-8 [PMID:11278579]

903. Wistow G, Bernstein SL, Ray S, Wyatt MK, Behal A, Touchman JW, Bouffard G, Smith D and Peterson K. (2002) Expressed sequence tag analysis of adult human iris for the NEIBank Project: steroid-response factors and similarities with retinal pigment epithelium. Mol. Vis. 8: 185-95 [PMID:12107412]

904. Wistow G, Bernstein SL, Wyatt MK, Fariss RN, Behal A, Touchman JW, Bouffard G, Smith D and Peterson K. (2002) Expressed sequence tag analysis of human RPE/choroid for the NEIBank Project: over 6000 non-redundant transcripts, novel genes and splice variants. Mol. Vis. 8: 205-20 [PMID:12107410]

905. Witzgall R. (2007) TRPP2 channel regulation. Handb Exp Pharmacol 363-75 [PMID:17217069]

906. Wodicka LM, Ciceri P, Davis MI, Hunt JP, Floyd M, Salerno S, Hua XH, Ford JM, Armstrong RC and Zarrinkar PP et al.. (2010) Activation state-dependent binding of small molecule kinase inhibitors: structural 
insights from biochemistry. Chem. Biol. 17: 1241-9 [PMID:21095574]

907. Wong CO, Huang Y and Yao X. (2010) Genistein potentiates activity of the cation channel TRPC5 independently of tyrosine kinases. Br. J. Pharmacol. 159: 1486-96 [PMID:20233211]

908. Woo SK, Kwon MS, Ivanov A, Gerzanich V and Simard JM. (2013) The sulfonylurea receptor 1 (Sur1)transient receptor potential melastatin 4 (Trpm4) channel. J. Biol. Chem. 288: 3655-67 [PMID:23255597]

909. Wu G, D'Agati V, Cai Y, Markowitz G, Park JH, Reynolds DM, Maeda Y, Le TC, Hou Jr H and Kucherlapati $R$ et al.. (1998) Somatic inactivation of Pkd2 results in polycystic kidney disease.Cell 93: 177-88 [PMID:9568711]

910. Wu G, Hayashi T, Park JH, Dixit M, Reynolds DM, Li L, Maeda Y, Cai Y, Coca-Prados M and Somlo S. (1998) Identification of PKD2L, a human PKD2-related gene: tissue-specific expression and mapping to chromosome 10q25. Genomics 54: 564-8 [PMID:9878261]

911. Wu G, Markowitz GS, Li L, D'Agati VD, Factor SM, Geng L, Tibara S, Tuchman J, Cai Y and Park Jłt al.. (2000) Cardiac defects and renal failure in mice with targeted mutations in Pkd2. Nat. Genet. 24: 75-8 [PMID:10615132]

912. Wu G, Mochizuki T, Le TC, Cai Y, Hayashi T, Reynolds DM and Somlo S. (1997) Molecular cloning, cDNA sequence analysis, and chromosomal localization of mouse Pkd2. Genomics 45: 220-3 [PMID:9339380]

913. Wu G, Tian X, Nishimura S, Markowitz GS, D'Agati V, Park JH, Yao L, Li L, Geng L and Zhao Het al.. (2002) Trans-heterozygous Pkd1 and Pkd2 mutations modify expression of polycystic kidney disease. Hum. Mol. Genet. 11: 1845-54 [PMID:12140187]

914. Wu L, Gao X, Brown RC, Heller S and O'Neil RG. (2007) Dual role of the TRPV4 channel as a sensor of flow and osmolality in renal epithelial cells. Am. J. Physiol. Renal Physiol. 293: F1699-713 [PMID:17699550]

915. Wu LJ, Sweet TB and Clapham DE. (2010) International Union of Basic and Clinical Pharmacology. LXXVI. Current progress in the mammalian TRP ion channel family. Pharmacol. Rev. 62: 381-404 [PMID:20716668]

916. Wu X, Eder P, Chang B and Molkentin JD. (2010) TRPC channels are necessary mediators of pathologic cardiac hypertrophy. Proc. Natl. Acad. Sci. U.S.A. 107: 7000-5 [PMID:20351294]

917. Xenophontos S, Constantinides R, Hayashi T, Mochizuki T, Somlo S, Pierides A and Deltas CC. (1997) A translation frameshift mutation induced by a cytosine insertion in the polycystic kidney disease 2 gene (PDK2). Hum. Mol. Genet. 6: 949-52 [PMID:9175744]

918. Xiao B, Dubin AE, Bursulaya B, Viswanath V, Jegla TJ and Patapoutian A. (2008) Identification of transmembrane domain 5 as a critical molecular determinant of menthol sensitivity in mammalian TRPA1 channels. J. Neurosci. 28: 9640-51 [PMID:18815250]

919. Xiao R, Tang J, Wang C, Colton CK, Tian J and Zhu MX. (2008) Calcium plays a central role in the sensitization of TRPV3 channel to repetitive stimulations. J. Biol. Chem. 283: 6162-74 [PMID:18178557]

920. Xu C, Macciardi F, Li PP, Yoon IS, Cooke RG, Hughes B, Parikh SV, McIntyre RS, Kennedy JL and Warsh JJ. (2006) Association of the putative susceptibility gene, transient receptor potential protein melastatin type 2, with bipolar disorder. Am. J. Med. Genet. B Neuropsychiatr. Genet. 141B: 36-43 [PMID:16252251]

921. Xu F, Satoh E and lijima T. (2003) Protein kinase C-mediated Ca2+ entry in HEK 293 cells transiently expressing human TRPV4. Br. J. Pharmacol. 140: 413-21 [PMID:12970074]

922. Xu H, Blair NT and Clapham DE. (2005) Camphor activates and strongly desensitizes the transient receptor potential vanilloid subtype 1 channel in a vanilloid-independent mechanism. J. Neurosci. 25: 892437 [PMID:16192383]

923. Xu H, Delling M, Jun JC and Clapham DE. (2006) Oregano, thyme and clove-derived flavors and skin sensitizers activate specific TRP channels. Nat. Neurosci. 9: 628-35 [PMID:16617338]

924. Xu H, Delling M, Li L, Dong X and Clapham DE. (2007) Activating mutation in a mucolipin transient receptor potential channel leads to melanocyte loss in varitint-waddler mice. Proc. Natl. Acad. Sci. U.S.A. 104: 18321-6 [PMID:17989217]

925. Xu H, Ramsey IS, Kotecha SA, Moran MM, Chong JA, Lawson D, Ge P, Lilly J, Silos-Santiago I and Xie Y 
et al.. (2002) TRPV3 is a calcium-permeable temperature-sensitive cation channel. Nature 418: 181-6 [PMID:12077604]

926. Xu H and Ren D. (2015) Lysosomal physiology.Annu. Rev. Physiol. 77: 57-80 [PMID:25668017]

927. Xu H, Zhao H, Tian W, Yoshida K, Roullet JB and Cohen DM. (2003) Regulation of a transient receptor potential (TRP) channel by tyrosine phosphorylation. SRC family kinase-dependent tyrosine phosphorylation of TRPV4 on TYR-253 mediates its response to hypotonic stress. J. Biol. Chem. 278: 11520-7 [PMID:12538589]

928. Xu SZ, Zeng F, Boulay G, Grimm C, Harteneck C and Beech DJ. (2005) Block of TRPC5 channels by 2aminoethoxydiphenyl borate: a differential, extracellular and voltage-dependent effect. Br. J. Pharmacol. 145: 405-14 [PMID:15806115]

929. Xu XZ, Moebius F, Gill DL and Montell C. (2001) Regulation of melastatin, a TRP-related protein, through interaction with a cytoplasmic isoform. Proc. Natl. Acad. Sci. U.S.A. 98: 10692-7 [PMID:11535825]

930. Xue T, Do MT, Riccio A, Jiang Z, Hsieh J, Wang HC, Merbs SL, Welsbie DS, Yoshioka T and Weissgerber $P$ et al.. (2011) Melanopsin signalling in mammalian iris and retina.Nature 479: 67-73 [PMID:22051675]

931. Yamada T, Ueda T, Shibata Y, Ikegami Y, Saito M, Ishida Y, Ugawa S, Kohri K and Shimada S. (2010) TRPV2 activation induces apoptotic cell death in human T24 bladder cancer cells: a potential therapeutic target for bladder cancer. Urology 76: 509.e1-7 [PMID:20546877]

932. Yamaguchi H, Matsushita M, Nairn AC and Kuriyan J. (2001) Crystal structure of the atypical protein kinase domain of a TRP channel with phosphotransferase activity. Mol. Cell 7: 1047-57 [PMID:11389851]

933. Yamaguchi S, Jha A, Li Q, Soyombo AA, Dickinson GD, Churamani D, Brailoiu E, Patel S and Muallem S. (2011) Transient receptor potential mucolipin 1 (TRPML1) and two-pore channels are functionally independent organellar ion channels. J. Biol. Chem. 286: 22934-42 [PMID:21540176]

934. Yamamoto S, Shimizu S, Kiyonaka S, Takahashi N, Wajima T, Hara Y, Negoro T, Hiroi T, Kiuchi Y and Okada T et al.. (2008) TRPM2-mediated Ca2+influx induces chemokine production in monocytes that aggravates inflammatory neutrophil infiltration. Nat. Med. 14: 738-47 [PMID:18542050]

935. Yamamoto S, Takahashi N and Mori Y. (2010) Chemical physiology of oxidative stress-activated TRPM2 and TRPC5 channels. Prog. Biophys. Mol. Biol. 103: 18-27 [PMID:20553742]

936. Yamashiro K, Sasano T, Tojo K, Namekata I, Kurokawa J, Sawada N, Suganami T, Kamei Y, Tanaka H and Tajima N et al.. (2010) Role of transient receptor potential vanilloid 2 in LPS-induced cytokine production in macrophages. Biochem. Biophys. Res. Commun. 398: 284-9 [PMID:20599720]

937. Yang J, Li Y, Zuo X, Zhen Y, Yu Y and Gao L. (2008) Transient receptor potential ankyrin-1 participates in visceral hyperalgesia following experimental colitis. Neurosci. Lett. 440: 237-41 [PMID:18583045]

938. Yang KT, Chang WL, Yang PC, Chien CL, Lai MS, Su MJ and Wu ML. (2006) Activation of the transient receptor potential M2 channel and poly(ADP-ribose) polymerase is involved in oxidative stress-induced cardiomyocyte death. Cell Death Differ. 13: 1815-26 [PMID:16294211]

939. Yang W, Manna PT, Zou J, Luo J, Beech DJ, Sivaprasadarao A and Jiang LH. (2011) Zinc inactivates melastatin transient receptor potential 2 channels via the outer pore. J. Biol. Chem. 286: 23789-98 [PMID:21602277]

940. Yang W, Zou J, Xia R, Vaal ML, Seymour VA, Luo J, Beech DJ and Jiang LH. (2010) State-dependent inhibition of TRPM2 channel by acidic pH. J. Biol. Chem. 285: 30411-8 [PMID:20660597]

941. Yao X and Garland CJ. (2005) Recent developments in vascular endothelial cell transient receptor potential channels. Circ. Res. 97: 853-63 [PMID:16254217]

942. Yap KL, Kim J, Truong K, Sherman M, Yuan T and lkura M. (2000) Calmodulin target database J. Struct. Funct. Genomics 1: 8-14 [PMID:12836676]

943. Ye L, Kleiner S, Wu J, Sah R, Gupta RK, Banks AS, Cohen P, Khandekar MJ, Boström P and Mepani RJ et al.. (2012) TRPV4 is a regulator of adipose oxidative metabolism, inflammation, and energy homeostasis. Cell 151: 96-110 [PMID:23021218]

944. Yeh BI, Kim YK, Jabbar W and Huang CL. (2005) Conformational changes of pore helix coupled to gating of TRPV5 by protons. EMBO J. 24: 3224-34 [PMID:16121193]

945. Yeh BI, Sun TJ, Lee JZ, Chen HH and Huang CL. (2003) Mechanism and molecular determinant for 
regulation of rabbit transient receptor potential type 5 (TRPV5) channel by extracellular pH. J. Biol. Chem. 278: 51044-52 [PMID:14525991]

946. Yiangou Y, Facer P, Dyer NH, Chan CL, Knowles C, Williams NS and Anand P. (2001) Vanilloid receptor 1 immunoreactivity in inflamed human bowel. Lancet 357: 1338-9 [PMID:11343743]

947. Yildirim E, Dietrich A and Birnbaumer L. (2003) The mouse C-type transient receptor potential 2 (TRPC2) channel: alternative splicing and calmodulin binding to its $\mathrm{N}$ terminus. Proc. Natl. Acad. Sci. U.S.A. 100: 2220-5 [PMID:12601176]

948. Yin Y, Wu M, Zubcevic L, Borschel WF, Lander GC and Lee SY. (2018) Structure of the cold- and menthol-sensing ion channel TRPM8. Science 359: 237-241 [PMID:29217583]

949. Yoon IS, Li PP, Siu KP, Kennedy JL, Macciardi F, Cooke RG, Parikh SV and Warsh JJ. (2001) Altered TRPC7 gene expression in bipolar-I disorder. Biol. Psychiatry 50: 620-6 [PMID:11690598]

950. Yoshida T, Inoue R, Morii T, Takahashi N, Yamamoto S, Hara Y, Tominaga M, Shimizu S, Sato Y and Mori Y. (2006) Nitric oxide activates TRP channels by cysteine S-nitrosylation. Nat. Chem. Biol. 2: 596-607 [PMID:16998480]

951. Yu CR. (2015) TRICK or TRP? What Trpc2(-/-) mice tell us about vomeronasal organ mediated innate behaviors. Front Neurosci 9: 221 [PMID:26157356]

952. Yu L, Jin W, Wang JX, Zhang X, Chen MM, Zhu ZH, Lee H, Lee M and Zhang YP. (2010) Characterization of TRPC2, an essential genetic component of VNS chemoreception, provides insights into the evolution of pheromonal olfaction in secondary-adapted marine mammals. Mol. Biol. Evol. 27: 1467-77 [PMID:20142439]

953. Yu W, Hill WG, Apodaca G and Zeidel ML. (2011) Expression and distribution of transient receptor potential (TRP) channels in bladder epithelium. Am. J. Physiol. Renal Physiol. 300: F49-59 [PMID:20943764]

954. Yuan JP, Kim MS, Zeng W, Shin DM, Huang G, Worley PF and Muallem S. (2009) TRPC channels as STIM1-regulated SOCs. Channels (Austin) 3: 221-5 [PMID:19574740]

955. Yuan JP, Kiselyov K, Shin DM, Chen J, Shcheynikov N, Kang SH, Dehoff MH, Schwarz MK, Seeburg PH and Muallem $S$ et al.. (2003) Homer binds TRPC family channels and is required for gating of TRPC1 by IP3 receptors. Cell 114: 777-89 [PMID:14505576]

956. Yuan JP, Zeng W, Dorwart MR, Choi YJ, Worley PF and Muallem S. (2009) SOAR and the polybasic STIM1 domains gate and regulate Orai channels. Nat. Cell Biol. 11: 337-43 [PMID:19182790]

957. Yuan JP, Zeng W, Huang GN, Worley PF and Muallem S. (2007) STIM1 heteromultimerizes TRPC channels to determine their function as store-operated channels. Nat. Cell Biol. 9: 636-45 [PMID:17486119]

958. Yue L, Peng JB, Hediger MA and Clapham DE. (2001) CaT1 manifests the pore properties of the calciumrelease-activated calcium channel. Nature 410: 705-9 [PMID:11287959]

959. Zagranichnaya TK, Wu X and Villereal ML. (2005) Endogenous TRPC1, TRPC3, and TRPC7 proteins combine to form native store-operated channels in HEK-293 cells. J. Biol. Chem. 280: 29559-69 [PMID:15972814]

960. Zaika O, Mamenko M, Berrout J, Boukelmoune N, O'Neil RG and Pochynyuk O. (2013) TRPV4 dysfunction promotes renal cystogenesis in autosomal recessive polycystic kidney disease. J. Am. Soc. Nephrol.24: 604-16 [PMID:23411787]

961. Zakharian E, Thyagarajan B, French RJ, Pavlov E and Rohacs T. (2009) Inorganic polyphosphate modulates TRPM8 channels. PLoS ONE 4: e5404 [PMID:19404398]

962. Zanou N, Iwata Y, Schakman O, Lebacq J, Wakabayashi S and Gailly P. (2009) Essential role of TRPV2 ion channel in the sensitivity of dystrophic muscle to eccentric contractions. FEBS Lett. 583: 3600-4 [PMID:19840792]

963. Zechel S, Werner S and von Bohlen Und Halbach O. (2007) Distribution of TRPC4 in developing and adult murine brain. Cell Tissue Res. 328: 651-6 [PMID:17345099]

964. Zeevi DA, Frumkin A and Bach G. (2007) TRPML and lysosomal function.Biochim. Biophys. Acta 1772: 851-8 [PMID:17306511] 
965. Zeevi DA, Lev S, Frumkin A, Minke B and Bach G. (2010) Heteromultimeric TRPML channel assemblies play a crucial role in the regulation of cell viability models and starvation-induced autophagy. J. Cell. Sci. 123: 3112-24 [PMID:20736310]

966. Zhang DX, Mendoza SA, Bubolz AH, Mizuno A, Ge ZD, Li R, Warltier DC, Suzuki M and Gutterman DD. (2009) Transient receptor potential vanilloid type 4-deficient mice exhibit impaired endothelium-dependent relaxation induced by acetylcholine in vitro and in vivo. Hypertension 53: 532-8 [PMID:19188524]

967. Zhang E and Liao P. (2015) Brain transient receptor potential channels and stroke J. Neurosci. Res. 93: 1165-83 [PMID:25502473]

968. Zhang P, Luo Y, Chasan B, González-Perrett S, Montalbetti N, Timpanaro GA, Cantero Mdel R, Ramos AJ, Goldmann WH and Zhou J et al.. (2009) The multimeric structure of polycystin-2 (TRPP2): structuralfunctional correlates of homo- and hetero-multimers with TRPC1. Hum. Mol. Genet. 18: 1238-51 [PMID:19193631]

969. Zhang W, Chu X, Tong Q, Cheung JY, Conrad K, Masker K and Miller BA. (2003) A novel TRPM2 isoform inhibits calcium influx and susceptibility to cell death. J. Biol. Chem. 278: 16222-9 [PMID:12594222]

970. Zhang W, Hirschler-Laszkiewicz I, Tong Q, Conrad K, Sun SC, Penn L, Barber DL, Stahl R, Carey DJ and Cheung JY et al.. (2006) TRPM2 is an ion channel that modulates hematopoietic cell death through activation of caspases and PARP cleavage. Am. J. Physiol., Cell Physiol. 290: C1146-59 [PMID:16306129]

971. Zhang X, Li L and McNaughton PA. (2008) Proinflammatory mediators modulate the heat-activated ion channel TRPV1 via the scaffolding protein AKAP79/150. Neuron 59: 450-61 [PMID:18701070]

972. Zhang $\mathrm{X}$, Li X and $\mathrm{Xu} \mathrm{H}$. (2012) Phosphoinositide isoforms determine compartment-specific ion channel activity. Proc. Natl. Acad. Sci. U.S.A. 109: 11384-9 [PMID:22733759]

973. Zhang X, Mak S, Li L, Parra A, Denlinger B, Belmonte C and McNaughton PA. (2012) Direct inhibition of the cold-activated TRPM8 ion channel by Gaq. Nat. Cell Biol. 14: 851-8 [PMID:22750945]

974. Zhang Y, Hoon MA, Chandrashekar J, Mueller KL, Cook B, Wu D, Zuker CS and Ryba NJ. (2003) Coding of sweet, bitter, and umami tastes: different receptor cells sharing similar signaling pathways. Cell 112: 293-301 [PMID:12581520]

975. Zhang Z, Okawa H, Wang Y and Liman ER. (2005) Phosphatidylinositol 4,5-bisphosphate rescues TRPM4 channels from desensitization. J. Biol. Chem. 280: 39185-92 [PMID:16186107]

976. Zhang Z, Zhao Z, Margolskee R and Liman E. (2007) The transduction channel TRPM5 is gated by intracellular calcium in taste cells. J. Neurosci. 27: 5777-86 [PMID:17522321]

977. Zhiqi S, Soltani MH, Bhat KM, Sangha N, Fang D, Hunter JJ and Setaluri V. (2004) Human melastatin 1 (TRPM1) is regulated by MITF and produces multiple polypeptide isoforms in melanocytes and melanoma. Melanoma Res. 14: 509-16 [PMID:15577322]

978. Zholos A. (2010) Pharmacology of transient receptor potential melastatin channels in the vasculatureBr. J. Pharmacol. 159: 1559-71 [PMID:20233227]

979. Zhu MX. (2011) Various TRP Channels (CRC Press/Taylor \& Francis) [PMID:22593967]

980. Zhu X, Jiang M, Peyton M, Boulay G, Hurst R, Stefani E and Birnbaumer L. (1996) trp, a novel mammalian gene family essential for agonist-activated capacitative Ca2+ entry. Cell 85: 661-71 [PMID:8646775]

981. Zhuang L, Peng JB, Tou L, Takanaga H, Adam RM, Hediger MA and Freeman MR. (2002) Calciumselective ion channel, CaT1, is apically localized in gastrointestinal tract epithelia and is aberrantly expressed in human malignancies. Lab. Invest. 82: 1755-64 [PMID:12480925]

982. Zielińska M, Jarmuż A, Wasilewski A, Sałaga M and Fichna J. (2015) Role of transient receptor potential channels in intestinal inflammation and visceral pain: novel targets in inflammatory bowel diseases. Inflamm. Bowel Dis. 21: 419-27 [PMID:25437822]

983. Zierler S, Yao G, Zhang Z, Kuo WC, Pörzgen P, Penner R, Horgen FD and Fleig A. (2011) Waixenicin A inhibits cell proliferation through magnesium-dependent block of transient receptor potential melastatin 7 (TRPM7) channels. J. Biol. Chem. 286: 39328-35 [PMID:21926172]

984. Zimmermann K, Lennerz JK, Hein A, Link AS, Kaczmarek JS, Delling M, Uysal S, Pfeifer JD, Riccio A and Clapham DE. (2011) Transient receptor potential cation channel, subfamily C, member 5 (TRPC5) is a cold-transducer in the peripheral nervous system. Proc. Natl. Acad. Sci. U.S.A. 108: 18114-9 
[PMID:22025699]

985. Zitt C, Obukhov AG, Strübing C, Zobel A, Kalkbrenner F, Lückhoff A and Schultz G. (1997) Expression of TRPC3 in Chinese hamster ovary cells results in calcium-activated cation currents not related to store depletion. J. Cell Biol. 138: 1333-41 [PMID:9298988]

986. Zitt C, Zobel A, Obukhov AG, Harteneck C, Kalkbrenner F, Lückhoff A and Schultz G. (1996) Cloning and functional expression of a human $\mathrm{Ca2}+$-permeable cation channel activated by calcium store depletion. Neuron 16: 1189-96 [PMID:8663995]

987. Zubcevic, L., Le, S., Yang, H., Lee and S.Y.. (2018) Conformational Plasticity in the Selectivity Filter of the TRPV2 Ion Channel Nat.Struct.Mol.Biol.

988. Zufall F, Ukhanov K, Lucas P, Liman ER and Leinders-Zufall T. (2005) Neurobiology of TRPC2: from gene to behavior. Pflugers Arch. 451: 61-71 [PMID:15971083]

989. Zygmunt PM, Petersson J, Andersson DA, Chuang H, Sørgård M, Di Marzo V, Julius D and Högestätt ED. (1999) Vanilloid receptors on sensory nerves mediate the vasodilator action of anandamide. Nature $\mathbf{4 0 0}$ 452-7 [PMID:10440374] 